\title{
A review of taxonomy and flower-breeding ecology of the Colocasiomyia toshiokai species group (Diptera: Drosophilidae), with description of a new species from Indonesia
}

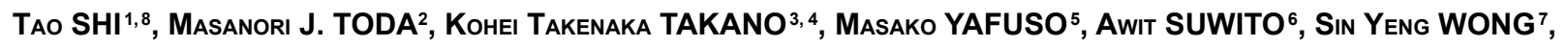
SU-QIN SHANG ${ }^{8, *}$ and JIAN-JUN GAO ${ }^{1,9, *}$

${ }^{1}$ Yunnan Key Laboratory of Plant Reproductive Adaptation and Evolutionary Ecology, Yunnan University, Kunming, China; e-mails: 502970289@163.com, gaojj@ynu.edu.cn

${ }^{2}$ Hokkaido University Museum, Hokkaido University, N10 W8, Kita-ku, Sapporo 060-0810, Japan;

e-mail: hutian@lemon.plala.or.jp

${ }^{3}$ Graduate School of Environmental Earth Science, Hokkaido University, N10 W5, Kita-ku, Sapporo 060-0810, Japan

${ }^{4}$ Nagano Environmental Conservation Research Institute, Kitago 2054-120, Nagano 381-0075, Japan; e-mail:

takano-kohei-r@pref.nagano.lg.jp

${ }^{5}$ Uema 1-2-21, Naha, Okinawa 902-0073, Japan; e-mail: yafusom@juno.ocn.ne.jp

${ }^{6}$ Zoology Division (Museum Zoologicum Bogoriense), Research Center for Biology-LIPI, JI, Raya Jakarta-Bogor Km. 46, Cibinong 16911, West Java, Indonesia; e-mail: awitswt@yahoo.com

${ }^{7}$ Faculty of Resource Science and Technology, Universiti Malaysia Sarawak, 94300 Kota Samarahan, Sarawak, Malaysia; e-mail: sywong@unimas.my

${ }^{8}$ Department of Entomology, College of Grassland Science, Gansu Agricultural University, Lanzhou, China; e-mail: suqinsh@126.com

${ }^{9}$ Laboratory of Ecology and Evolutionary Biology, State Key Laboratory for Conservation and Utilization of Bioresources in Yunnan, Yunnan University, Kunming, China

Key words. Diptera, Drosophilidae, Colocasiomyia toshiokai species group, DNA barcoding, species delimitation, taxonomy, Araceae, Homalomena, Aglaonema, flower-breeding ecology, Malaysia, Indonesia

\begin{abstract}
Flies of the Colocasiomyia toshiokai species group depend exclusively on inflorescences/infructescences of the aroid tribe Homalomeneae. The taxonomy and reproductive biology of this group is reviewed on the basis of data and samples collected from Southeast Asia. The species boundaries are determined by combining morphological analyses and molecular species delimitation based on sequences of the mitochondrial $\mathrm{COI}$ (cytochrome $c$ oxidase subunit I) gene. For the phylogenetic classification within this species group, a cladistic analysis of all the member species is conducted based on 29 parsimony-informative, morphological characters. As a result, six species are recognised within the toshiokai group, including one new species, viz. C. toshiokai, C. xanthogaster, C. nigricauda, C. erythrocephala, C. heterodonta and C. rostrata sp. $\mathrm{n}$. Various host plants are utilised by these species in different combinations at different localities: Some host plants are monopolized by a single species, while others are shared by two or three species. C. xanthogaster and C. heterodonta cohabit on the same host plant in West Java, breeding on spatially different parts of the spadix. There is a close synchrony between flower-visiting behaviour of flies and flowering events of host plants, which indicate an intimate pollination mutualism.
\end{abstract}

ZooBank Article LSID: EB6FDBBC-7696-440A-A214-22912537D9F3

\section{INTRODUCTION}

Flies of the family Drosophilidae principally feed/breed on fermenting or decaying organic matter such as fruit, tree sap, mushrooms and herbage (Kimura et al., 1977; Shorrocks, 1982). However, feeding on fresh flowers has evolved repeatedly in some lineages of Drosophilidae
(Brncic, 1983). The genus Colocasiomyia de Meijere is one such group that obligatorily breeds in flowers. Currently there are 29 formally described species in this genus, mostly from the Asian tropics (Toda, 2018), which are classified into six species groups (Sultana et al., 2006; Fartyal et al., 2013). Each species group specialises on host plants

\footnotetext{
* Corresponding authors; e-mails: suqinsh@126.com, gaojj@ynu.edu.cn
} 
of a particular taxon (Yafuso \& Okada, 1990; Yafuso et al., 2000; Sultana et al., 2002, 2006; Toda \& Lakim, 2011; Fartyal et al., 2013; Li et al., 2014): crassipes group (Sultana et al., 2006) the family Magnoliaceae, zylanica group (Sultana et al., 2006) the family Arecaceae (genus Pinanga Blume), gigantea group (Fartyal et al., 2013) the subfamily Monsteroideae (Araceae), baechlii group (Okada, 1990) the tribe Schismatoglottideae (subfamily Aroideae, Araceae), cristata group (Okada, 1990) the Colocasia clade and genera Alocasia (Schott) G. Don and Leucocasia (sensu Cusimano et al., 2011; Aroideae, Araceae), and toshiokai group (Sultana et al., 2002) the genera Homalomena Schott (Philodendron clade) and Aglaonema Schott (tribe Aglaonemateae) of Aroideae (Araceae).

Colocasiomyia flies depend on specific host plants throughout their entire life cycle; their life histories from oviposition to adult eclosion are adapted to the flowering/ fruiting of specific host plants, and vary depending on the number and combination of cohabiting fly species (Carson \& Okada, 1980; Honda-Yafuso, 1983; Toda \& Okada, 1983; Yafuso, 1994; Takenaka, 2006; Takenaka et al., 2006; Takano et al., 2012; Fartyal et al., 2013). In turn, the flies serve as specific, obligate pollinators of their host plants (Yafuso, 1993; Miyake \& Yafuso, 2003; Takenaka, 2006; Takenaka et al., 2006; Takano et al., 2012).

The toshiokai group was established by Sultana et al. (2002) for five species: C. toshiokai (Okada, 1983) recorded from the Philippines, C. xanthogaster Yafuso \& Okada, 1990 and C. heterodonta Yafuso \& Okada, 1990 both from Java, C. erythrocephala Sultana \& Yafuso, 2002 from Vietnam and C. nigricauda Sultana \& Toda, 2002 from Sabah. All these species are recorded exclusively on inflorescences of the genera Homalomena and Aglaonema. However, the knowledge of their flower-visiting/breeding habits is still fragmentary (Yafuso \& Okada, 1990).

In addition, Sultana et al. (2006) lists four undescribed, putative species (sp. aff. heterodonta from Java, sp. 2 aff. heterodonta and sp. 3 aff. heterodonta from Sumatra, and sp. aff. xanthogaster from Sumatra and Sulawesi) as members of the toshiokai group, but leave their species status uncertain. In the present study, the species delimitation and relationships within the toshiokai group are determined based on detailed morphology and mitochondrial COI (cytochrome $c$ oxidase subunit I) sequences of populations from Malaysia and Indonesia. As a result, one new species is described and the descriptions of the five known species are revised. In addition, the reproductive ecology of this species group is summarized on the basis of all the available data and observations of flower-visiting behaviour in relation to heat generation by host plant inflorescences.

\section{MATERIAL AND METHODS}

\section{Insect specimens}

All of the specimens included in the present study were collected from inflorescences of Homalomena and Aglaonema in Malaysia and Indonesia (see the "Ecological observation" section for details). Specimens were preserved in Kahle's solution followed by $70 \%$ ethanol for morphological observation, or in $100 \%$ ethanol for DNA sequencing.
The specimens studied are deposited in the following institutions: Forest Research Center, Kuching, Sarawak, Malaysia (FRCK); Kinabalu Park, Sabah Parks, Sabah, Malaysia (KPSP); Institute for Tropical Biology and Conservation, Universiti Malaysia Sabah, Kota Kinabalu, Sabah, Malaysia (BORN); Museum Zoologicum Bogoriense, Bogor, Indonesia (MZB); Systematic Entomology, The Hokkaido University Museum, Hokkaido University, Sapporo, Japan (SEHU); Tsukuba Research Departments of National Museum of Nature and Science Tokyo, Japan (NSMT); and Kunming Natural History Museum of Zoology, Kunming Institute of Zoology, Chinese Academy of Sciences, Kunming, China (KIZ).

\section{Species delimitation and description}

We followed the same methods used by Sultana et al. (2002) and $\mathrm{Li}$ et al. (2014) for studying their external morphology, measuring and dissecting them. First, the intact whole body was observed under a stereoscopic microscope for determining the external morphology and measuring characters using an ocular micrometer. Then, the head, mouthparts, a foreleg and male/female terminalia were detached from the body of some specimens, treated with $10 \% \mathrm{KOH}$ solution at $80-90^{\circ} \mathrm{C}$ for a few minutes and mounted in a droplet of glycerin on a cavity slide to observe under a light microscope. The fine structures of these dissected organs were microphotographed (either following further dissection or not) using a DinoLite ${ }^{\circledR}$ Digital Eyepiece Camera or a HITACHI TM3000 tabletop scanning electron microscope (SEM), and drawn based on the resulting digital pictures using CORELDRAW $^{\circledR}$ X4 (Corel Corporation).

The specimens were first identified as members of the C. toshiokai group and sorted into known and putatively new species based on their morphology. Then, a total of 38 specimens representing local populations of these morpho-species were selected for sequencing a 658-bp fragment of COI (Table S1). However, DNA was not available for two species, C. toshiokai and C. erythrocephala. Some DNA samples were extracted from whole bodies following the method of Boom et al. (1990), with some modifications (Kobayashi et al., 2009). The remaining DNA samples were extracted from a hindleg or small piece(s) of abdominal tissue extracted through the hole left after the removal of the terminalia, using the TIANamp ${ }^{\circledR}$ Genomic DNA Kit. We used the same methods for PCR and sequencing as in Li et al. (2014), with Folmer et al.'s (1994) primers: LCO1490, 5'- GGTCA ACAAA TCATA AAGAT ATTG G -3'; HCO2198, 5'- TAAAC TTCAG GGTGA CCAAA AAATC A -3', and an ABI $^{\circledR} 3730$ DNA Analyzer. Sequences were edited in the SEQMAN module of the DNASTAR package (DNASTAR Inc. 1996) and aligned in MEGA7 (Kumar et al., 2016).

For the species delimitation based on molecular data, the COI sequences were analysed using three algorithms for OTU (Operational Taxonomic Unit) recognition: the Automatic Barcode Gap Discovery (ABGD; Puillandre et al., 2012), the Generalized Mixed Yule Coalescent (GMYC; Pons et al., 2006) and the Refined Single Linkage (RESL; Ratnasingham \& Hebert, 2013). The ABGD analysis was done using the web interface (http://wwwabi.snv. jussieu.fr/public/abgd/abgdweb.html). The COI alignments were uploaded to this web-interface, and analysed under the default setting: $P$ (prior maximum divergence of intraspecific diversity) ranges from 0.001 to 0.1 ; Steps $=10 ; X$ (a proxy for minimum gap width $)=1.5$; $\mathrm{Nb}$ bins (for distance distribution $)=20$; distance $=$ Jukes-Cantor (JC69). For the GMYC analysis, an ultrametric tree was generated by BEAST v2.4.5 (Bouckaert et al., 2014) using the Yule prior and the HKY (Hasegawa et al., 1985) + Gamma model. The MCMC chains were run for 5,000,000 generations with a burn-in of the initial $10 \%$ of samples, then the output was 
summarized using TreeAnotator v2.4.8. The GMYC analysis was performed using the package "splits" (Species Limits by Threshold Statistics; available from http://r-forge.r-project.org/projects/ splits) implemented in R software with default scaling parameters for the single- and multiple-threshold options. Ratnasingham \& Hebert (2013) developed the Barcode Index Number (BIN) System within the Barcode of Life Data System (BOLD: http://www. barcodinglife.org; Ratnasingham \& Hebert, 2007) to register the OTUs (hypothetical species) delineated by RESL. New barcode sequences uploaded to BOLD are analysed through the BIN pipeline (Ratnasingham \& Hebert, 2013); the BIN assignments of all records in BOLD are updated regularly, and BIN clusters can be split further or merged together. We used BIN assignments for our $C O I$ sequences as the results of RESL analysis, which were downloaded from BOLD on May 28, 2018. A maximum likelihood (ML) tree was constructed using the program RAxML HPC (Stamatakis, 2006). In the ML analysis, the data set of the COI sequences was partitioned into two: $1 \mathrm{st}+2$ nd codon positions and 3rd codon position. We selected eight species, two from each of four other species groups, as outgroup taxa (Table S1). A total of 100 distinct ML trees were calculated starting from distinct random trees under the GTRGAMMA model of nucleotide substitution, with the gamma model of rate heterogeneity across sites. Branch confidence values (bootstrap percentages, BPs) were obtained by conducting rapid bootstrap analyses (1000 replicates), with bipartitions drawn from the 1000 boot strapped trees onto the best-scoring ML tree of the 100 calculated.

The species boundaries were determined integratively based on the results of the above molecular analyses and morphological comparison. In the description of a new species and redescriptions of known species, we followed McAlpine (1981) for the morphological terminology and Zhang \& Toda (1992) for the definitions of measurements and indices.

\section{Cladistic analysis of morphological characters}

In order to determine the phylogenetic positions of C. toshiokai and $C$. erythrocephala, for which no specimens were available for DNA sequencing, a cladistic analysis of all six species of the toshiokai group was conducted using morphological characters. Four outgroup taxa, C. baechlii (Okada, 1986), C. sp. 1 aff. bogneri, $C$. sp. 2 aff. bogneri and $C$. sp. 13 aff. bogneri, were selected from the baechlii group, which was proposed as the sister to the toshiokai group because of some synapomorphies and partial overlap in their host plant use with the toshiokai group (Sultana et al., 2006).

For the character selection, we examined the detailed structure of every sclerotised organ of adult males and females. In addition to the characters investigated previously (Sultana et al., 2002, 2006; Fartyal et al., 2013), a number of new ones were compared among the six species of the toshiokai group. The character states for C. baechlii are based on its original description (Okada, 1986).

The parsimony analysis was performed using PAUP* v4.0a165 (Swofford, 2003). Maximum parsimony cladogram was generated by a heuristic search with 1000 replicates under the setting of "addition sequences at random" and "tree-bisection reconnection (TBR)" branch-swapping. All transformation series were assumed to be "unordered". On the resulting tree, character optimization was performed by ACCTRAN (accelerated transformation) and DELTRAN (delayed transformation). Branch support was assessed by a bootstrap analysis with 1000 replicates.

\section{Ecological observations}

In order to investigate the flower-visiting and reproductive habits of the species of the toshiokai group, field collections and observations were conducted at various localities in Vietnam,
Malaysia (Sarawak and Sabah) and Indonesia (Sumatra, Java and Sulawesi). At each locality, host plant (Homalomena and Aglaonema) inflorescences/infructescences at different developmental stages were collected. The flowering/fruiting of host inflorescences/infructescences was divided into six stages (Fig. 1B): Stage I, inflorescence bud with spadix completely covered with spathe before anthesis; Stage II, flowering phase with spathe open and spadix exposed; Stage III, post-flowering phase with spathe closed and spadix covered; Stage IV, stamens decaying and pistils starting to grow within spathe; Stage V, stamen-remnants dried out and fruit growing; Stage VI, spathe dehisced and ripe fruitlets exposed. When Colocasiomyia flies were found visiting an inflorescence at Stage II, the inflorescence was enclosed within a plastic bag and all adult insects coming out of the inflorescence within the plastic bag were caught using an aspirator. The collected inflorescences/infructescences were brought back to the laboratory and dissected under a stereomicrocope to determine the distribution of Colocasiomyia immature stages (eggs, larvae or puparia) on the spadix. In cases where C. xanthogaster and $C$. heterodonta coexisted, their immatures were identified based on the morphological differences described for eggs and larvae

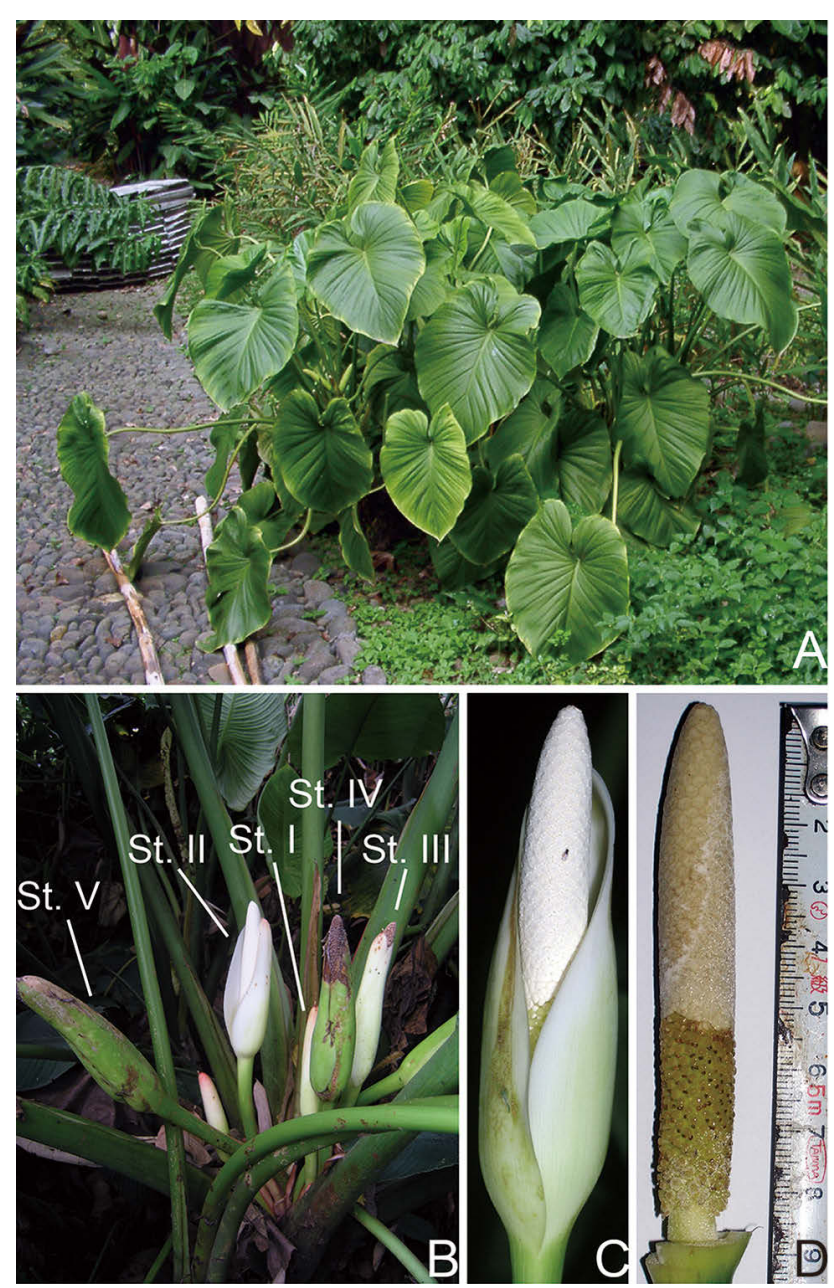

Fig. 1. Homalomena megalophylla M. Hotta in West Java. A - photograph of a complete plant; B - inflorescences and infructescences at Stages I to V (see text for explanation of each stage) in a cluster of sequentially blooming inflorescences; C - an inflorescence at Stage II, with a Colocasiomyia fly on the spadix; D - a spadix with powdery pollen at Stage III, shown by removing the spathe: upper $3 / 5$ of the spadix, the staminate region covered with male flowers (stamens); lower $2 / 5$, the pistillate region covered with female flowers (pistils). 


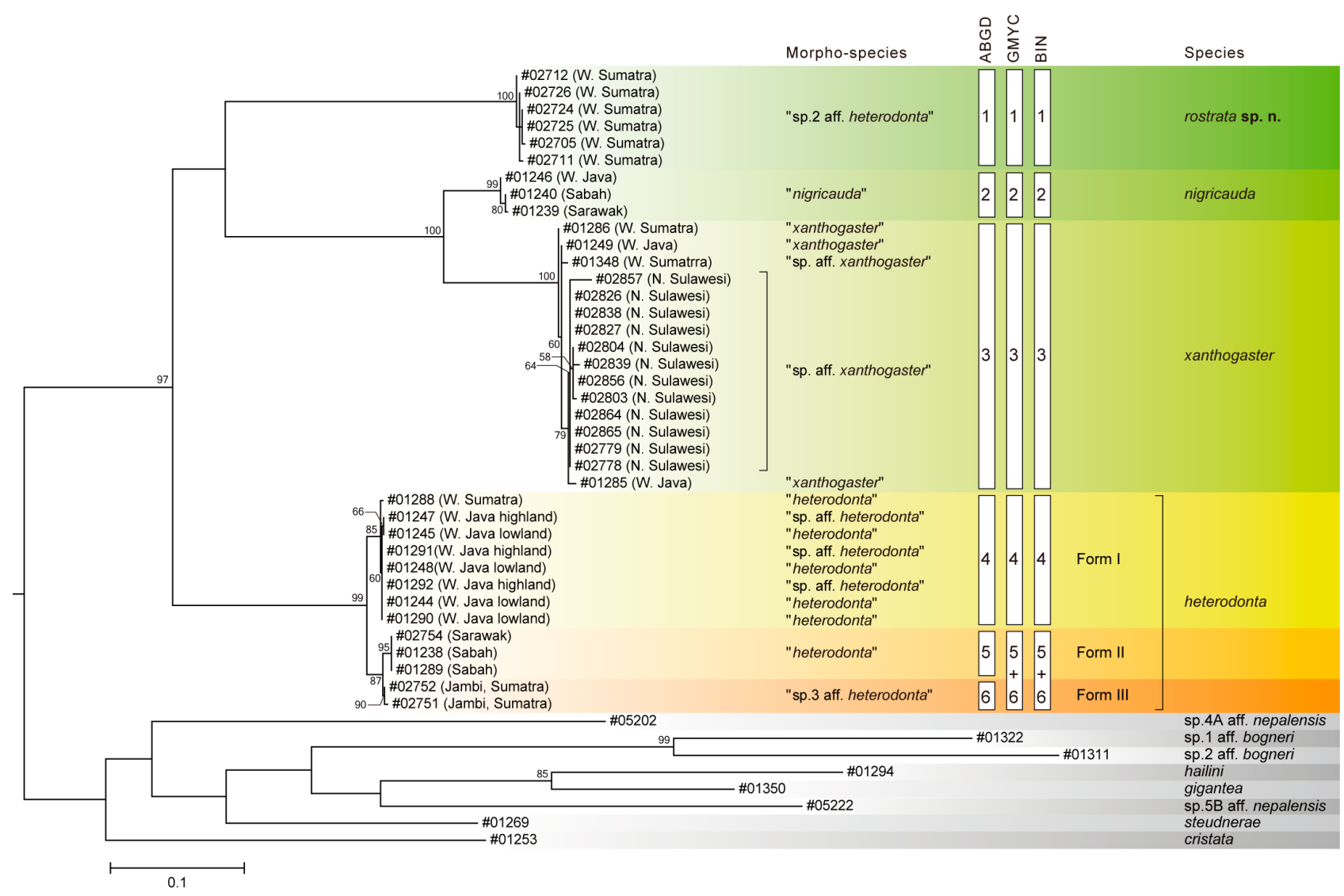

Fig. 2. ML phylogenetic tree of the Colocasiomyia toshiokai species group, based on 658-bp COI sequences and rooted with outgroup species. Label of each sequence is in the format of a "specimen voucher number (region of collection locality)". Numbers beside branches are bootstrap percentages (>50\%). Open bars indicate OTUs (Operational Taxonomic Units; hypothetical species) inferred from the ABGD analysis (recursive partitions at $P=0.0017$ to 0.0046 ; see Table S2 for details), the GMYC analysis, and BIN assignments.

of these two species by Yafuso \& Okada (1990). The distribution of C. nigricauda immatures was examined on inflorescences/ infructescences of Homalomena lambirensis S.Y. Wong \& P.C. Boyce in Lambir, Sarawak, where C. nigricauda monopolized this host plant. No inflorescences/infructescences were examined for immature distributions of the other Colocasiomyia species.

Flower-visiting behaviour of Colocasiomyia flies during the flowering of two host plants belonging to the Homalomena supergroup, Homalomena megalophylla M. Hotta (Fig. 1) and $H$. pendula (Blume) Bakh. f. (Fig. S4), was observed in the Bogor Botanical Garden $\left(6^{\circ} 35^{\prime} \mathrm{S}, 106^{\circ} 47^{\prime} \mathrm{E}, 260 \mathrm{~m}\right.$ a.s.l., West Java, Indonesia), from November 14 to 17, 2009 for H. megalophylla and from August 1 to 4, 2011 for H. pendula. Important flowering events, i.e., anthesis, heat generation, odour emission, pollen release and spathe closure, were observed on one inflorescence of each species. Inflorescences of $H$. megalophylla and $H$. pendula are nearly identical in structure. The spadix consists of a pistillate (lower female-flower) region covered with pistils and clavate, interpistillar staminodes, and a staminate (upper maleflower) region covered with stamens (Fig. 1D). There are two or three lines of relatively large, closely spaced staminodes at the border between the pistillate and staminate regions. The spathe covers the spadix and forms a spathal chamber (Fig. 1C). Temperatures of the pistillate and the staminate regions were measured by inserting two thermo-couple sensors into the middle part of the respective regions through the spathe from the rear side. These temperatures were recorded along with nearby ambient temperature, every $2 \mathrm{~min}$ for 3 days covering the entire flowering process, using a data logger thermometer $\left(\right.$ Center $\left.^{\mathbb{B}} 309\right)$. At the same time, the behaviour of insects visiting the inflorescences, particularly that of Colocasiomyia, was recorded.

\section{RESULTS AND DISCUSSION}

\section{Species delimitation}

Fig. 2 shows the ML tree constructed using the $C O I$ sequences, along with the results of the ABGD and GMYC analyses and the BIN assignments. The monophyly of the toshiokai group was strongly supported $(\mathrm{BP}=97)$. The 38 ingroup sequences were sorted into six OTUs by the ABGD analysis (see also Table S2). Each OTU represented a highly supported clade with $\mathrm{BP} \geq 85$. OTU1 $(\mathrm{BP}=100)$ and OTU2 (BP = 99) each corresponded to a single morphospecies, "sp. 2 aff. heterodonta" and "nigricauda", respectively. OTU3 (BP = 100) included two morpho-species, "xanthogaster" from West Java (including the type locality of C. xanthogaster, Bogor) and West Sumatra and the dark form "sp. aff. xanthogaster" from West Sumatra and North Sulawesi. The sister relationship between OTU2 and OTU3 was strongly supported $(\mathrm{BP}=100)$. The remaining three OTUs formed another highly supported cluster $(\mathrm{BP}=$ 99). Of the three OTUs, OTU6 $(\mathrm{BP}=90)$ corresponded to the morpho-species "sp. 3 aff. heterodonta" representing a highland population on Mt. Kerinci, Jambi, Sumatra. Another morpho-species, "sp. aff. heterodonta", which was recognised for highland populations with darker body col- 


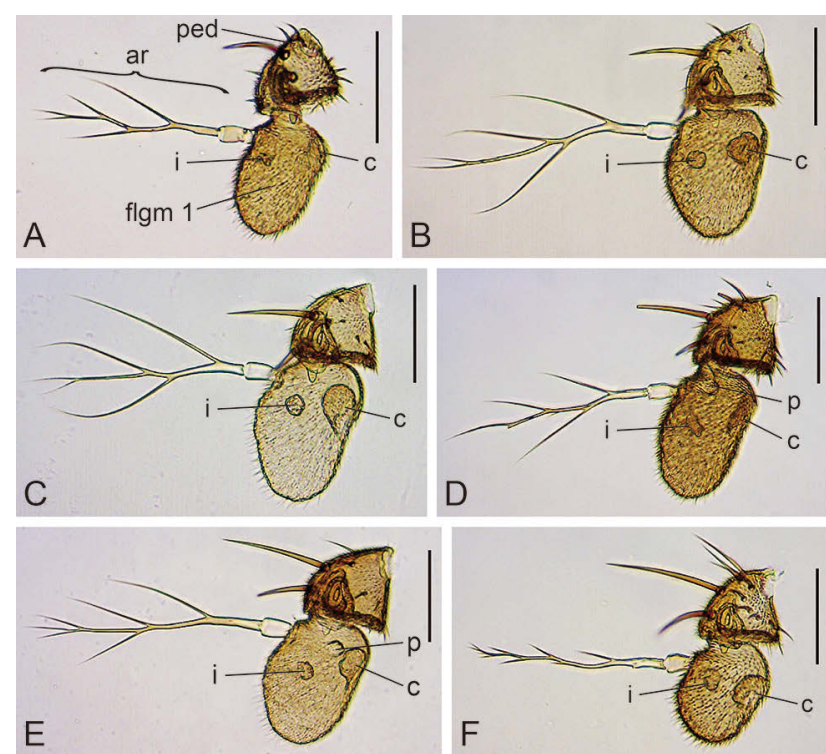

Fig. 3. Right antenna (inner-lateral view) of the Colocasiomyia toshiokai species group. A - C. toshiokai (paratype from the Philippines); B - C. xanthogaster ( $\delta$ from the type locality, i.e., Bogor Botanical Garden, Bogor, West Java, Indonesia); C - C. nigricauda ( $ठ$ from Inobong, Crocker Range, Sabah, Malaysia); D C. erythrocephala (paratype $\delta$ from Vietnam); E - C. heterodonta ( $\delta$ from the type locality, i.e., Bogor Botanical Garden, Bogor, West Java, Indonesia); F - C. rostrata sp. n. (paratype $\delta$ from Lembah Anai, West Sumatra, Indonesia). Abbreviations: ar - arista, c-cavity, flgm 1 - first flagellomere, $i$ - invaginated organ, $p$ - pouch, ped - pedicel. Scale bars: $0.1 \mathrm{~mm}$.

our in West Java, was assigned to OTU4 $(\mathrm{BP}=85)$, together with populations of "heterodonta" in lowland West Java (including the type locality of $C$. heterodonta, Bogor) and Sumatra. However, the Bornean (Sabah and Sarawak) populations that had been identified as $C$. heterodonta (Sultana et al., 2002, 2006; Toda \& Lakim, 2011) formed OTU5 $(\mathrm{BP}=95)$ distinct from OTU4. However, the GMYC and BIN assignments lumped OTU5 and OTU6. Morphologically, the three OTUs of the "heterodonta" cluster were more or less different from each other (see Remarks for $C$. heterodonta). Especially, OTU6 was quite different in the morphology of its phallic organs from OTU4 and OTU5 (Fig. S2E, F, K, L, P, Q), suggesting that OTU6 is a distinct species. However, the molecular evidence contradicts the
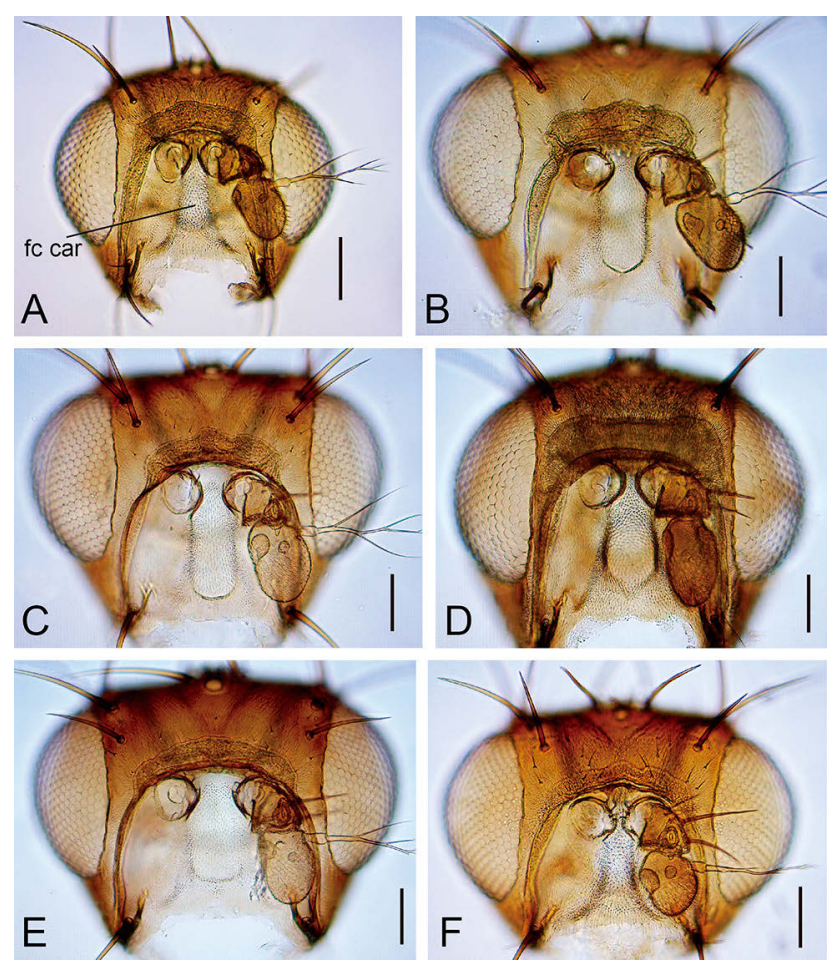

Fig. 4. Head (frontal view) of the Colocasiomyia toshiokai species group. A - C. toshiokai; B - C. xanthogaster; C - C. nigricauda; D - C. erythrocephala; E - C. heterodonta; F - C. rostrata sp. $n$. The photographed specimens are the same as those in Fig. 3. Abbreviations: fc car - facial carina. Scale bars: $0.1 \mathrm{~mm}$.

morphological resemblance: OTU5 and OTU6 were more similar in their $C O I$ sequences. A more critical point for the molecular species delimitation in this cluster is the insufficient sampling of OTU5 and OTU6 with only three and two specimens included in the analyses, respectively. Therefore, we refrained from taking any formal nomenclatural actions regarding the OTUs in this cluster and treated them as different forms of $C$. heterodonta: OTU4 $=$ Form I (including the type of $C$. heterodonta), OTU5 = Form II (populations from Sarawak and Sabah, Borneo), and OTU6 = Form III (a highland population on Mt. Kerinci, Sumatra). As a consequence, we recognised four (one new and three known) species within the studied samples of the $C$. toshiokai species group: OTU1 $=C$. rostrata Shi

Table 1. Data matrix of 29 morphological characters of six species of the Colocasiomyia toshiokai species group (ingroup) and four species of the $C$. baechlii species group (outgroup). Character descriptions and polarity are fully detailed in the text (Cladistic analysis section).

\begin{tabular}{|c|c|c|c|c|c|c|c|c|c|c|c|c|c|c|c|c|c|c|c|c|c|c|c|c|c|c|c|c|c|}
\hline Character No. & 1 & 2 & 3 & 4 & 5 & 6 & 7 & 8 & 9 & 10 & 11 & 12 & 13 & 14 & 15 & 16 & 17 & 18 & 19 & 20 & 21 & 22 & 23 & 24 & 25 & 26 & 27 & 28 & 29 \\
\hline \multicolumn{30}{|l|}{ Outgroup } \\
\hline C. sp. 1 aff. bogneri & 0 & 0 & 0 & 0 & 0 & 0 & 0 & 0 & 0 & 0 & 0 & 0 & 0 & 0 & 0 & 0 & 0 & ? & 0 & 0 & 0 & 0 & 0 & 0 & 0 & 0 & 0 & 0 & 0 \\
\hline C. sp. 2 aff. bogneri & 0 & 0 & 0 & 0 & 0 & 0 & 0 & 0 & 0 & 0 & 0 & 0 & 2 & 2 & 0 & 0 & 0 & ? & 0 & 0 & 0 & 0 & 0 & 0 & 0 & 0 & 0 & 0 & 0 \\
\hline C. baechlii & ? & ? & ? & ? & 0 & ? & $?$ & ? & ? & ? & 0 & 0 & 0 & 2 & 0 & 0 & 0 & ? & 0 & 0 & 0 & 0 & 0 & 0 & ? & ? & ? & 1 & ? \\
\hline C. sp. 1 & 0 & 0 & 1 & 0 & 1 & 0 & 0 & 1 & 0 & 1 & 1 & 1 & 1 & 0 & 0 & 0 & 0 & $?$ & 0 & 0 & 0 & 0 & 1 & 0 & 0 & 1 & 0 & 2 & 0 \\
\hline \multicolumn{30}{|l|}{ Ingroup } \\
\hline C. rostrata s & 0 & 0 & 1 & 1 & 0 & 0 & 0 & 0 & 1 & 0 & 1 & 0 & 3 & 2 & 0 & 0 & 2 & 0 & 1 & 1 & 0 & 1 & 1 & 1 & 0 & 0 & 1 & 0 & 1 \\
\hline C. heterodonta & 1 & 1 & 1 & 0 & 1 & 0 & 2 & 1 & 1 & 0 & 0 & 0 & 0 & 0 & 0 & 1 & 2 & 1 & 1 & 2 & 0 & b & 1 & 1 & 0 & a & 0 & 1 & 0 \\
\hline C. erythrocephala & 1 & 1 & 1 & 1 & 1 & 0 & 2 & 1 & 1 & 1 & 0 & 0 & 1 & 1 & 1 & 1 & 2 & 1 & 1 & 1 & 0 & 1 & 1 & 1 & 1 & 1 & 0 & 0 & 1 \\
\hline C. toshiokai & 1 & 0 & 1 & 1 & 0 & 0 & 2 & 1 & 1 & 1 & 1 & 0 & 1 & 2 & 1 & 1 & 1 & 0 & 1 & 1 & 1 & 0 & 0 & 0 & 1 & 0 & 1 & 0 & 1 \\
\hline C. xanthogaster & 1 & 0 & 0 & 0 & 1 & 1 & 1 & 1 & 1 & 1 & 0 & 1 & 1 & 1 & 1 & 1 & 1 & 1 & 1 & 1 & 1 & 0 & 0 & 0 & 1 & 1 & 0 & 0 & 1 \\
\hline C. nigricauda & 1 & 0 & 0 & 0 & 1 & 1 & 1 & 1 & 1 & 1 & 0 & 1 & 1 & 1 & 1 & 1 & 1 & 1 & 1 & 1 & 1 & 0 & 0 & 0 & 1 & 1 & 0 & 0 & \\
\hline
\end{tabular}

$a-0$ or $1 ; b-1$ or 2 . 

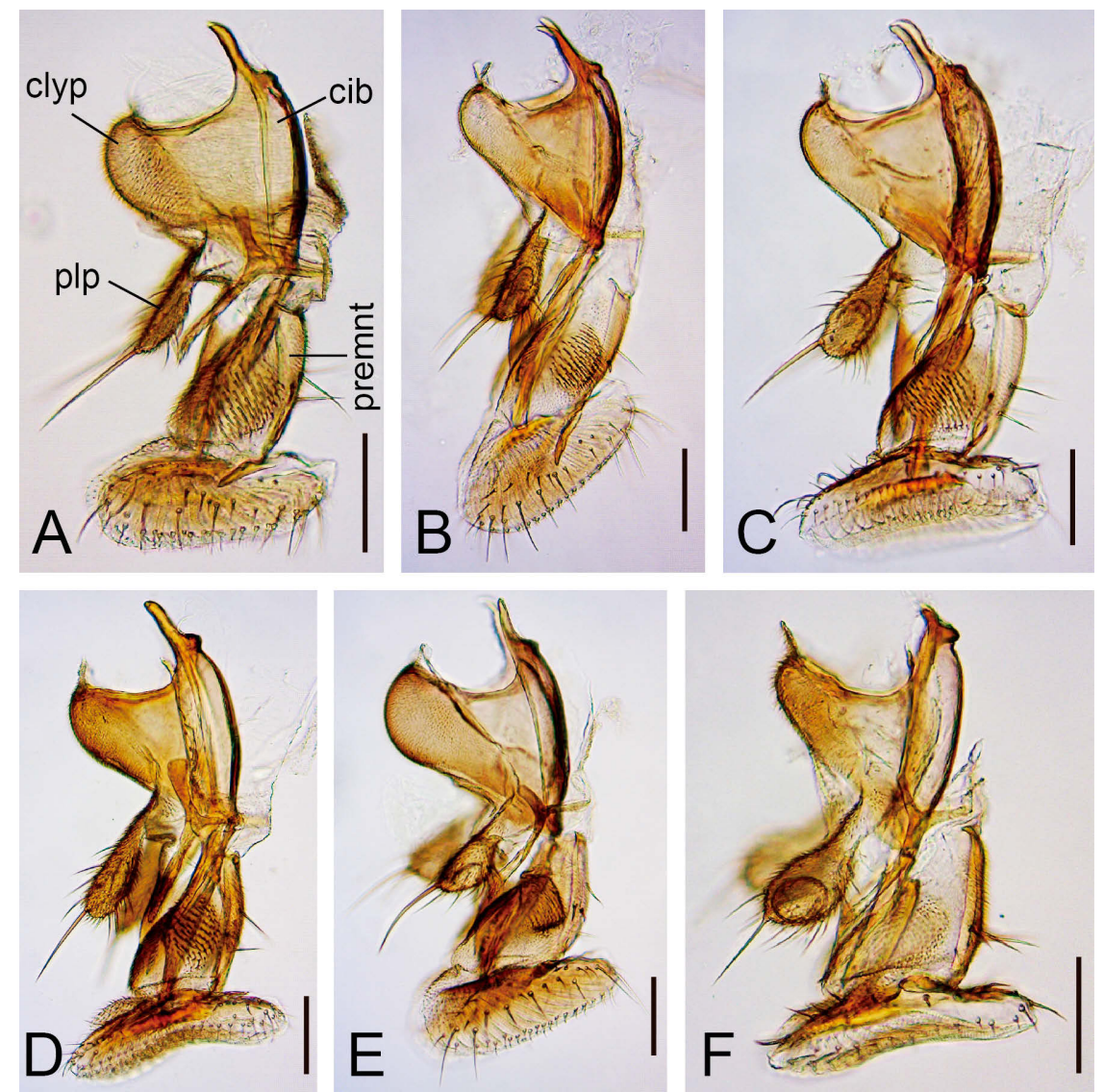

Fig. 5. Mouthparts (lateral view) of the Colocasiomyia toshiokai species group. A - C. toshiokai; B - C. xanthogaster; C - C. nigricauda; D - C. erythrocephala; E - C. heterodonta; F - C. rostrata sp. $n$. The photographed specimens are the same as those in Fig. 3 . Abbreviations: cib - cibarium, clyp - clypeus, plp - palpus, premnt - prementum. Scale bars: $0.1 \mathrm{~mm}$.

$\&$ Gao, sp. n., OTU2 $=$ C. nigricauda, OTU3 $=$ C. xanthogaster (but see Remarks for this species), and OTU4-6 $=$ C. heterodonta.

\section{Cladistic analysis}

\section{Characters}

As a result of the morphological study, a total of 29 characters were included in the cladistic analysis (Table 1). The polarity of each character was determined using the outgroup comparison method (Watrous \& Wheeler, 1981): all character states of $C$. sp. 1 aff. bogneri were coded as 0 (Table 1).

1. Antennal first flagellomere: (0) only slightly longer than pedicel (Fig. 3F); (1) 1.5 or more times as long as pedicel (Fig. 3A-E).

2. Small pouch on inner surface of first flagellomere: $(0)$ absent (Fig. 3A-C, F); (1) present (Fig. 3D, E).

3. Longest branch of arista: (0) longer than upper, prominent seta on pedicel (Fig. 3B, C); (1) as long as (Fig. 3A, D, E) or shorter than (Fig. 3F) upper, prominent seta on pedicel.

4. Distance between antennal sockets: $(0)$ greater than half of the diameter of the socket (Fig. 4B, C, E); (1) narrower than half the diameter of the socket (Fig. 4A, D, F).

5. Facial carina, width: (0) distinctly narrower than first flagellomere (Fig. 4A, F); (1) as wide as (Fig. 4E) or only slightly narrower than (Fig. 4B-D) first flagellomere.
6. Facial carina, length: (0) shorter than pedicel and first flagellomere combined (Fig. 4A, D-F); (1) as long as pedicel and first flagellomere combined (Fig. 4B, C).

7. Medial portion of clypeus: (0) thinner than distal portion of palpus (Fig. 5F); (1) as thick as distal portion of palpus (Fig. 5B, C); (2) thicker than distal portion of palpus (Fig. 5A, D, E).

8. Projections on anterolateral corners of cibarium: (0) shorter than half the width of cibarial anterior margin (Fig. 6F); (1) longer than width of its anterior margin (Fig. 6AE).

9. Rows of medial sensilla on cibarium: (0) wider than or (1) as wide as sensilla campaniformia (Fig. 6).

10. Supralateral pair of setae outside prementum plate: (0) present (Fig. 7E, F); (1) absent (Fig. 7A-D).

11. Acrostichal setulae, number of rows: (0) 2; (1) 4.

12. Additional pair of dorsocentral setae: (0) absent; (1) present.

13. Prominent seta(e) on postpronotal lobe: (0) 2 ; (1) 3 ; (2) 1 ; (3) not differentiated.

14. Costal setae, middle row from medial portion of 2 nd costal section to proximal portion of 3rd section: (0) apically blunt, thick, peg-like setae interspersed with thin, trichoid setae; (1) all apically blunt, thick, peg-like; (2) all thin, trichoid.

15. Pegs on foreleg tarsomere II: (0) 1 long and many small, tooth-like spines (Fig. 8B, C); (1) 3 long, stout spines (Fig. 8A). 

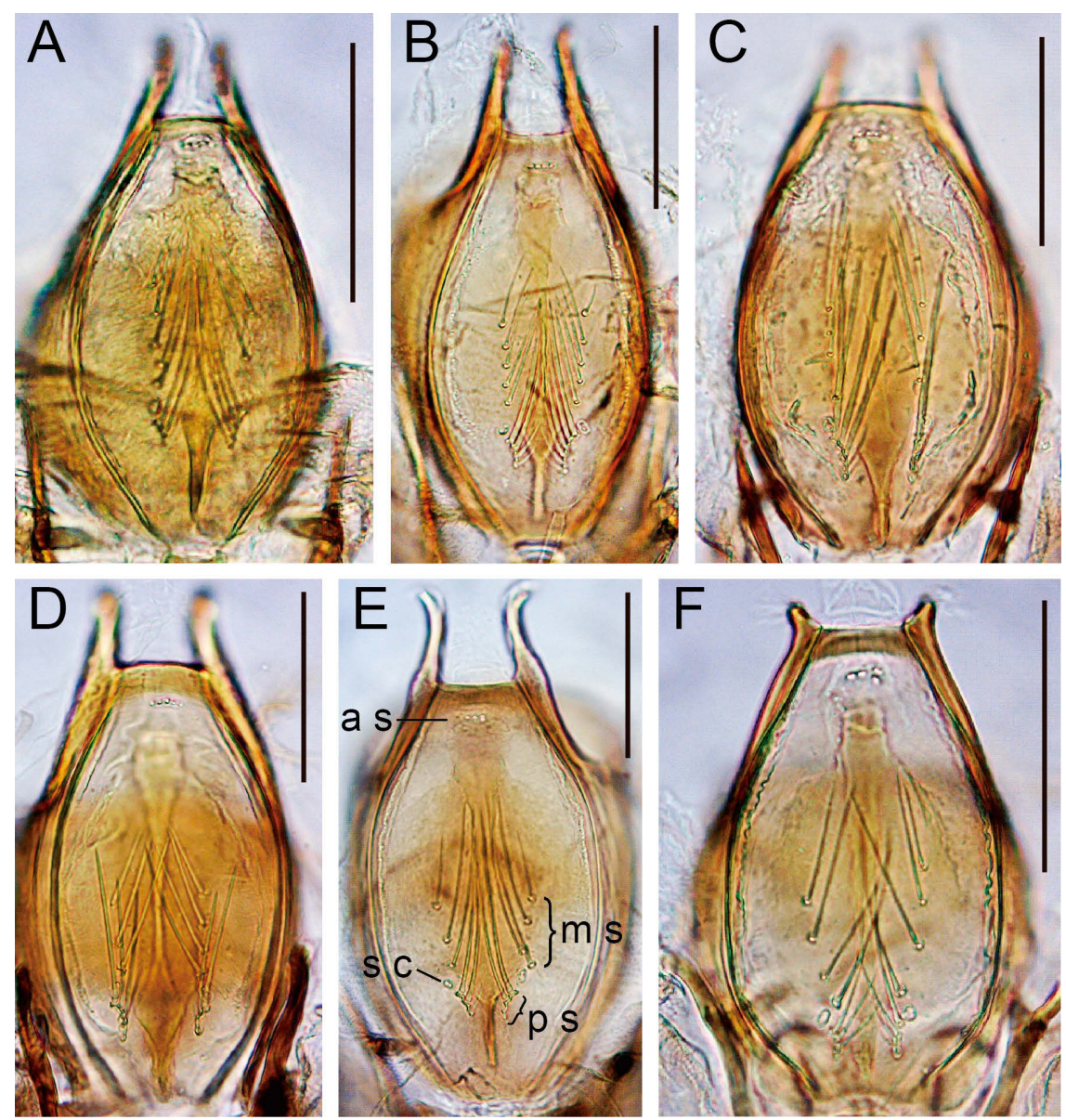

Fig. 6. Cibarium (posterior view) of the Colocasiomyia toshiokai species group. A - C. toshiokai; B - C. xanthogaster, C - C. nigricauda; D - C. erythrocephala; E - C. heterodonta; F - C. rostrata sp. n. The photographed specimens are the same as those in Fig. 3. Abbreviations: a s - anterior sensilla, $\mathrm{m} \mathrm{s}$ - medial sensilla, p s - posterior sensilla, s c - sensilla campaniformia. Scale bars: $0.1 \mathrm{~mm}$.

16. Long spine(s) on foreleg tarsomere II: (0) not sulcate (Fig. 8B); (1) sulcate (Fig. 8A, C).

17. Surstylus: (0) absent; (1) as narrow as ventral elongation of cercus (Fig. 2A-C in Sultana et al., 2002); (2) broader than ventral elongation of cercus (Fig. 10A; Fig. S3A; Fig. 2D, E in Sultana et al., 2002).

18. Thick, upright, claw-like prensisetae on apical margin of surstylus (nested to ch. 17-1, 2): (0) absent (Fig. 10A; Fig. S3A; Fig. 2A in Sultana et al., 2002); (1) present (Fig. 2B-E in Sultana et al., 2002).

19. Fusion of cercus to epandrium: (0) fused; (1) separated (Fig. 10A; Fig. S3A; Fig. 2 in Sultana et al., 2002).

20. Parameres: (0) absent; (1) basally fused to hypandrium (Fig. 10B, C; Fig. S3B, C; Figs 3, 4A, B in Sultana et al., 2002); (2) basally articulated with hypandrium (Fig. S2F, L, Q; Fig. 4C, D in Sultana et al., 2002).

21. Membranous distiphallus of aedeagus: (0) absent or very short (Fig. S2F, L, Q; Fig. S3B; Fig. 4A in Sultana et al., 2002); (1) long, tube-like (Fig. 3A, C, E in Sultana et al., 2002).

22. Aedeagus, length (aedL): (0) aedL $\geq$ apodeme (Fig. 3A, C, E in Sultana et al., 2002); (1) $1 / 2$ apodeme $\leq$ aedL $<$ apodeme (Fig. 10B; Figs S3B, S2Q; Fig. 4A in Sultana et al., 2002); (2) aedL < 1/2 apodeme (Fig. S2F, L).
23. Apex of aedeagus: (0) narrow, pointed (Fig. 3A, C, E in Sultana et al., 2002); (1) broad, round (Fig. 10B; Figs S3B, S2F, L, Q; Fig. 4A in Sultana et al., 2002).

24. Aedeagus, beak-like projection between basal processes: (0) absent (Fig. 3A, C, E in Sultana et al., 2002); (1) present (Fig. 10B; Figs S3B, S2F, L, Q; Fig. 4A in Sultana et al., 2002).

25. Female sternite VII, caudomedial margin: (0) not deeply notched; (1) deeply notched.

26. Epiproct, pubescence: (0) present (Fig. S3D); (1) absent.

27. Hypoproct, pubescence: (0) absent; (1) present (Fig. $\mathrm{S} 3 \mathrm{E})$.

28. Apical portion of oviscapt: (0) more or less elongated, forming a projection (Fig. 10D; Fig. S3D, E; Fig. 5A-D in Sultana et al., 2002); (1) roundish, without distinct projection (Fig. 5E in Sultana et al., 2002); (2) truncate.

29. Long, upright seta on dorsosubapical corner of oviscapt: (0) absent (Fig. 5E in Sultana et al., 2002); (1) present (Fig. 10D; Fig. S3D; Fig. 5A-D in Sultana et al., 2002).

\section{Cladogram}

The parsimony analysis of the morphological data matrix (Table 1) resulted in a single most parsimonious clado- 


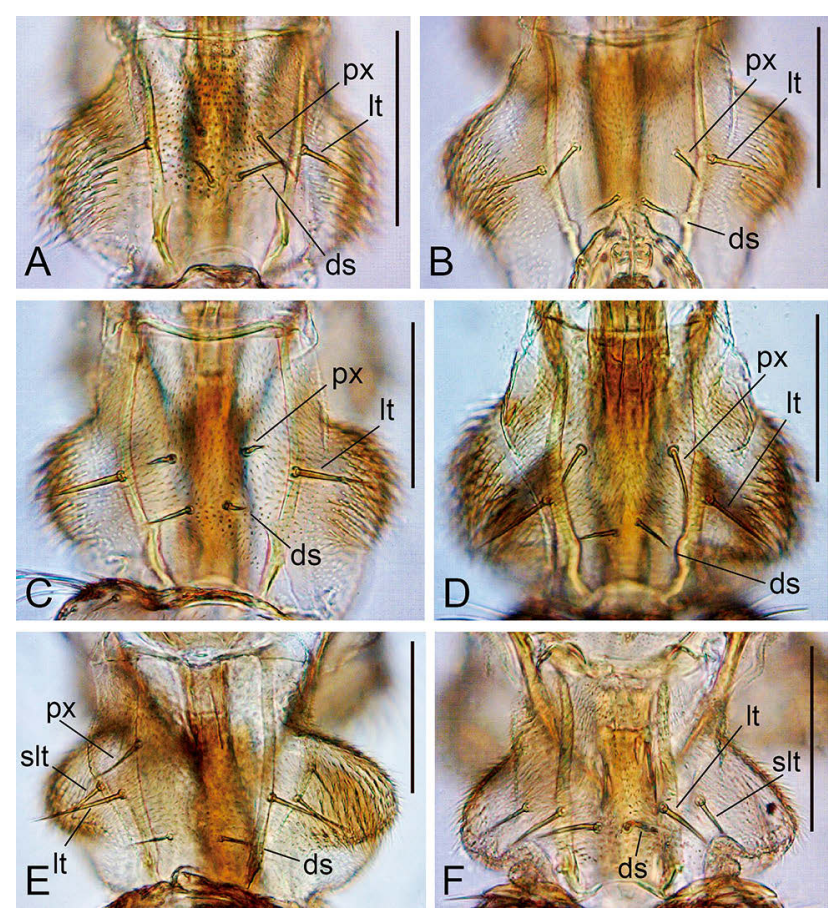

Fig. 7. Prementum (posterior view) of the Colocasiomyia toshiokai species group, with indication of the homology of setae. $A-C$ toshiokai; B - C. xanthogaster; C - C. nigricauda; D - C. erythrocephala; E - C. heterodonta; F - C. rostrata sp. $\mathrm{n}$. The photographed specimens are the same as those in Fig. 3. Abbreviations: ds - distal, It - lateral, px - proximal, slt - supralateral pair of setae. Scale bars: $0.1 \mathrm{~mm}$.

gram with a length of 59 steps and the following statistics: CI (consistency index) $=0.610$, RI (characters retention index $)=0.681$ and RC (rescaled consistency index) = 0.415 . The tree was rooted by outgroup rooting (Fig. 9). Apomorphies are indicated on each branch based on the ACCTRAN estimations. The results of character optimization were inconsistent for some transformation series between ACCTRAN and DELTRAN (not shown). Synapomorphies not identified by both ACCTRAN and DELTRAN are excluded from the following description.

The resulting cladogram (Fig. 9) was compatible with the COI tree (Fig. 2). The monophyly of the toshiokai group was supported with $\mathrm{BP}=73$. Although the tree topology within the toshiokai group was not so highly resolved in terms of BP values, some morphological characters suggested phylogenetic relationships for some species. Colocasiomyia rostrata sp. n. was placed as the most basal branch within the toshiokai group. This species lacks some synapomorphies of the sister clade comprised of all the other ingroup species: antennal first flagellomere at least 1.5 times as long as pedicel (ch. 1-1); medial portion of clypeus as thick as or thicker than distal portion of palpus (ch. 7-1, 2); and long spine(s) on foreleg tarsomere II sulcate (ch. 16-1). This species shares the plesiomorphic states for these characters with the outgroup species.

Of the remaining species, the sibling $C$. xanthogaster and $C$. nigricauda formed a compact clade $(\mathrm{BP}=99)$ supported by the following apomorphies: facial carina as long as pedicel and first flagellomere combined (ch. 6-1); and

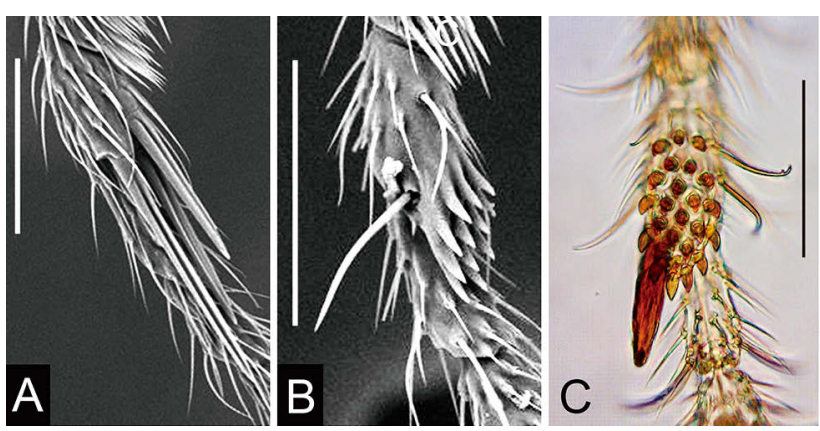

Fig. 8. Foreleg tarsomere II (A, B - inner-lateral view; $C$ - ventral view) of the Colocasiomyia toshiokai species group. A - C. xanthogaster (Dark II; 9 \#02803 from Tumokang, Dumoga Bone National Park, North Sulawesi, Indonesia); B - C. rostrata sp. n. (paratype ऽ \#02713 from Lembah Anai, West Sumatra, Indonesia); C - C. heterodonta ( $\delta$ from Bogor Botanical Garden, Bogor, West Java, Indonesia). Scale bars: $0.1 \mathrm{~mm}$.

medial portion of clypeus as thick as distal portion of palpus (ch. 7-1). However, the relationships of this clade to $C$. erythrocephala and C. toshiokai remain uncertain (but see Remarks for the latter two species).

\section{Taxonomic account}

\section{Genus Colocasiomyia de Meijere, 1914 Colocasiomyia toshiokai species group}

Colocasiomyia toshiokai species group, Sultana et al., 2002: 306; Sultana et al., 2006: 694 (revised).

One new and five known species are here described and redescribed, respectively, with reference to the previous taxonomic studies on this species group (Toda \& Okada, 1983; Yafuso \& Okada, 1990; Sultana et al., 2002, 2006).

Diagnosis (Sultana et al., 2002, 2006, with minor modifications). Palpus subapically with large cavity (Fig. 5; Fig. $1 B$ in Sultana et al., 2002). Prementum laterally with a pair of spherical bumps covered with numerous short setae (Figs 5, 7; Fig. 1C in Sultana et al., 2002). Surstylus basally broad, distally elongated, with only weak, trichoid setae, and dorsobasally fused to cercus (Figs 10A, S3A; Fig. 2 in Sultana et al., 2002). Cercus ventrally with conspicuous elongation curved posteriad (Figs 10A, S3A; Fig. 2 in Sultana et al., 2002). Aedeagus basally with a pair of strongly sc1erotized processes (Figs 10B, S2E, K, P, S3C; Figs 3, 4 in Sultana et al., 2002).

Characters shared by all the species. Eye with sparse interfacetal setulae (Fig. 4).

The characters described as shared among the known species in this species group by Sultana et al. (2002) are not referred to in the descriptions below if also present in the new species.

\section{Colocasiomyia toshiokai (Okada, 1983)}

(Figs 3-7A)

Drosophilella toshiokai Okada in Toda \& Okada, 1983: 173.

Colocasiomyia toshiokai: Okada, 1988: 36; Sultana et al., 2002: 307.

Diagnosis. Acrostichal setulae in 4 rows. Surstylus sinuated, as thin as, but longer than ventral elongation of cer- 


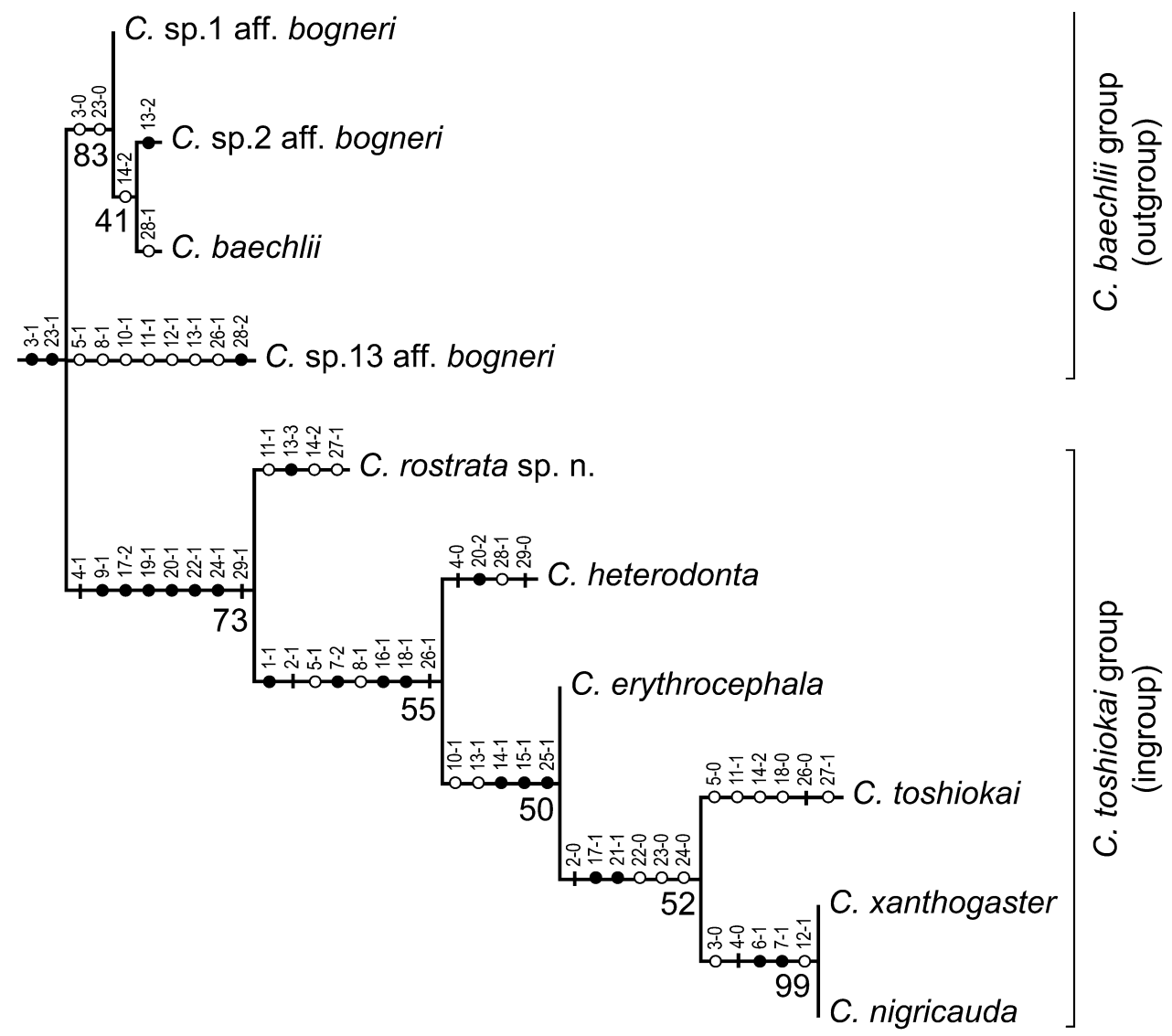

Fig. 9. The single most parsimonious cladogram resulting from a PAUP* $(4.0 \mathrm{~b} 10)$ parsimony analysis of the morphological character matrix (Table 1) for the Colocasiomyia toshiokai species group. Apomorphies inferred from ACCTRAN character optimization are indicated on each branch: solid circle - nonhomoplastic change; open circle - homoplastic (parallel and reversal) change; bar - change inconsistent with DELTRAN inference (not shown). The support values (bootstrap frequency \%) are indicated beside each branch.

cus, rounded at apex, with 4 minute, submedial to apical setulae (Fig. 2A in Sultana et al., 2002).

Redescription. Antennal first flagellomere approximately 1.5 times as long as pedicel, without small pouch on inner surface; longest branch of arista as long as upper, prominent seta on pedicel (Fig. 3A). Facial carina somewhat roundly demarcated below, much shorter than pedicel and first flagellomere combined (Fig. 4A). Clypeus medially much thicker than distal portion of palpus (Fig. 5A). Projections on anterolateral corners of cibarium longer than width of its anterior margin (Fig. 6A). Prementum with 3 (proximal, lateral and distal) pairs of setae, lacking supralateral pair of setae outside prementum plate (Fig. 7A). Foreleg tarsomere II with 3 long, stout, sulcate spines. Epiproct and hypoproct with pubescence. Female sternite VII deeply notched on caudomedial margin.

Type material examined. PHILIPPINES: $1 \hat{\jmath}, 1+$ (paratypes), Mindanao, Surigao, 17.vii.1981 (S. Toshioka) (NSMT).

Distribution. Philippines (Mindanao).

Remarks. This species was placed as the sister to the clade of $C$. xanthogaster and $C$. nigricauda in the most parsimonious cladogram (but $\mathrm{BP}=52$; Fig. 9), with the following synapomorphies: surstylus as narrow as ventral elongation of cercus (ch. 17-1); and aedeagus with long, tube-like, membranous distiphallus (ch. 21-1). On the other hand, this species also seems to be related to $C$. rostrata sp. n., sharing the following homoplastic apomorphies: acrostichal setulae in 4 rows (ch. 11-1); costal setae in middle row from medial portion of 2 nd costal section to proximal portion of $3 \mathrm{rd}$ section all thin, trichoid (ch. 14-2); and hypoproct pubescent (ch. 27-1).

Colocasiomyia xanthogaster Yafuso \& Okada, 1990 (Figs 3-7B, 8A, S1; Table S3)

Colocasiomyia xanthogaster Yafuso \& Okada, 1990: 138; Sultana et al., 2002: 308.

Colocasiomyia sp. aff. xanthogaster: Sultana et al., 2006: 694.

Diagnosis. Additional pair of dorsocentral setae present before transverse suture, approximately $2 / 3$ as long as anterior dorsocentral setae. Surstylus strongly curved downward, rounded at apex (Fig. 2B in Sultana et al., 2002). Aedeagus apically narrow and clawed (Fig. S1M-O).

Redescription. Antennal first flagellomere approximately 1.5 times as long as pedicel, without small pouch on inner surface; longest branch of arista longer than upper, prominent seta on pedicel (Fig. 3B). Clypeus medially nearly as thick as distal portion of palpus (Fig. 5B). Projections on anterolateral corners of cibarium longer than width of its anterior margin; medial and posterior cibarial sensilla 3-6 and 4-6 per side, respectively (Fig. 6B). Prementum with 3 (proximal, lateral and distal) pairs of setae, lacking supralateral pair of setae outside prementum plate (Fig. 7B). 
Foreleg tarsomere II with 3 long, stout, sulcate spines (Fig. 8A). Aedeagus without beak-like projection between basal processes (Fig. S1M-O; Fig. 3D, E in Sultana et al., 2002). Epiproct and hypoproct not pubescent. Female sternite VII deeply notched on caudomedial margin.

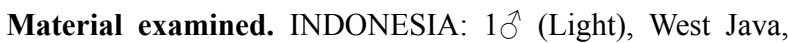
Bogor, Bogor Botanical Garden, 6³6'9.9"S, 106 $47^{\prime} 47.8^{\prime \prime} \mathrm{E}, 273$ m a.s.1., 22.i.2004, ex H. pendula (M.J. Toda) (SEHU); $1 \delta^{\lambda}, 1$ 우 (Light), ditto, except 27.i.2004 (MZB); $2 \widehat{\jmath}$ (1 Light, 1 Dark I), West Sumatra, Padang Panjang, Batangang, 5.i.2004, ex Homalomena sp. (M.J. Toda) (SEHU); $1 \widehat{O}^{\hat{\gamma}}$ (Light), West Sumatra, Sungai Penuh - Tapan, 700 m a.s.1., 7.xii.2004, ex Homalomena sp.PT (Fig. S5) (K.T. Takano) (MZB); $1 \hat{\jmath}^{\wedge}$ (Dark I), West Sumatra, Lembah Anai, $0^{\circ} 28^{\prime} 55.3^{\prime \prime} \mathrm{S}, 100^{\circ} 20^{\prime} 17.7^{\prime \prime} \mathrm{E}, 250 \mathrm{~m}$ a.s.l., 19.xii.2003, ex Homalomena sp. (M.J. Toda) (SEHU); $1 \hat{\jmath}, 2$ 우 (Dark I), West Sumatra, Lembah Anai, 9.xii.2004, ex Homalome-

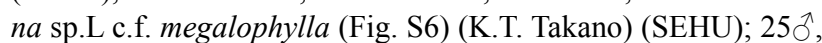
23 ㅇ (\#02778-2825, Dark II), North Sulawesi, Dumoga Bone National Park, Tumokang, 0³6'6.33"N, 12352'28.61"E, $478 \mathrm{~m}$ a.s.1., 21.xii.2003, ex Homalomena sp. aff. alba (Fig. S7) (K.T.

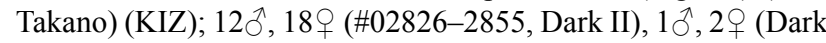
II), North Sulawesi, Toraut, $0^{\circ} 32^{\prime} 49.3^{\prime \prime} \mathrm{N}, 123^{\circ} 49^{\prime} 7.67^{\prime \prime} \mathrm{E}, 587 \mathrm{~m}$ a.s.1., 19.xii.2003, ex Homalomena sp.T (Fig. S8) (K.T. Takano) (SEHU); 8ภ, 19 ( \#02856-2882, Dark II), North Sulawesi, Desa Tinoor, 22.xii.2003, ex Homalomena sp. (K.T. Takano) (SEHU). MALAYSIA: 19 (Light), Sarawak, Kuching, Siburan, Kampung Giam, Air Terjun, $1^{\circ} 19^{\prime} 11.2^{\prime \prime N}, 110^{\circ} 16^{\prime} 11.4^{\prime \prime} \mathrm{E}, 37 \mathrm{~m}$ a.s.1., xii.2009, ex Homalomena giamensis L.S. Tung, S.Y. Wong \& P.C. Boyce (S.Y. Wong) (SEHU).

Distribution (* new record). Indonesia (Java, West Kalimantan, Sumatra*, Sulawesi*), Malaysia* (Sarawak).

Remarks. Some local populations vary morphologically. The light form (including the holotype) has light (pale yellow in female and pale brown in male) abdominal tergites, as reflected in the specific name xanthogaster, and its foreleg tibia lacks dark patch on apical portion of inner surface (Fig. S1A). The dark form, which is regarded as a different morpho-species, "sp. aff. xanthogaster", by Sultana et al. (2006), has nearly entirely dark grey to black abdominal tergites and a dark patch on apical portion of inner surface of the foreleg tibia (Fig. S1B, C). Specimens of the light form have been collected in West Java, West Sumatra, West Kalimantan and Sarawak, and those of the dark form in West Sumatra and North Sulawesi. In the present study the detailed morphological comparison revealed that some characters other than body colour are different between Sumatran and Sulawesian populations of the dark form. Thus, three morphological forms, Light, Dark I (Sumatra) and Dark II (Sulawesi), are recognised within $C$. xanthogaster, and Light and Dark I forms co-occur in West Sumatra (see Table S3 and Fig. S1 for details). Although intraspecific pigmentation polymorphisms have been repeatedly observed in drosophilid species (e.g., Gibert et al., 1999; Wittkopp et al., 2003), the observed differences in structures and setation of some organs suggest a possibility that the three forms are good sibling species. However, the COI barcoding detected no distinct genetic differentiation among them. Therefore, we refrain from treating the two Dark forms as good species until more crucial evidence is obtained.

\section{Colocasiomyia nigricauda Sultana \& Toda, 2002}

(Figs 3-7C)

Colocasiomyia nigricauda Sultana \& Toda in Sultana et al., 2002: 309.

Diagnosis. Additional pair of dorsocentral setae present before transverse suture, approximately $3 / 4$ as long as anterior dorsocentral setae. Surstylus gently curved downwards, apically triangular (Fig. 2C in Sultana et al., 2002). Aedeagus shaped like thick claw apically (Fig. 3E in Sultana et al., 2002).

Redescription. Antennal first flagellomere approximately 1.5 times as long as pedicel, without small pouch on inner surface; longest branch of arista longer than upper, prominent seta on pedicel (Fig. 3C). Facial carina as long as pedicel and first flagellomere combined, somewhat truncately demarcated below (Fig. 4C). Clypeus medially nearly as thick as distal portion of palpus (Fig. 5C). Projections on anterolateral corners of cibarium longer than width of its anterior margin; medial, cibarial sensilla 3-8 per side (Fig. 6C). Prementum with 3 (proximal, lateral and distal) pairs of setae, lacking supralateral pair of setae outside prementum plate (Fig. 7C). Foreleg tarsomere II with 3 long, stout, sulcate spines (Fig. 1E in Sultana et al., 2002). Aedeagus without beak-like projection between basal processes (Fig. 3E in Sultana et al., 2002). Epiproct and hypoproct not pubescent. Female sternite VII deeply notched on caudomedial margin.

Material examined. MALAYSIA: $1 \hat{\delta}$, Sabah, Crocker Range, Inobong, $5^{\circ} 51^{\prime} 22.2^{\prime \prime} \mathrm{N}, 116^{\circ} 8^{\prime} 13.4^{\prime \prime} \mathrm{E}, 500 \mathrm{~m}$ a.s.1., 7. viii. 2003 , ex Homalomena sp.P belonging to the Hanneae complex (Fig.

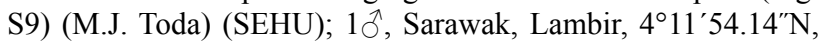
$114^{\circ} 2^{\prime} 34.34^{\prime \prime} \mathrm{E}, 68 \mathrm{~m}$ a.s.1., 17.xi.2004, ex H. lambirensis (Fig. S10) (K.T. Takano) (FRCK). INDONESIA: 1ठ, West Sumatra, Sungai Penuh - Tapan, 7.xii.2004, ex Homalomena sp.PT (K.T. Takano) (MZB); 1ð̄, West Java, Mt. Halimun, Cikaniki, $6^{\circ} 44^{\prime} 42.5^{\prime \prime} \mathrm{S}, 106^{\circ} 32^{\prime} 14.5^{\prime \prime} \mathrm{E}, 1051 \mathrm{~m}$ a.s.1., 7.xi.2009, ex H. megalophylla (M.J. Toda) (SEHU).

Distribution. Malaysia (Sabah, Sarawak), Indonesia* (Sumatra, Java).

Remarks. The specimens collected from Indonesia were identified as being conspecific with those from the type locality, i.e., Poring, Sabah, Malaysia, based on morphology and DNA barcoding (Fig. 2).

\section{Colocasiomyia erythrocephala Sultana \& Yafuso, 2002}

(Figs 3-7D)

Colocasiomyia erythrocephala Sultana \& Yafuso in Sultana et al., 2002: 311.

Diagnosis. Three stout spines on foreleg tarsomere II slightly longer than tarsomeres III and IV combined. Surstylus straight, as long as but slightly broader than ventral elongation of cercus, rounded at apex (Fig. 2D in Sultana et al., 2002). Aedeagus broad, apically thick and rounded, with beak-like projection between a pair of strongly sclerotized, basal processes (Fig. 4A in Sultana et al., 2002). 
Redescription. Supracervical setae 3-5 per side. Antennal first flagellomere approximately twice as long as pedicel, with small pouch on inner surface; longest branch of arista as long as upper, prominent seta on pedicel (Fig. 3D). Facial carina roundly demarcated below, shorter than pedicel and first flagellomere combined (Fig. 4D). Clypeus medially thicker than distal portion of palpus (Fig. 5D). Projections on anterolateral corners of cibarium longer than width of its anterior margin; posterior, cibarial sensilla 3-5 per side (Fig. 6D). Prementum with 3 (proximal, lateral and distal) pairs of setae, lacking supralateral pair of setae outside prementum plate (Fig. 7D). Foreleg tarsomere II with 3 long, stout, sulcate spines. Epiproct and hypoproct not pubescent. Female sternite VII deeply notched on caudomedial margin.

Type material examined. VIETNAM: $3 \hat{\partial}, 1 \propto$ (paratypes), Cuc Phuong, 19.vi.2000, ex Homalomena vietnamensis Bogner \& V.D. Nguyen (Fig. S11) (M. Yafuso) (SEHU).

Distribution. Vietnam.

Remarks. This species seems to be intermediate in morphology between $C$. heterodonta and the clade of $C$. xanthogaster and $C$. nigricauda, sharing two apomorphies (ch. 2-1, antennal first flagellomere with small pouch on inner surface; and ch. 17-2, surstylus broader than ventral elongation of cercus) with the former, but also three apomorphies (ch. 14-1, costal setae in middle row from medial portion of 2 nd costal section to proximal portion of $3 \mathrm{rd}$ section all apically blunt, thick, peg-like; ch. 15-1, fore tarsomere II with 3 long, stout spines; and ch. 25-1, female sternite VII deeply notched on caudomedial margin) with the latter.

\section{Colocasiomyia heterodonta Yafuso \& Okada, 1990}

(Figs 3-7E, 8C, S2; Table S4)

Colocasiomyia heterodonta Yafuso \& Okada, 1990: 140; Sultana et al., 2002: 313.

Colocasiomyia sp. aff. heterodonta: Sultana et al., 2006: 694; Hoe et al., 2016: 569.

Colocasiomyia sp. 3 aff. heterodonta: Sultana et al., 2006: 694.

Diagnosis. Foreleg tarsomere II with 1 long, stout, sulcate spine and many small, tooth-like spines arranged in irregular rows (Figs 8C, S2C, D, I, J, O). Parameres basally articulated with hypandrium (Fig. S2F, L, Q; Fig. 4C, D in Sultana et al., 2002). Oviscapt apically tapering but without distinct projection (Fig. 5E in Sultana et al., 2002).

Redescription. Antennal first flagellomere with small pouch on proximal portion of inner surface in addition to large, hollow organ on inner margin and small, invaginated organ; longest branch of arista as long as upper, prominent seta on pedicel (Fig. 3E). Clypeus medially much thicker than distal portion of palpus (Fig. 5E). Projections on anterolateral corners of cibarium longer than width of its anterior margin (Fig. 6E). Prementum with 4 (proximal, lateral, supralateral and distal) pairs of setae (Fig. 7E). Postpronotal lobe with 2 prominent setae and 2-3 short setulae; upper prominent seta longer. Scutum and scutellum glossy, dark brown. Anterior dorsocentral setae slightly behind transverse suture. Additional pair of dorso- central setae absent. Acrostichal setulae in 2 rows. Basal and apical scutellar setae convergent; apicals not cruciate. Wing nearly hyaline, apically more or less clouded. Costa with apically blunt, heavy, peg-like setae interspersed with weak, trichoid setae in middle row. Epandrium pubescent except for anterior margin and ventral portion (Fig. 2E in Sultana et al., 2002). Surstylus broader than ventral elongation of cercus (Fig. 2E in Sultana et al., 2002). Paramere basally articulated with aedeagal guide (Fig. S2F, L, Q; Fig. 4C in Sultana et al., 2002). Aedeagus apically broad and round, with strongly sclerotized, apically pointed (in lateral view), beak-like projection between basal processes; membranous distiphallus very short (Fig. S2F, L, Q). Female sternite VII not deeply notched on caudomedial margin. Epiproct slightly pubescent; hypoproct not pubescent. Oviscapt without long, upright seta on dorsosubapical corner (Fig. 5E in Sultana et al., 2002).

Material examined. Form I - INDONESIA: $2 \hat{\delta}$, West Java, Bogor, Bogor Botanical Garden, 2.i.2005, ex H. pendula (M.J. Toda) (SEHU); 4^, 5, West Java, Bogor, Bogor Botanical Garden, 22.i.2004, ex Homalomena sp. (M.J. Toda) (MZB); 2ð, 6오, West Java, Bogor, Bogor Botanical Garden, 22.xii.2003, ex Aglaonema simplex (Blume) Blume (M.J. Toda) (SEHU); $10 \AA$, 18 , West Java, Mt. Gede-Pangarango National Park, Salabintana, 649'54.3"S, 106 $58^{\prime} 17.2^{\prime \prime} \mathrm{E}, 1100 \mathrm{~m}$ a.s.1., 1.i.2004, ex Homalomena sp. (M.J. Toda) (MZB); 26§ , 21, West Java, Mt. Halimun, Cikaniki, 18.i.2004, ex H. megalophylla (M.J. Toda) (SEHU); $1 \delta^{\lambda}$, West Java, Kelapa Nunggal, 6 $6^{\circ} 50^{\prime} 1.2^{\prime \prime} \mathrm{S}$, $106^{\circ} 38^{\prime} 59.5^{\prime \prime} \mathrm{E}, 567 \mathrm{~m}$ a.s.1., 31.x.2009, ex H. megalophylla (M.J. Toda) (SEHU); $2 \hat{\jmath}, 1$, , West Sumatra, Sungai Penuh - Tapan, 7.xii.2004, ex Homalomena sp.PT (K.T. Takano) (MZB); 7ð̋, 8ㅇ, West Sumatra, Padang Panjang, Batangang, 5.i.2004, ex Homalomena sp. (M.J. Toda) (SEHU). Form II - MALAYSIA: 2ิ̂, 1 ㅇ (\#02755-2757), Sarawak, Betong, Roban, Sebankoi, Taman Rekreasi Sebankoi, 01 ${ }^{\circ} 57^{\prime} 27.4^{\prime \prime} \mathrm{N}, 111^{\circ} 26^{\prime} 04.6^{\prime \prime} \mathrm{E}, 154 \mathrm{~m}$ a.s.1., 5.xii.2005, ex Homalomena ibanorum S.Y. Wong \& P.C. Boyce (P.C. Boyce, Jeland ak Kisai, Jepom ak Tisai, Mael ak Late and Wong Sin Yeng) (UNIMAS); $1 \hat{\jmath}$ (\#02754), Sarawak, Kuching, Siburan, Kampung Giam, Sugun Jawan, $1^{\circ} 19^{\prime} 16.1^{\prime \prime} \mathrm{N}$, $110^{\circ} 16^{\prime} 16.7^{\prime \prime} \mathrm{E}, 50 \mathrm{~m}$ a.s.1., 31.xii.2012, ex Homalomena cf. borneensis (P.C. Boyce and Wong Sin Yeng) (UNIMAS); 14 $\hat{\circ}, 6$ 우 (\#02758-2777), Sarawak, Kuching, Siburan, Kampung Giam, Air Terjun Giam, 1¹9'11.2”N, 110¹6'11.4"E, 37 m a.s.1., 12.ii.2011, ex H. giamensis (P.C. Boyce, Jeland ak Kisai and Wong Sin Yeng)

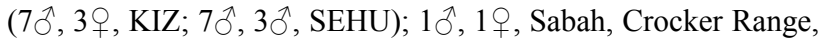
Inobong, 7.viii.2003, ex Homalomena sp.P (M.J. Toda) (BORN); 1 우 [identified as C. heterodonta by Sultana et al. (2002)], Sabah, Crocker Range, Ulu Senagang, 500 m a.s.l., 18.x.1999, ex Homalomena sp.P (M.J. Toda) (SEHU); $3 \partial^{\lambda}, 1$, , Sabah, Mt. Kinabalu, Poring, $6^{\circ} 2^{\prime} 55.5^{\prime \prime} \mathrm{N} 116^{\circ} 42^{\prime} 8.2^{\prime \prime} \mathrm{E}, 500 \mathrm{~m}$ a.s.l., 11.iii.2000, ex Homalomena sp.P (M.J. Toda) (1へ, 1q, KPSP; $2 \hat{\jmath}$, SEHU). Form III - INDONESIA: 1 $\jmath^{\lambda}, 29$ (\#02751-2753), Sumatra, Jambi, Mt. Kerinci, $1^{\circ} 45^{\prime} 5.9^{\prime \prime} \mathrm{S}, 101^{\circ} 15^{\prime} 34.6^{\prime \prime} \mathrm{E}, 1800-2000 \mathrm{~m}$ a.s.1., 7.x.2004, ex Homalomena sp.K (Fig. S12) (M.J. Toda) (1 $\hat{\sigma}^{\text {, }}$ 1 ㅇ, MZB; 1 ,, SEHU).

Distribution. Malaysia (Sabah, Sarawak*), Indonesia (Java, Sumatra).

Remarks. Morphological differences among the Forms I-III of this species are summarized in Table S4 and Fig. S2. Form III is specifically different from the other two forms in the structure of the male phallic organs, with a longer aedeagus, longer and more strongly curved basome- 
dial, beak-like projection on aedeagus, and an apicolaterally extended paramere (Fig. S2P, Q). On the other hand, Forms I and II are almost identical in the detailed structure of male genitalia (Fig. S2E, F, K, L), although there are subtle differences in a few of their external characters (Table S4).

\section{Colocasiomyia rostrata Shi \& Gao, sp. n.}

(Figs 3-7F, 8B, 10, S3)

ZooBank taxon LSID:

EA25FA47-4241-4642-A00A-801A8FE5FF24

Colocasiomyia sp. 2 aff. heterodonta: Sultana et al., 2006: 694.

Diagnosis. Antennal aristal branches minute; first flagellomere only slightly longer than pedicel, without small pouch on inner surface (Fig. 3F). Projections on anterolateral corners of cibarium shorter than half the width of cibarial, anterior margin (Fig. 6F). Lateral bumps on prementum covered with short, thin setae (Figs 5F, 7F). Postpronotal lobe with approximately 10 setae; longest one not prominent, as thin as others. Long spine on foreleg tarsomere II thin, simple, not sulcate (Fig. 8B). Aedeagal basal beak-like projection longer than aedeagus proper, apically rounded (Fig. 10B). Oviscapt apically bilobed: dorsal lobe with 1 long, upright seta on dorsosubapical corner, 1 peg-like, upward-curved ovisensillum at apex, 1 short seta dorsosubapically near base of apical, peg-like ovisensillum and 1 or 2 seta(e) on ventrosubapical margin; ventral lobe with 7-8 short setulae along caudoventral margin (Figs 10D, S3D, E).

Description. Male. Head: Eye brownish red. Supracervical setae $2-4$, and postoculars $18-19$ per side. Frontal vittae mat, greyish yellow. Distance between antennal sockets narrower than half of socket width (Fig. 4F); pedicel greyish yellow, dorsally with a few stout setae approximately half as long as prominent setae; arista with 3-4 dorsal and 2-3 ventral branches (Fig. 3F). Facial carina less demarcated below, slightly shorter than pedicel and first flagellomere combined, narrower than first flagellomere (Fig. 4F). Gena greyish brown. Palpus greyish yellow, much dilated distally (Fig. 5F). Clypeus medially thinner than distal portion of palpus (Fig. 5F). Cibarial, medial and posterior sensilla 4 and $2-4$, respectively, per side; posterior sensilla much shorter than medial ones; 4 anterior sensilla arranged in somewhat irregular, transverse row (Fig. 6F). Prementum with 3 (lateral, supralateral and distal) pairs of setae nearly arranged in a transverse row (Fig. 7F). Labellum with 11-12 pseudotracheae per side.

Thorax: entirely dark brown. Acrostichal setulae in 4 rows; setulae in inner rows approximately half as long as anterior dorsocentral setae. Additional pair of dorsocentral setae absent. Apical, scutellar setae nearly parallel.

Wing: hyaline, apically not clouded. Veins pale brown; $\mathrm{R}_{4+5}$ and $\mathrm{M}_{1}$ slightly converging apically. Costal setae in middle row all weak, trichoid. Halter dark brown.

Legs: Foreleg tarsomere II with 1 long and 9-14 short, stout spines (Fig. 8B).

Abdomen: Tergites blackish brown. Sternites greyish brown.
Terminalia (Figs 10A-C, S3A-C): Epandrium with 8-9 setae on dorsal to lateral portion and approximately 5 near base of surstylus. Surstylus blade-shaped, apically somewhat triangular, with 3 minute setae on apical portion. Cercus with approximately 37 setae; ventral elongation with approximately 2 minute tooth-like setulae on dorsosubapical margin. Paramere basally fused to hypandrium, slightly shorter than aedeagus, distally curved inwards, apically rounded, with 4 minute sensilla. Aedeagus approximately half as long as apodeme, apically broad and round, with short but broad, aedeagal guide; membranous distiphallus very short.

Measurements (holotype/range in $5 \hat{\jmath}$ paratypes, in $\mathrm{mm}): \mathrm{BL}=2.00 / 1.90-2.00, \mathrm{ThL}=0.87 / 0.80-0.87, \mathrm{WL}=$ $1.77 / 1.60-1.87, \mathrm{WW}=0.77 / 0.77-0.93$.

Indices (holotype/range in 50 paratypes, in ratio): $\mathrm{FW} /$ HW (frontal width/head width) $=0.53 / 0.56-0.63, \mathrm{ch} / \mathrm{o}$ (maximum width of gena/maximum diameter of eye) $=0.39 / 0.28-0.44$, prorb (proclinate orbital seta length/ posterior reclinate orbital seta length $)=0.83 /(\mathrm{n} / \mathrm{a})$, rcorb (anterior reclinate orbital seta length /posterior reclinate orbital seta length) $=0.25 / 0.42-0.56$, vb (subvibrissal seta length /vibrissa length) $=0.21 / 0.23-0.25$, dcl (anterior dorsocentral seta length/posterior dorsocentral seta length $)=(\mathrm{n} / \mathrm{a}) / 0.56-0.74$, presctl (prescutellar seta length /posterior dorsocentral seta length $)=0.62 / 0.63-0.78$, sctl (basal scutellar seta length /apical scutellar seta length) $=$ $0.49 / 0.50-0.65$, sterno (anterior katepisternal seta length/ posterior katepisternal seta length) $=0.67 / 0.47-0.60$, orbito (distance between proclinate and posterior reclinate orbital setae/distance between inner vertical and posterior reclinate orbital setae $)=1.00 / 0.82-1.00, \mathrm{dcp}($ distance between ipsilateral dorsocentral setae/distance between anterior dorsocentral setae $)=1.05 / 0.75-1.06$, sctlp $($ distance between ipsilateral scutellar setae/distance between apical scutellar setae $)=1.05 / 1.00-1.22, \mathrm{C}(2$ nd costal section between subcostal break and $\mathrm{R}_{2+3} / 3 \mathrm{rd}$ costal section between $\mathrm{R}_{2+3}$ and $\mathrm{R}_{4+5}$ ) $=1.59 / 1.56-1.91$, 4c (3rd costal section between $\mathrm{R}_{2+3}$ and $\mathrm{R}_{4+5} / \mathrm{M}_{1}$ between $\mathrm{r}-\mathrm{m}$ and $\left.\mathrm{dm}-\mathrm{cu}\right)=$ $1.46 / 1.33-2.00,4 \mathrm{v}\left(\mathrm{M}_{1}\right.$ between $\mathrm{dm}-\mathrm{cu}$ and wing margin/ $\mathrm{M}_{1}$ between $\mathrm{r}-\mathrm{m}$ and $\left.\mathrm{dm}-\mathrm{cu}\right)=2.18 / 2.13-3.13,5 \times\left(\mathrm{CuA}_{1}\right.$ between $\mathrm{dm}$-cu and wing margin/dm-cu between $\mathrm{M}_{1}$ and $\left.\mathrm{CuA}_{1}\right)=1.20 / 1.00-1.46$, ac (3rd costal section between $\mathrm{R}_{2+3}$ and $\mathrm{R}_{4+5}$ /distance between distal ends of $\mathrm{R}_{4+5}$ and $\mathrm{M}_{1}$ ) $=3.20 / 2.55-3.09, \mathrm{M}\left(\mathrm{CuA}_{1}\right.$ between $\mathrm{dm}-\mathrm{cu}$ and wing mar$\mathrm{gin} / \mathrm{M}_{1}$ between $\mathrm{r}-\mathrm{m}$ and dm-cu $)=0.21 / 0.22-0.24$.

Female. Head, thorax, legs and wings as in male.

Terminalia (Figs 10D, E, S3D, E): Sternite VII slightly concave on caudal margin. Epiproct nearly entirely pubescent; hypoproct laterally with a pair of small patches of pubescence. Oviscapt with 1-2 peg-like ovisensillum(a) on submedial surface.

Measurements (range in 59 paratypes, in $\mathrm{mm}$ ): $\mathrm{BL}$ $=1.75-2.05, \mathrm{ThL}=0.80-0.87, \mathrm{WL}=1.43-1.73, \mathrm{WW}=$ 0.70-0.80.

Indices (range in $5+$, or less if noted, paratypes, in ratio): $\mathrm{FW} / \mathrm{HW}=0.51-0.66, \mathrm{ch} / \mathrm{o}=0.25-0.42$, prorb $=0.76-$ $0.86(29), \mathrm{rcorb}=0.16-0.24(3+), \mathrm{vb}=0.20-0.26, \mathrm{dcl}$ 


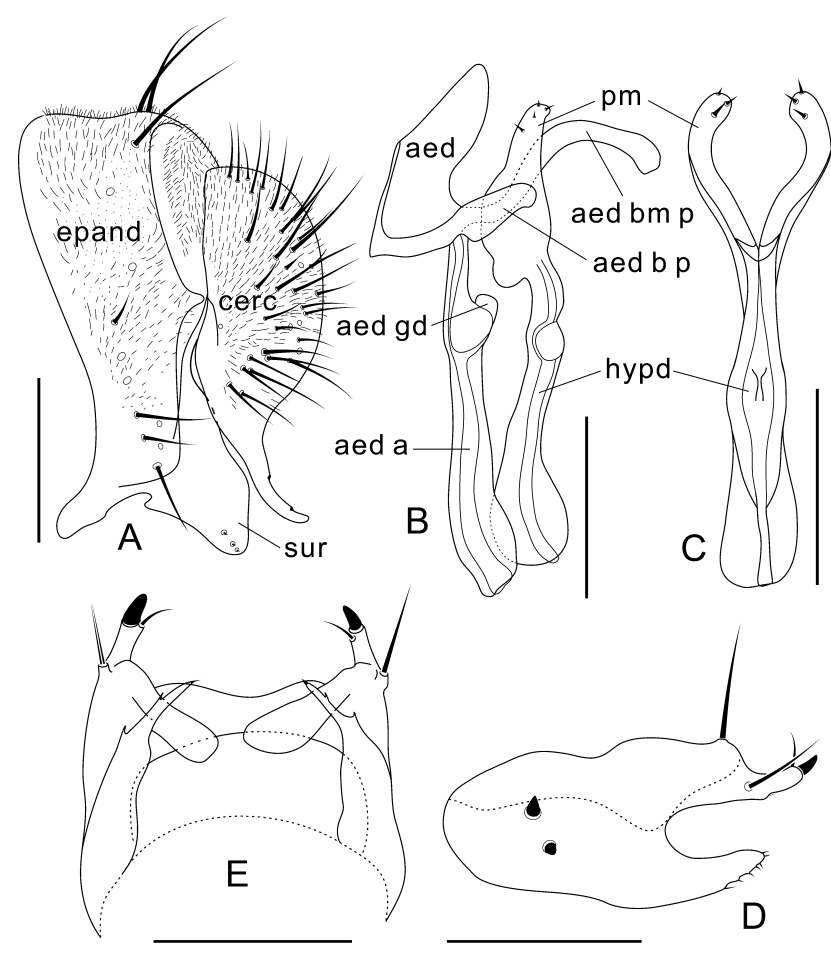

Fig. 10. Male and female terminalia of Colocasiomyia rostrata Shi \& Gao, sp. n. (o paratype \#02712, q paratype \#02724). A periphallic organs (lateral view); B - phallic organs (lateral view); C - hypandrium and parameres (ventral view); D - oviscapt (latera view); E - oviscapt (ventral view). Abbreviations: aed - aedeagus, aed $\mathrm{a}$ - aedeagal apodeme, aed b $\mathrm{p}$ - aedeagal basal process, aed bm $\mathrm{p}$ - aedeagal basomedial projection, aed gd - aedeagal guide, cerc - cercus, epand - epandrium, hypd - hypandrium, pm - paramere, sur - surstylus. Scale bars: $0.1 \mathrm{~mm}$.

$=0.58-0.71$, presctl $=0.63-0.72$, sctl $=0.57-0.66$, sterno $=0.54-0.71$, orbito $=0.86-1.60, \mathrm{dcp}=0.86-1.02$, sctlp $=$ $0.96-1.30, \mathrm{C}=1.38-1.61,4 \mathrm{c}=1.39-1.52,4 \mathrm{v}=1.91-2.19$, $5 \mathrm{x}=1.10-1.50, \mathrm{ac}=2.91-3.30, \mathrm{M}=0.21-0.26$.

Type material. Holotype, ô (\#02705), INDONESIA: West Sumatra, Lembah Anai, $0^{\circ} 28^{\prime} 55.3^{\prime \prime} \mathrm{S}, 100^{\circ} 20^{\prime} 17.7^{\prime \prime} \mathrm{E}, 250 \mathrm{~m}$ a.s.1., 9.xii.2004, ex Homalomena sp.L c.f. megalophylla (K.T. Takano) (MZB). Paratypes: INDONESIA: 21 $\hat{\jmath}, 24$ + (\#02706-50) (10^,

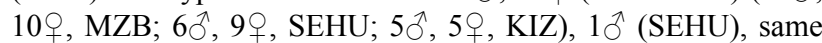
data as holotype; 1ㅇ, West Sumatra, Bukit Punai, 8.xii.2004, ex Homalomena sp.BP (Fig. S13) (K.T. Takano) (SEHU).

Type locality. West Sumatra, Lembah Anai, $0^{\circ} 28^{\prime} 55.3^{\prime \prime} \mathrm{S}$, $100^{\circ} 20^{\prime} 17.7^{\prime \prime} \mathrm{E}, 250 \mathrm{~m}$.

Etymology. Refers to the basal, long, beak-like projection of the aedeagus.

Distribution. Indonesia (Sumatra).

Remarks. This species is the first to branch off within the toshiokai group in the cladogram having resulted from the present study (Fig. 9). In addition, it is unique in having many species-specific, diagnostic characters among the members of this species group.

\section{Key to species of the Colocasiomyia toshiokai species group}

1 Foreleg tarsomere II apically with 3 long, stout spines (Fig $8 \mathrm{~A})$.

- Foreleg tarsomere II apically with 1 long and many small, tooth-like spines (Figs 8B, C, S2C, D, I, J, O) .
2 Additional pair of dorsocentral setae present 3

Additional pair of dorsocentral setae absent........................ 4

3 Surstylus apically round (Fig. 2B in Sultana et al., 2002); paramere half as long as aedeagus; aedeagus apically narrow in lateral view (Fig. S1M-O).

C. xanthogaster Yafuso \& Okada

- Surstylus apically triangular (Fig. 2C in Sultana et al., 2002); paramere $2 / 3$ as long as aedeagus; aedeagus apically thick (Fig. 3E in Sultana et al., 2002)

C. nigricauda Sultana \& Toda

4 Acrostichal setulae in 4 rows; foreleg tarsomere II slightly shorter than tarsomeres III and IV combined; antennal first flagellomere without small pouch on inner surface (Fig. 3A); surstylus and ventral elongation of cercus narrower than ventral elongation of epandrium (Fig. 2A in Sultana et al., 2002); aedeagus basally without beak-like projection (Fig. 3A in Sultana et al., 2002); oviscapt with small patch of pubescence (Fig. 5A in Sultana et al., 2002)............. . toshiokai (Okada)

- Acrostichal setulae in 2 rows; foreleg tarsomere II slightly longer than tarsomeres III and IV combined; antennal first flagellomere with small pouch on inner surface (Fig. 3D); surstylus and ventral elongation of cercus broader than ventral elongation of epandrium (Fig. 2D in Sultana et al., 2002); aedeagus basally with beak-like projection (Fig. 4A in Sultana et al., 2002); oviscapt without pubescence (Fig. 5D in Sultana et al., 2002) ........... erythrocephala Sultana \& Toda

5 Antennal aristal branches minute (Fig. 3F); thoracic pleura entirely dark brown; costal setae in middle row all weak, trichoid; long spine on foreleg tarsomere II thin, not sulcate (Fig. 8B); postpronotal lobe with approximately 10 setae nearly equal in thickness; oviscapt apically bilobed (Figs 10D, S3E) .............................. C. rostrata Shi \& Gao, sp. n.

- Longest branch of arista as long as prominent setae on pedicel (Fig. 3E); thoracic pleura largely (at least anepisternum and anepimeron) pale yellow; costa with apically blunt, heavy, peg-like setae interspersed between weak, trichoid ones in middle row; long spine on foreleg tarsomere II thick, sulcate (Figs 8C, S2O); postpronotal lobe with 2 prominent setae and 2-3 short setulae; oviscapt apically not bilobed (Fig. 5E in Sultana et al., 2002) ............. C. heterodonta Yafuso \& Okada

\section{Reproductive ecology}

Fig. 11 shows almost all the data on the composition of Colocasiomyia flies collected from individual inflorescences of Homalomena and Aglaonema in Vietnam, Malaysia and Indonesia. In lowlands of West Java, host inflorescences were usually occupied by two species of the toshiokai group, C. xanthogaster (Light form) and C. heterodonta (Form I), with baechlii-group species occasional cohabitants. In the Bogor Botanical Garden, C. xanthogaster tended to be more abundant than $C$. heterodonta on individual inflorescences of Homalomena, while the opposite was recorded on Aglaonema inflorescences. In the highlands of West Java, however, Homalomena inflorescences were almost monopolized by $C$. heterodonta. In Sarawak and Sabah, inflorescences of various Homalomena species were shared by another pair of species, C. nigricauda and C. heterodonta (Form II), of which the former was more abundant on all the host species studied except $H$. matangae. However, inflorescences of H. lambirensis in Lambir, which was misidentified as $H$. propinqua Schott by Kumano \& Yamaoka (2006) and Kumano-Nomura \& Yamaoka (2009) (Wong \& Boyce, 2017), were monopolized by 


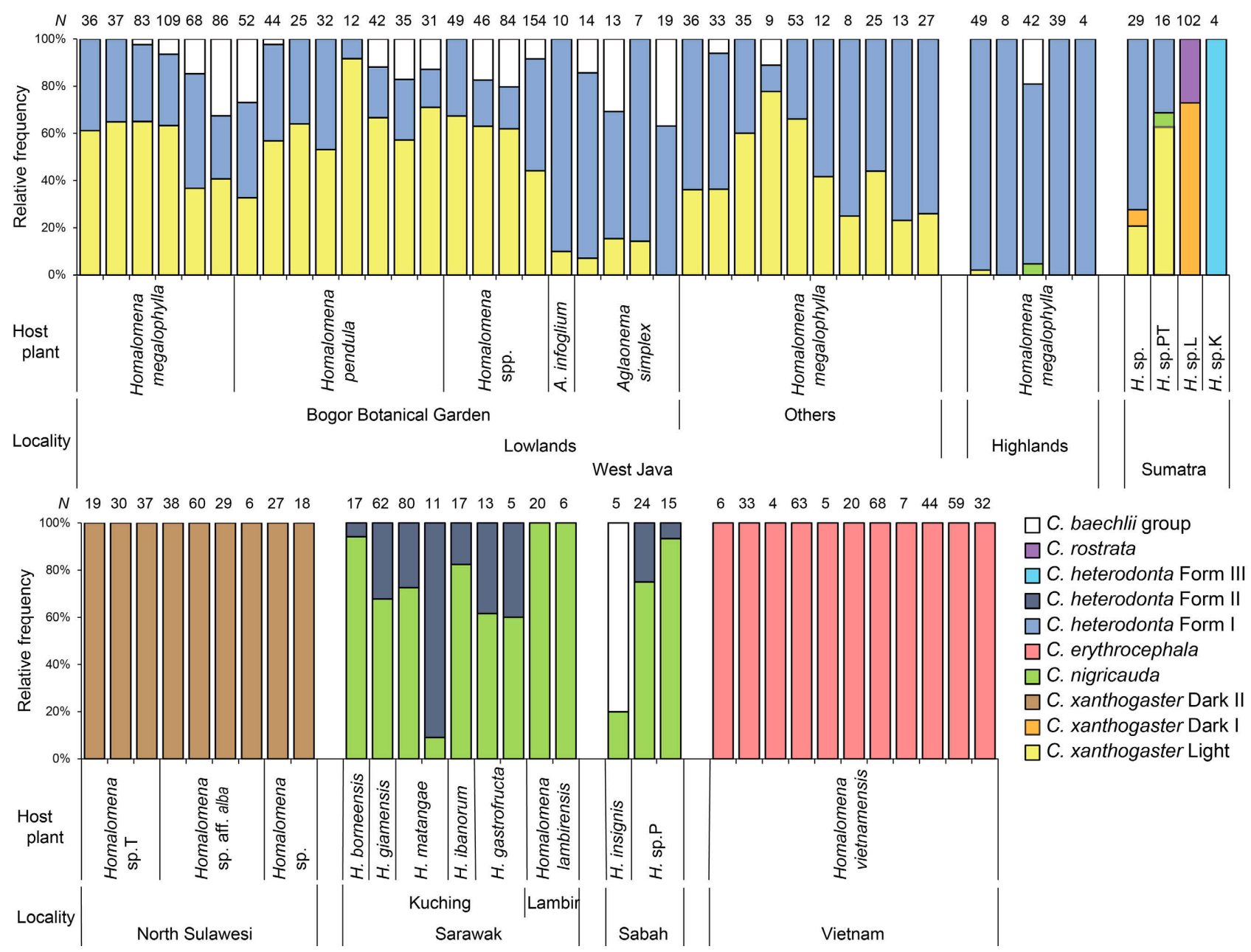

Fig. 11. Relative frequencies of Colocasiomyia species collected from individual inflorescences of various Homalomena and Aglaonema species in Vietnam, Malaysia and Indonesia.

C. nigricauda. In North Sulawesi and Vietnam, Homalomena inflorescences were monopolized by C. xanthogaster (Dark II form) and C. erythrocephala, respectively. In Sumatra there is the highest species richness of the toshiokai group, with three species including two Forms of $C$. heterodonta and two colour forms of $C$. xanthogaster. These species/forms used different Homalomena species as hosts in different combinations: a Homalomena inflorescence in Padang Panjang, West Sumatra was shared by C. heterodonta Form I, C. xanthogaster Light form and C. xanthogaster Dark I form, an inflorescence of $H$. sp.PT in Sungai Penuh-Tapan, West Sumatra by C. heterodonta Form I, C. xanthogaster Light form and C. nigricauda, an inflorescence of $H$. sp.L c.f. megalophylla in Lembah Anai, West Sumatra by $C$. rostrata and C. xanthogaster Dark I form and an inflorescence of $H$. sp.K on Mt. Kerinci, Jambi monopolized by $C$. heterodonta Form III.

Fig. 12 shows the distribution of Colocasiomyia eggs and larvae over the spadix of host inflorescences/infructescences collected in West Java. The eggs were counted on each $1 \mathrm{~cm}$ section of the pistillate and staminate regions from the border of the two regions. However, the larvae were counted separately only for each of the pistillate and staminate regions, because they were very actively mov- ing. In lowland West Java where C. xanthogaster (Light form) and $C$. heterodonta (Form I) cohabited in the same host inflorescences (Fig. 11), both species laid their eggs in the narrow spaces between pistils and/or staminodes mainly on the middle to upper portion of the pistillate region of Homalomena inflorescences, but $C$. heterodonta sporadically oviposited also on the basal border zone composed of relatively large, interstice staminodes in the staminate region. In the highlands where inflorescences of $H$. megalophylla collected on Mt. Halimun were almost monopolized by $C$. heterodonta (Fig. 11), the eggs of this species were found mainly on the pistillate middle portion to the staminate basal portion, but also sporadically on the staminate upper portions of the inflorescence. On an inflorescence of Aglaonema pictum (Roxb.) Kunth. in the Bogor Botanical Garden, which was visited by both $C$. xanthogaster and $C$. heterodonta, the eggs of only $C$. heterodonta were found and more abundant on the staminate lower portion than on the pistillate region. On Homalomena infructescences at Stage IV (Fig. 1B), Colocasiomyia larvae were found. Within an infructescence of $H$. pendula collected from the Bogor Botanical Garden, larvae (2nd and 3rd instars) of $C$. xanthogaster were observed feeding mostly on exudates in the pistillate region, while those of $C$. heterodonta fed on 


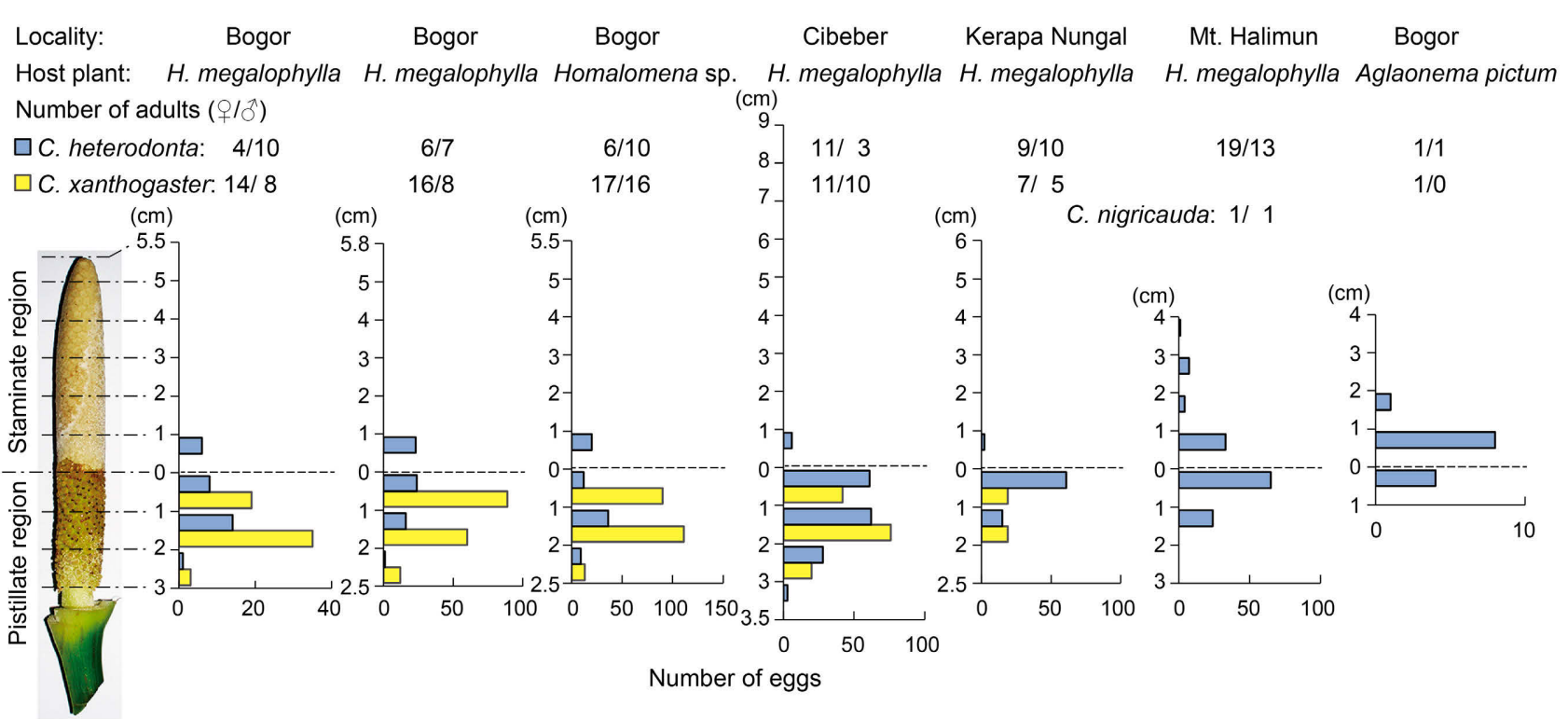

Homalomena megalophylla

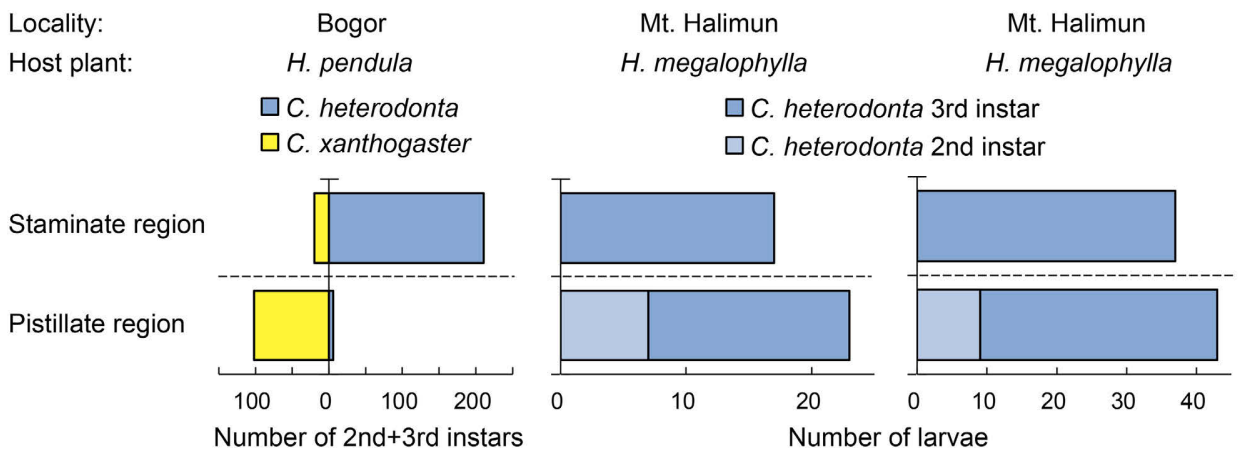

Fig. 12. Distribution of Colocasiomyia eggs and larvae over the spadix of inflorescences/infructescences of Homalomena and Aglaonema collected in West Java.

decaying tissues in the staminate region. Only $C$. heterodonta larvae were found in Stage-IV infructescences of $H$. megalophylla collected on Mt. Halimun: 2nd instars were restricted to the pistillate region and 3rd instars were recorded in both pistillate and staminate regions. However, neither larvae nor puparia (or empty puparial capsules) were found in any of the infructescences at Stage V. This implies that full-grown larvae of the toshiokai group leave their host infructescence via the decayed and exposed apex portion of the staminate region and pupate elsewhere. Some larvae showed skipping behaviour in the laboratory. Actually, larvae of C. alocasiae (Okada, 1975) of the cristata group were observed "popping out" of host infructescence and pupating elsewhere by Yafuso (1993).

Inflorescences/infructescences of $H$. lambirensis in Lambir, Sarawak were monopolized by $C$. nigricauda, the closest relative of $C$. xanthogaster. To determine the distribution of $C$. nigricauda immature stages (eggs, 1st and 2nd instars) on the spadix, spadices of inflorescences (Stage II) and young infructescences (Stage III and early IV) were separated into seven parts: upper $1 / 3$, middle $1 / 3$ and lower $1 / 3$ of staminate region, intermediate sterile region, and upper $1 / 3$, middle $1 / 3$ and lower $1 / 3$ of pistillate region. However, spadices of infructescences at late Stage IV, with 3rd instar larvae, were separated into three parts: stami- nate, intermediate and pistillate regions. There is a distinct intermediate region composed only of staminodes between the staminate and the pistillate regions on the spadix of $H$. lambirensis (Fig. 1b in Kumano \& Yamaoka, 2006). Eggs were laid mostly on the pistillate and intermediate regions, but also sporadically on the staminate region; 1st instar larvae were recorded mainly on the pistillate region, being most abundant on its lower $1 / 3$, but also sporadically on the intermediate and the staminate regions; 2nd instar larvae were recorded on the basal pistillate and intermediate region, rarely on the basal staminate region; 3rd instar larvae were recorded on the pistillate and staminate regions (Fig. 13).

Thus, when the two species, C. xanthogaster and $C$. heterodonta, cohabit inflorescences/infructescences of the same host plant, a slight difference was recorded in their utilization of the spadix for breeding. Although both species mainly used the pistillate region for oviposition and as a source of food for young larvae, $C$. heterodonta had a slightly wider niche in also sporadically using the basal staminate region. This difference, which is reported on the basis of incomplete data by Yafuso \& Okada (1990), is confirmed by the data collected in the present study. Furthermore, the present study suggests spatio-temporal separation of the feeding sites of the older larvae between these 


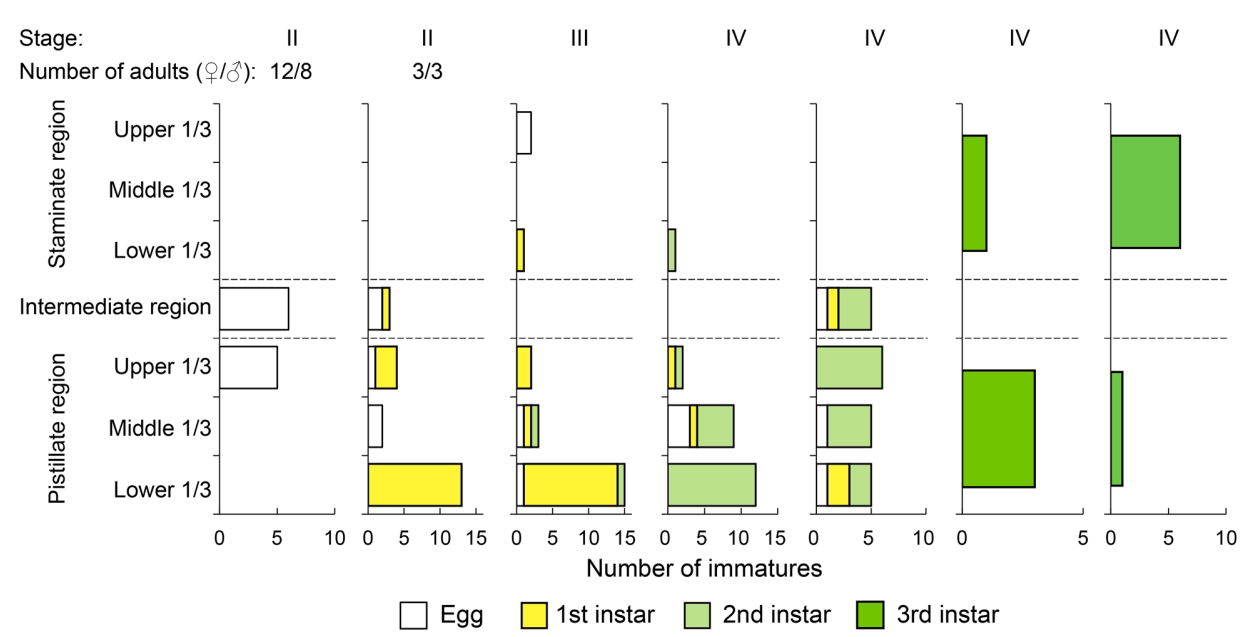

Fig. 13. Distribution of Colocasiomyia nigricauda eggs and larvae over the spadix of inflorescences/infructescences of Homalomena lambirensis collected in Lambir, Sarawak.

two species. Larvae of $C$. heterodonta may first move from the pistillate region to the staminate region and feed there on the decaying stamens. Larvae of C. xanthogaster may follow them, or complete their growth within the pistillate region. Although much more data are needed to reveal the interspecific differences in larval food habits, it can be said that $C$. xanthogaster is more pistilicolous and $C$. heterodonta more stamenicolous. Good examples of breeding niche separation in two cohabiting species are reported for some species pairs of the cristata group: one species uses exclusively the pistillate region for oviposition and larval development and pupates within the infructescence chamber, whereas the other uses mostly the staminate region and pupates elsewhere (Carson \& Okada, 1980; Honda-Yafuso, 1983; Toda \& Okada, 1983; Okada \& Yafuso, 1989; Yafuso, 1994). In comparison to these species, the niche separation between $C$. xanthogaster and $C$. heterodonta is slight and both species do not pupate in the host infructescence. Another case of slight niche separation is reported for two undescribed species, $C$. sp. 1 aff. sulawesiana and $C$. sp. 2 aff. sulawesiana, of the cristata group: both are principally pistilicolous and pupate within the host infructescence, but the two species show the different distributions of the adult flies within the host inflorescences and consequently oviposit on different parts of the spadix (Takano et al., 2012). In this case, one species (sp. 1) is also more pistilicolous than the other (sp. 2). When two Colocasiomyia species cohabit inflorescences/infructescences of the same Araceae host plant, breeding niche separation along the axis of the spadix seems to be a general pattern, probably resulting from convergence (e.g., parallel evolution) in different lineages. In relation to this niche separation, cohabiting species show different reproductive strategies in terms of a trade-off in "egg size vs. number": the stamenicolous species lay "more smaller eggs" than the pistilicolous species (Fartyal et al., 2013). The difference in this trade-off between $C$. xanthogaster and $C$. heterodonta is consistent with the general pattern, though smaller than in other pairs the niche separation of which is more marked (Fartyal et al., 2013).

\section{Flower-visiting behaviour}

Fig. 14 shows changes in the temperature of the pistillate and staminate regions of the two inflorescences of $H$. megalophylla and $H$. pendula recorded over the course of flowering, which lasted for two days, along with records of the important flowering events and behaviour of Colocasiomyia flies. The extent of heat generation by the inflorescence is expressed in terms of the differences between the pistillate $\left(T_{p}\right)$ or staminate $\left(T_{s}\right)$ temperatures and the ambient air temperature $(T)$. The general pattern in the flowering process and fly behaviour was almost identical on the two host plants. The heat generation was detected only in the staminate region of both species of plants. $T_{s}$ began to be higher than $T$ from dusk or early in the night of the day before anthesis, and the difference became about $1^{\circ} \mathrm{C}$ in the middle of the night. Synchronized with this increase in temperature was a loosening of the spathe. The dramatic process of anthesis started in the dark around 4:00 (in 24-hour notation; in November, for H. megalophylla) or 4:30 (in August, for $H$. pendula) in synchronization with the distinct increase in temperature recorded in the staminate region. The spathe became fully open within 30-60 min, but no Colocasiomyia flies visited the inflorescence in the dark. Around dawn at 4:50 or 5:20, $T$ s was 5 and $9^{\circ} \mathrm{C}$ higher than $T$ in $H$. megalophylla and $H$. pendula, respectively, and the inflorescence started to emit an odour. Soon after that, around sunrise (5:25 in November and 6:05 in August), Colocasiomyia flies successively visited the inflorescence of $H$. megalophylla from 5:20 to 5:45 and that of $H$. pendula from 5:40 to $6: 30$ when $T_{s}$ peaked at about $38^{\circ} \mathrm{C}$, which was $14^{\circ} \mathrm{C}$ higher than $T$, and there was a strong emission of odour. $T_{p}$ was only 2 or $3^{\circ} \mathrm{C}$ higher than $T$ during this period, which could have been caused by the conduction of heat from the staminate region. The flies alighted on the spathe or the staminate region but immediately moved to the pistillate region. Thereafter, $T_{s}$ gradually decreased, but remained about $5^{\circ} \mathrm{C}$ higher than $T$ at 7:30 in H. megalophylla or at 8:00 in H. pendula; the flies stayed in the pistillate region, mostly on the rear of its upper portion, sometimes ovipositing on the upper half of 
pistillate region and/or attempting to mate. The difference between $T_{s}$ and $T$ decreased to about $2^{\circ} \mathrm{C}$ from 9:00 in $H$. megalophylla or $1^{\circ} \mathrm{C}$ from 9:30 in $H$. pendula, and then remained relatively constant during the daytime; the flies seemed to be resting together on the rear of the inner wall of the spathe surrounding the pistillate region. In the evening, the flies resumed activity, feeding exclusively around the border zone between the pistillate and staminate regions, ovipositing on the pistillate region and in the border zone and mating; these activities continued throughout the night. The second increase in the $T_{s}-T$ temperature was recorded from 3:30 in both inflorescences, though it was less pronounced in H. megalophylla. This coincided with the spathe beginning to close and pollen release. Colocasiomyia flies successively left the inflorescence of $H$. megalophylla between 4:10 and 5:05 and that of $H$. pendula between 5:15 and 5:40. Although a few flies left the inflorescence of $H$. megalophylla during the middle of the night, this may have been due to disturbance or the effect of the headlamp used for nighttime observation: in the case of the $H$. pendula inflorescence, which was not observed at night, the same number of Colocasiomyia flies that visited the inflorescence in the previous morning left together the following day. There was no longer a difference between $T_{s}$ and $T$ recorded around 8:00 to 10:00, and by this time the spathe was completely closed, leaving the front-side, middle to upper portion of the staminate region uncovered; this exposed portion of the staminate region gradually decreased in area and finally only the apical portion remained exposed.

The two species of Homalomena studied are protogynous like other Araceae plants (Mayo et al., 1997): the female phase (stigma receptivity) of the inflorescence precedes the male phase (anther dehiscence). The first thermogenesis occurred in the female phase and was intimately associated with emission of a strong odour and the attraction of Colocasiomyia flies. Some studies have shown histologically that the generation of heat is associated with the volatilization of floral scent molecules (Skubatz et al., 1995; Skubatz \& Kunkel, 1999) and that Colocasiomyia flies are attracted to specific volatiles (Miyake \& Yafuso, 2003, 2005). In the present study, Colocasiomyia flies were observed immediately moving to the pistillate region and remaining there after alighting on the spathe or the staminate region. This behaviour would enable them to avoid exposure to the high temperature (about $38^{\circ} \mathrm{C}$ at the peak) conditions in the staminate region at this phase, as suggested by Ivancic et al. (2004): the pistillate temperature was about $12^{\circ} \mathrm{C}$ lower than the staminate temperature even at the peak of heat generation (Fig. 14). The second thermogenesis corresponded to the male phase and was synchronized with the spathe closing followed by pollen release and the flies leaving. Closing of the spathe stimulates the flies to crawl up from the pistillate region to the staminate region to avoid being imprisoned within the closed inflorescence chamber (cf. Bröderbauer et al., 2012). Then, the flies are dusted with pollen grains released in the staminate region and ultimately leave the inflorescence and then search for and are attracted by surrounding female-phase inflorescences. In the pollen-releasing phase, stingless bees were often observed visiting the inflorescence to collect pollen, even after the spathe was completely closed, but never entered the pistillate region. Thus, $C$. heterodonta and $C$. xanthogaster seem to be the most effective, specific pollinators of $H$. megalophylla and $H$. pendula, in their response to the characteristic flowering-events related to thermogenesis in the female and male phases. However, their efficiency as pollinators should be evaluated by field bagging experiments.

\section{Plant-pollinator interactions in Homalomeneae: a short review}

Homalomena is a large genus with more than 350 described and formally undescribed species (Boyce et al., 2010). Contrary to our observations of possible fly-pollination in $H$. megalophylla and $H$. pendula, both of which belong to the Homalomena section (sensu Wong et al., 2016), in Java, beetle-pollination is strongly suggested for H. lambirensis (Kumano \& Yamaoka, 2006), H. giamensis (Tung et al., 2010) and six other Homalomena species (Hoe et al., 2016) in Sarawak, Malaysian Borneo. Although these Homalomena species attract not only beetles but also Colocasiomyia flies, Kumano \& Yamaoka (2006) report pollen only attached to the bodies of two beetle species, Parastasia bimaculata Guerin (Scarabaeidae) and Dercetina sp. (Chrysomelidae), and Tung et al. (2010) and Hoe et al. (2016) report that only Parastasia species behave as possible effective pollinators of their host plants. It seems that species in the Homalomena and the Chamaecladon sections (sensu Wong et al., 2016) tend to be pollinated by Colocasiomyia flies, whereas species in the Cyrtocladon section (sensu Wong et al., 2016) tend to be pollinated by Scarabaeidae, Chrysomelidae and Hydrophilidae beetles (Wong et al., 2013; Hoe et al., 2016).

Chartier et al. (2014) categorize the genus Homalomena as plants "pollinated by fly and beetle", and its closely related genera Philodendron as those "pollinated by beetle" and Furtadoa as those "pollinated by fly". Mapping these pollination interaction types on a phylogenetic tree, they inferred that beetle pollination would have been the ancestral state for these related taxa.

The diurnal timing of anthesis varies among these aroid plants. Inflorescences of "beetle-pollinating" Philodendron species open in the evening and attract beetles at dusk (e.g., Gottsberger et al., 2013), whereas "beetlepollinating" Homalomena species begin flowering in the morning (Kumano \& Yamaoka, 2006; Tung et al., 2010; Hoe et al., 2016) as well as other "fly-pollinating" Homalomena species, $H$. megalophylla and $H$. pendula (the present study), and Furtadoa sumatrensis M. Hotta (Mori \& Okada, 2001), which attract Colocasiomyia flies in the early morning when drosophilid flies are active. As for the tribe Schismatoglottideae, Low et al. (2016) report that Aridarum nicolsonii Bogner, Phymatarum borneense M. Hotta and Schottarum sarikeense (Bogner \& M. Hotta) P.C. Boyce \& S.Y. Wong are pollinated by Colocasiomyia flies and that the first and the second species bloom at dawn 

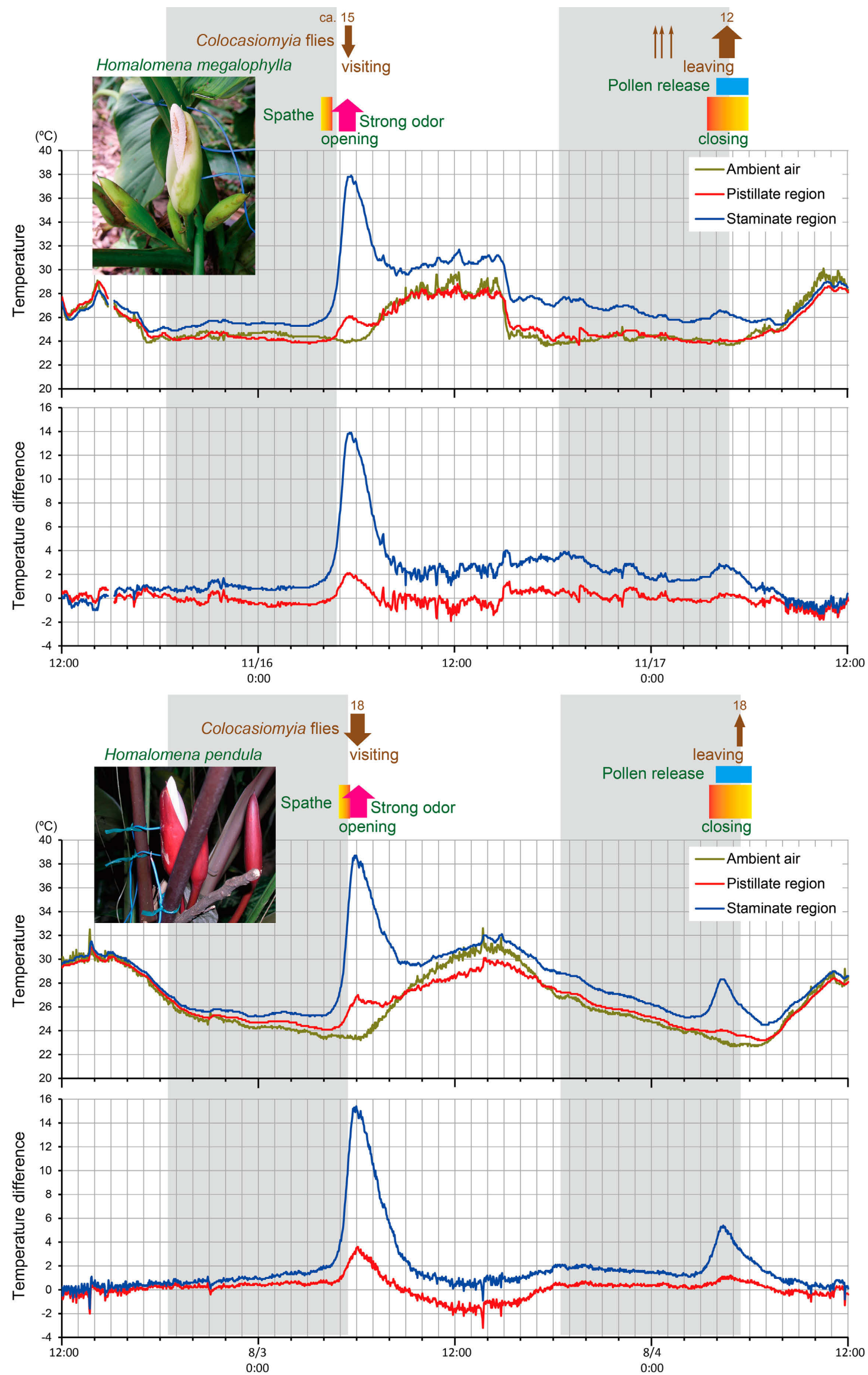

Fig. 14. Flowering-events, especially temperature changes recorded in the pistillate and staminate regions of spadix, and behaviour of Colocasiomyia flies observed during the flowering of inflorescences of Homalomena megalophylla (upper) and $H$. pendula (below) in the Bogor Botanical Garden, West Java. 
whereas the third species flowers at dusk. They state: "It seems that Schismatoglottideae and Homalomeneae tend to flower at dawn in the Old World tropics but related taxa in the Neotropics flower at dusk. This requires further investigation."

Not only the timing of anthesis but also other floral traits vary among aroid plants in relation to pollinator types. Gibernau et al. (2010) investigated 68 species of Araceae and found correspondence between pollinator types (i.e., bee-, fly- or beetle-pollination) and floral traits, such as pollen volume and number, the number of female flowers and flower sexual types (unisexual or bisexual). Differences in such floral syndromes are reported between "beetlepollinating" and "fly-pollinating" species even within the genus Homalomena.

Grayum (1986) report that the texture of Araceae pollen would have differentiated in adaptation to different types of pollinators: echinate (i.e., spiny) pollen is more effective for attaching to the hairs or bristles of flies and bees, whereas sticky secretions from the stigma or inner surface of spathe help psilate (i.e., smooth and lacking ornamentation) pollen to attach to smooth, hard bodies of beetles. Sannier et al. (2009) infer that psilate and foveolate/reticulate pollen ornamentations are ancestral character states in Araceae, and that evolutionary shifts to fly pollination are probably followed by transitions towards echinate pollen. Pollen of all the species of the genus Schismatoglottis Zoll. \& Moritzi investigated is psilate, and Hoe \& Wong (2016) infer mixed pollination of Schismatoglottis baangongensis S.Y. Wong, Y.C. Hoe \& P.C. Boyce (tribe Schismatoglottideae, Araceae) by Cycreon beetles (Hydrophilidae) and Colocasiomyia aff. bogneri. Such mixed pollination may represent a transitional state in an evolutionary shift in pollinator type. In our observations, H. megalophylla (Fig. 1), H. pendula (Fig. S4), Homalomena sp. L cf. megalophylla (Fig. S6), H. sp. aff. alba (Fig. S7), Homalomena sp. T (Fig. S8) and Homalomena sp. K (Fig. S12) produced powdery pollen, although we did not investigate ultra-structure of the ornamentation on the pollen. On the other hand, H. lambirensis (Kumano \& Yamaoka, 2006) and another seven Homalomena species (Hoe et al., 2016) in Sarawak secrete resin in the staminate region before the male phase (Fig. S10A), which makes the pollen sticky (Fig. S10C).

The constriction in the spathe between the staminate and pistillate regions of the spadix is seen in many genera of Araceae (Bröderbauer et al., 2012; Wong et al., 2013). Spathe constriction facilitates effective pollination by specific insects (e.g., Takenaka, 2006; Bröderbauer et al., 2014) but restricts access by non-pollinators to the pistillate region (e.g., Takano et al., 2012) by functioning as a sieve (Low et al., 2016). The spathe is swollen below the constriction (Figs S5B, S9, S10). Such more or less closed spathal chamber serves as a safe mating arena for pollinators (Kumano-Nomura \& Yamaoka, 2009). In general, the space between the spathe and the spadix is the site where visiting insects feed, breed, mate and rest. Therefore, the size and shape of spathal chamber should be strongly related to pollinator type. Wong et al. (2013) infer that the constricted spathe is plesiomorphic for Homalomena and has been lost once in the clade comprising the Homalomena and the Chamaecladon sections. Our observations indicate that the spathe is not constricted in all the Homalomena species that produce powdery pollen (Figs 1, S2, S4-6, S10). Thus, the loss of the spathe constriction and reduction in spathal chamber space would have been caused by the pollinator shift from large-bodied beetles to small-bodied flies.

The resurrection of the genus Adelonema Schott (Wong et al., 2016), which is the former New World Homalomena and closely related to Philodendron, implies a necessity to reassess the phylogenetic context of plant-pollinator interactions in these related genera. Further studies on evolutionary changes in floral traits, such as diurnal time of flowering, pollen characters and spathe size and shape, along with the change in role of Colocasiomyia flies from commensalist to mutualist would shed more light on the entangled evolution of intimate pollination mutualisms between the flower-breeding fly genus and Araceae plants.

ACKNOWLEDGEMENTS. We thank P.C. Boyce for identifying the species of Homalomena; S.-I Tanabe, M.B. Lakim and M.B. Mohamed for their help with field work; Economic Planning Unit of Malaysian Government for research permissions (UPE: 40/200/19 SJ. 732 and UPE: 40/200/19 SJ.1194 and 1195) for the study in Sabah, Malaysia; L. Chong, T. Itioka and T. Nakashizuka for their help with field work in the Lambir Hills National Park, Sarawak, Malaysia, in accordance with the Memorandums of Understanding signed between the Sarawak Forestry Corporation (SFC, Kuching, Malaysia) and the Japan Research Consortium for Tropical Forests in Sarawak (JRCTS, Sendai, Japan) in November 2005, and under Sarawak Forestry Department Permission to Conduct Research on Biological Resources - Permit No. NCCD.907.4.4(J/d.7)-109 and Park Permit No. 50/2012; S. Hartini and other staff members of Zoology Division, Research Center for Biology-LIPI, Indonesia, for their help with field work in Java, Sulawesi and Sumatra under research permissions 5816/ SU/KS/2004 and 6967/SU/KS/2004; and B.T. Viet for his help with field work in Vietnam. We thank A. Kopp for linguistic review of the manuscript, N. Inari and N. Kobayashi for extracting DNA from some specimens, N.-N. Li for collecting some of the DNA sequences used in the present study, and R. He for assistance with SEM photography. Some specimens were collected by S.Y. Wong from Sarawak, Malaysia under Sarawak Forestry Department Permission to Conduct Research on Biological Resources - Permit No. NCCD.907.4.4(J/d.10)-219 and Park Permit No. 179/2014. This work was supported by NSFC (No. 31160429 , 31572238), the fund of the Ministry of Science and Technology of China (No. 2011FY120200 and 2012FY110800), JSPS KAKENHI Grants Numbers 15255006, 21570085, 24370033 and the 21 st Century Center of Excellence Program (E-01) of the Ministry of Education, Culture, Sports, Science and Technology, Japan.

\section{REFERENCES}

Boom R., Sol C.J.A., Salimans M.M., Jansen C.L., WertheimVANDILLEN P.M.E. \& VANDERNOORDAA J. 1990: Rapid and simple method for purification of nucleic acids. - J. Clin. Microbiol. 28: 495-503.

Bouckaert R., Heled J., Kühnert D., Vaughan T., Wu C.H., Xie D., Suchard M.A., Rambaut A. \& Drummond A.J. 2014: 
BEAST 2: A software platform for Bayesian evolutionary analysis. - PLoS Comput. Biol. 10: e1003537, 6 pp.

Boyce P.C., Wong S.Y., Jen A.T.P., Low S.E., Low S.L., Ng K.K. \& OoI I.H. 2010: The Araceae of Borneo - The genera. - Aroideana 33: 3-73.

BRNCIC D. 1983: Ecology of flower-breeding Drosophila. In Ashburner M., Carson H.L. \& Thompson J.N., Jr. (eds): The Genetics and Biology of Drosophila. Vol. 3d. Academic Press, London, pp. 333-382.

BröDerbauer D., Diaz A. \& Weber A. 2012: Reconstructing the origin and elaboration of insect-trapping inflorescences in the Araceae. - Am. J. Bot. 99: 1666-1679.

BröDerbauer D., Ulrich S. \& Weber A. 2014: Adaptations for insect-trapping in brood-site pollinated Colocasia (Araceae). - Plant Biol. 16: 659-668.

Carson H.L. \& Okada T. 1980: Drosophilidae associated with flowers in Papua New Guinea. I. Colocasia esculenta. - Kontyû 48: 15-29.

Chartier M., Gibernau M. \& Renner S.S. 2014: The evolution of pollinator-plant interaction types in the Araceae. - Evolution 68: $1533-1543$.

Cusimano N., Bogner J., Mayo S.J., Boyce P.C., Wong S.Y., Hesse M., Hetterscheid W.L.A., Keating R.C. \& French J.C. 2011: Relationships within the Araceae: Comparison of morphological patterns with molecular phylogenies. - Am. J. Bot. 98: 654-668.

Fartyal R.S., Gao J.J., Toda M.J., Hu Y.G., Takenaka T.K., Suwito A., Katoh T., Takigahira T. \& Y IN J.T. 2013: Colocasiomyia (Diptera: Drosophilidae) revised phylogenetically, with a new species group having peculiar lifecycles on monsteroid (Araceae) host plants. — Syst. Entomol. 38: 763-782.

Folmer O., Black M., Hoeh W., Lutz R. \& Vrijenhoek R. 1994: DNA primers for amplification of mitochondrial cytochrome $c$ oxidase subunit I for diverse metazoan invertebrates. - Mol. Mar. Biol. Biotechnol. 3: 294-299.

Gibernau M., Chartier M. \& Barabé D. 2010: Recent advances towards an evolutionary comprehension of Araceae pollination. In Seberg O., Petersen G., Barfod A.S. \& Davis I.I. (eds): Diversity, Phylogeny, and Evolution in the Monocotyledons. Aarhus University Press, Aarhus, pp. 101-104.

Gibert P., Moreteau B., Munjal A. \& David J.R. 1999: Phenotypic plasticity of abdominal pigmentation in Drosophila kikkawai: multiple interactions between a major gene, sex, abdomen segment, and growth temperature. - Genetica 105: $165-176$.

Gottsberger G., Silberbauer-Gottsberger I. \& Dötterl S. 2013: Pollination and floral scent differentiation in species of the Philodendron bipinnatifidum complex (Araceae). - Plant Syst. Evol. 299: 793-809.

Grayum M.H. 1986: Correlations between pollination biology and pollen morphology in the Araceae, with some implications for angiosperm evolution. In Ferguson I.K. \& Blackmore S. (eds): Pollen and Spores: Form and Function. Elsevier, London, pp. 313-327.

Hasegawa M., Kishino H. \& Yano T. 1985: Dating of the humanape splitting by a molecular clock of mitochondrial DNA. $-J$. Mol. Evol. 22: 160-174.

Hoe Y.C. \& Wong S.Y. 2016: Floral biology of Schismatoglottis baangongensis (Araceae) in West Sarawak, Borneo. - Plant Syst. Evol. 302: 1239-1252.

Hoe Y.C., Gibernau M., Maia A.C.D. \& Wong S.Y. 2016: Flowering mechanisms, pollination strategies and floral scent analyses of syntopically co-flowering Homalomena spp. (Araceae) on Borneo. — Plant Biol. 18: 563-576.
HondA-YAFUSO M. 1983: Interspecific relationship between synhospitalic Drosophilella species (Diptera, Drosophilidae) inhabiting Alocasia odora on Okinawa Is, Japan. - Kontŷ̂ 51: 520-527.

Ivancic A., Lebot V., Roupsard O., Garcia J.Q. \& OKpul T. 2004: Thermogenic flowering of taro (Colocasia esculenta, Araceae). - Can. J. Bot. 82: 1557-1565.

Kimura M.T., Toda M.J., Beppu K. \& Watabe H. 1977: Breeding sites of drosophilid flies in and near Sapporo, northern Japan, with supplementary notes on adult feeding habits. - Konty $\hat{u}$ 45: $571-582$.

Kobayashi N., Ohta Y., Katoh T., Kahono S., Hartini S. \& KATAKURA H. 2009: Molecular phylogenetic analysis of three groups of Asian Epilachnine ladybird beetles recognized by the female internal reproductive organs and modes of sperm transfer. - J. Nat. Hist. 43: 1637-1649.

Kumano Y. \& Yamaoka R. 2006: Synchronization between temporal variation in heat generation, floral scents and pollinator arrival in the beetle-pollinated tropical Araceae Homalomena propinqua. - Plant Species Biol. 21: 173-183.

Kumano-Nomura Y. \& Yamaoka R. 2009: Beetle visitations, and associations with quantitative variation of attractants in floral odors of Homalomena propinqua (Araceae). - J. Plant Res. 122: 183-192.

Kumar S., Stecher G. \& Tamura K. 2016: MEGA7: Molecular evolutionary genetics analysis version 7.0 for bigger datasets. - Mol. Biol. Evol. 33: 1870-1874.

Li N.N., Toda M.J., Fu Z., Li S.H. \& GaO J.J. 2014: Taxonomy of the Colocasiomyia gigantea species group (Diptera, Drosophilidae), with descriptions of four new species from Yunnan, China. - ZooKeys 406: 41-64.

Low S.L., Wong S.Y., OoI I.H., Hesse M., Stadler Y., SchonenBERGER J. \& BOYCE P.C. 2016: Floral diversity and pollination strategies of three rheophytic Schismatoglottideae (Araceae). - Plant Biol. 18: 84-97.

Mayo S.J., Bogner J. \& Boyce P.C. 1997: The Genera of Araceae. Royal Botanic Gardens, Kew, 370 pp.

McAlpine J.F. 1981: Morphology and terminology - Adults. In McAlpine J.F., Peterson B.V., Shewell G.E., Teskey H.J., Vockeroth J.R. \& Wood D.M. (eds): Manual of Nearctic Diptera. Vol. 1. Biosystematics Research Institute, Ottawa, pp. 9-63.

Miyake T. \& Yafuso M. 2003: Floral scents affect reproductive success in fly-pollinated Alocasia odora (Araceae). - Am. J. Bot. 90: 370-376.

Miyake T. \& Yafuso M. 2005: Pollination of Alocasia cucullata (Araceae) by two Colocasiomyia flies known to be specific pollinators for Alocasia odora. - Plant Species Biol. 20: 201-208.

MORI Y. \& OKADA H. 2001: Reproductive biology and pollen flow of a rheophytic aroid, Furtadoa sumatrensis (Araceae) in the Malesian wet tropics. - Plant Syst. Evol. 227: 37-47.

OKADA T. 1986: Estimation of the routes of synhospitalic distribution of the genus Drosophilella Duda (Diptera, Drosophilidae), with descriptions of three new species from Malaysia and Indonesia. - Proc. Jpn. Soc. Syst. Zool. 33: 32-39.

OKadA T. 1988: Taxonomic note on Colocasiomyia cristata de Meijere (Diptera, Drosophilidae) with generic synonymy. Proc. Jpn. Soc. Syst. Zool. 37: 34-39.

OKada T. 1990: Subdivision of the genus Colocasiomyia de Meijere (Diptera, Drosophilidae) with descriptions of two new species from Sulawesi and note on color adaptation of synhospitalic species. - Proc. Jpn. Soc. Syst. Zool. 42: 66-72.

Okada T. \& Yafuso M. 1989: The genus Colocasiomyia Duda (Diptera, Drosophilidae) from Sulawesi. - Proc. Jpn. Soc. Syst. Zool. 39: 48-55. 
Pons J., Barraclough T., Gomez-Zurita J., Cardoso A., Duran D., Hazell S., Kamoun S., Sumlin W. \& Vogler A. 2006: Sequence-based species delimitation for the DNA taxonomy of undescribed insects. - Syst. Biol. 55: 595-610.

Puillandre N., Lambert A., Brouillet S. \& Achaz G. 2012: ABGD, Automatic barcode gap discovery for primary species delimitation. - Mol. Ecol. 21: 1864-1877.

Ratnasingham S. \& Hebert P.D.N. 2007: BOLD: The Barcode of Life Data System (www.barcodinglife.org). - Mol. Ecol. Notes 7: 355-364.

Ratnasingham S. \& Hebert P.D.N. 2013: A DNA-based registry for all animal species: The Barcode Index Number (BIN) system. - PLOS ONE 8: e66213, 16 pp.

SAnNier J., BaKer W.J., Anstett M.-C. \& Nadot S. 2009: A comparative analysis of pollinator type and pollen ornamentation in the Araceae and the Arecaceae, two unrelated families of the monocots. - BMC Res. Notes 2: 145, 11 pp.

SHORROCKs B. 1982: The breeding sites of temperate woodland Drosophila. In Ashbumer M., Carson H.L. \& Thompson J.N., Jr. (eds): The Genetics and Biology of Drosophila. Vol. $3 b$. Academic Press, London, pp. 385-428.

Skubatz H. \& Kunkel D.D. 1999: Further studies of the glandular tissue of the Sauromatum guttatum (Araceae) appendix. - Am. J. Bot. 86: 841-854.

Skubatz H., Kunkel D.D., Patt J.M., Howald W.N., Hartman T.G. \& Meeuse B.J.D. 1995: Pathway of terpene excretion by the appendix of Sauromatum guttatum. - Proc. Natl. Acad. Sci. U.S.A. 99: 10084-10088.

Stamatakis A. 2006: RAxML-VI-HPC: Maximum likelihoodbased phylogenetic analyses with thousands of taxa and mixed models. - Bioinformatics 22: 2688-2690.

Sultana F., Toda M.J., Yafuso M., Lakim M.B., Mohamed M.B. \& CuONG N.M. 2002: A new species-group of the genus Colocasiomyia de Meijere (Diptera: Drosophilidae), with descriptions of two new species from eastern Malaysia and Vietnam. - Entomol. Sci. 5: 305-315.

Sultana F., Hu Y.G., Toda M.J., Takenaka K. \& Yafuso M. 2006: Phylogeny and classification of Colocasiomyia (Diptera, Drosophilidae), and its evolution of pollination mutualism with aroid plants. - Syst. Entomol. 31: 684-702.

Swofford D.L. 2003: PAUP*: Phylogenetic Analysis Using Parsimony (*and Other Methods), Version 4. Sinauer Associates, Sunderland, MA.

Takano K.T., Repin R., Mohamed D.M.B. \& Toda M.J. 2012: Pollination mutualism between two taxonomically undescribed Colocasiomyia species (Diptera: Drosophilidae) and their host, Alocasia macrorrhizos (Araceae), in Sabah, Borneo. - Plant Biol. 14: 555-564.

Takenaka K. 2006: Reproductive Ecology of the Genus Colocasiomyia (Diptera: Drosophilidae) and Pollination Mutualism with Araceae Plants. PhD Thesis, Hokkaido University, Sapporo, $74 \mathrm{pp}$.

Takenaka K., Yin J.T., Wen S.Y. \& Toda M.J. 2006: Pollination mutualism between a new species of the genus Colocasiomyia de Meijere (Diptera: Drosophilidae) and Steudnera colocasiifolia (Araceae) in Yunnan, China. — Entomol. Sci. 9: 79-91.
Toda M.J. 2018: DrosWLD-Species: Taxonomic Information Database for World Species of Drosophilidae. URL: http:// bioinfo.lowtem.hokudai.ac.jp/db/modules/stdb/index.php?ml lang=en (last accessed 24 May 2018).

Toda M.J. \& Lakim M.B. 2011: Genus Colocasiomyia (Drosophilidae: Diptera) in Sabah, Bornean Malaysia: High species diversity and use of host aroid inflorescences. - Entomol. Sci. 14: $262-270$.

ToDA M.J. \& OKaDA T. 1983: Ecological studies of floricolous Drosophilella in Burma with descriptions of three new species from Burma and the Philippines (Diptera, Drosophilidae). Kontyû 51: 169-184.

Tung L.S., Wong S.Y. \& Boyce P.C. 2010: Studies on Homalomeneae (Araceae) of Borneo VI: Homalomena giamensis, a new species from Sarawak, Malaysian Borneo, with observations on its pollination. - Aroideana 33: 202-211.

Watrous L.E. \& WheELER Q.D. 1981: The outgroup comparison method of character analysis. - Syst. Zool. 30: 1-11.

WittKopp P.J., CARroll S.B. \& Kopp A. 2003: Evolution in black and white: genetic control of pigment patterns in Drosophila. — Trends Genet. 19: 495-504.

Wong S.Y. \& Boyce P.C. 2017: Studies on Homalomeneae (Araceae) of Borneo XX: Homalomena lambirensis sp. nov. from Sarawak with well-recorded pollination biology. - Nordic J. Bot. 35: 557-562.

Wong S.Y., Tan P.J., Kiaw N.K., Othman A.S., Lee H.B., Ahmad F.B. \& Boyce P.C. 2013: Phylogeny of Asian Homalomena (Araceae) based on the ITS region combined with morphological and chemical data. - Syst. Bot. 38: 589-599.

Wong S.Y., Meerow A.W. \& Croat T.B. 2016: Resurrection and new species of the Neotropical genus Adelonema (Araceae: Philodendron Clade). - Syst. Bot. 41: 32-48.

YAfuso M. 1993: Thermogenesis of Alocasia odora (Araceae) and the role of Colocasiomyia flies (Diptera: Drosophilidae) as cross pollinators. - Environ. Entomol. 22: 601-606.

YAFuso M. 1994: Life history traits related to resource partitioning between synhospitalic species of Colocasiomyia (Diptera, Drosophilidae) breeding in inflorescences of Alocasia odora (Araceae). - Ecol. Entomol. 19: 65-73.

YAFuso M. \& OKADA T. 1990: Complicated routes of the synhospitalic pairs of the genus Colocasiomyia in Java, with descriptions of two new species (Diptera, Drosophilidae). - Esakia (Special issue No. 1): 137-150.

Yafuso M., Sultana F., Sasaki Y. \& Toda M.J. 2000: A new species of Colocasiomyia de Meijere (Diptera, Drosophilidae) from North Sulawesi, Indonesia. - Entomol. Sci. 3: 115-119.

Zhang W.X. \& Toda M.J. 1992: A new species-subgroup of the Drosophila immigrans species-group, with description of two new species from China and revision of taxonomic terminology. - Jpn. J. Entomol. 60: 839-850.

Received March 7, 2019; revised and accepted July 31, 2019 Published online October 17, 2019

Unpaginated supplementary material follows (Tables S1-S4, Figs S1-S13). 
Table S1. Summary of specimens used for COI sequencing, with GenBank accession numbers.

\begin{tabular}{|c|c|c|c|c|c|c|}
\hline $\begin{array}{l}\text { Species } \\
\text { group }\end{array}$ & Species & Form & $\begin{array}{c}\text { Voucher } \\
\quad \#\end{array}$ & Collection site & $\begin{array}{c}\text { Collection } \\
\text { date }\end{array}$ & $\begin{array}{c}\text { Accession } \\
\quad \#\end{array}$ \\
\hline \multirow[t]{2}{*}{ baechlii } & sp.1 aff. bogneri & & $\# 01311$ & Cikaniki, Gn. Halimun, West Java, Java, Indonesia & 1.i.2004 & KY404114 \\
\hline & sp.2 aff. bogneri & & $\# 01322$ & Bogor Botanical Garden, West Java, Java, Indonesia & 23.xii.2003 & KY404115 \\
\hline \multirow[t]{2}{*}{ cristata } & cristata & & $\# 01253$ & Bogor Botanical Garden, West Java, Java, Indonesia & 7.i.2004 & KY809851 \\
\hline & steudnerae & & \#01269 & Xishuangbanna Tropical Botanical Garden, Yunnan, China & 19.iii.2006 & KY404113 \\
\hline \multirow[t]{2}{*}{ zeylanica } & sp.4A aff. nepalensis & & $\# 05202$ & Cibodas, West Java, Indonesia & 24.xii.2003 & KY404117 \\
\hline & sp.5B aff. nepalensis & & \#05222 & Cikaniki, Gn. Halimun, West Java, Indonesia & $4-5 . x i .2009$ & KY404118 \\
\hline \multirow[t]{2}{*}{ gigantea } & gigantea & & $\# 01350$ & Bogor Botanical Garden, West Java, Indonesia & 9.i.2004 & KJ700882* \\
\hline & hailini & & \#01294 & Baihualing, Baoshan, Yunnan, China & ?.x.2014 & KU866357 \\
\hline \multirow[t]{38}{*}{ toshiokai } & xanthogaster & Light & $\# 01249$ & Cibeber, West Java, Java, Indonesia & 31.x.2009 & KU866349 \\
\hline & & & $\# 01285$ & Bogor Botanical Garden, West Java, Java, Indonesia & 2.i.2005 & KU866350 \\
\hline & & & $\# 01286$ & $\begin{array}{l}\text { Sungai Penuh } \rightarrow \text { Tapan alt } 700 \mathrm{~m} \text {, West Sumatra, Sumatra, } \\
\text { Indonesia }\end{array}$ & 7.xii. 2004 & KU866351 \\
\hline & & Dark I & \#01348 & Lembah Anai, alt250m, West Sumatra, Sumatra, Indonesia & 9.xii.2004 & KU866358 \\
\hline & & Dark II & $\# 02778$ & Tumokang, Dumoga Bone N. P., N. Sulawesi, Indonesia & 21.xii.2003 & KU866368 \\
\hline & & & \#02779 & Ditto & 21.xii.2003 & KU866369 \\
\hline & & & $\# 02803$ & Ditto & 21.xii.2003 & KU866370 \\
\hline & & & $\# 02804$ & Ditto & 21.xii.2003 & KU866371 \\
\hline & & & $\# 02826$ & Toraut, N. Sulawesi, Indonesia & 19.xii.2003 & KU866372 \\
\hline & & & $\# 02827$ & Ditto & 19.xii.2003 & KU866373 \\
\hline & & & \#02838 & Ditto & 19.xii.2003 & KU866374 \\
\hline & & & $\# 02839$ & Ditto & 19.xii.2003 & KU866375 \\
\hline & & & $\# 02856$ & Desa Tinoor, N. Sulawesi, Indonesia & 22.xii.2003 & KU866376 \\
\hline & & & $\# 02857$ & Ditto & 22.xii.2003 & KU866377 \\
\hline & & & $\# 02864$ & Ditto & 22.xii.2003 & KU866378 \\
\hline & & & $\# 02865$ & Ditto & 22.xii.2003 & KU866379 \\
\hline & nigricauda & & \#01239 & Bako, Sarawak, Borneo, Malaysia & 4.ii.2009 & KU866342 \\
\hline & & & $\# 01240$ & Poring, Sabah, Borneo, Malaysia & 12.iii,2008 & KU866343 \\
\hline & & & \#01246 & Cikaniki, Gn. Halimun, West Java, Java, Indonesia & 7.xi.2009 & KU866346 \\
\hline & heterodonta & I & $\# 01244$ & Cibeber, West Java, Java, Indonesia & 31.x.2009 & KU866344 \\
\hline & & & $\# 01245$ & Kerapa Nungal, West Java, Java, Indonesia & 31.x.2009 & KU866345 \\
\hline & & & $\# 01247$ & Cikaniki, Gn. Halimun, West Java, Java, Indonesia & 7.xi.2009 & KU866347 \\
\hline & & & \#01248 & Kerapa Nungal, West Java, Java, Indonesia & 31.x.2009 & KU866348 \\
\hline & & & \#01288 & $\begin{array}{l}\text { Sungai Penuh } \rightarrow \text { Tapan alt } 700 \mathrm{~m} \text {, West Sumatra, Sumatra, } \\
\text { Indonesia }\end{array}$ & 7.xii.2004 & KU866352 \\
\hline & & & \#01290 & Bogor, West Java, Java, Indonesia & 20.x.2004 & KU866354 \\
\hline & & & \#01291 & $\begin{array}{l}\text { Gn. Gede Pangarango, Salabintana, West Java, Java, } \\
\text { Indonesia }\end{array}$ & 1.i.2004 & KU866355 \\
\hline & & & \#01292 & Gn. Halimun, West Java, Java, Indonesia & 18.i.2004 & KU866356 \\
\hline & & II & \#01238 & Poring, Kinabalu Park, Sabah, Malaysia & 12.iii.2008 & KU866341 \\
\hline & & & \#01289 & Inobong, Crocker Range N. P., Sabah, Malaysia & 7.viii.2003 & KU866353 \\
\hline & & & $\# 02754$ & $\begin{array}{l}\text { Sugun Jawan, Kampung Giam, Siburan, Kuching, Sarawak, } \\
\text { Malaysia }\end{array}$ & 31.xii.2012 & KU866367 \\
\hline & & III & $\# 02751$ & Gn. Kerinci, Jambi, 1800-2000 m alt. Sumatra, Indonesia & 7.x.2004 & KU866365 \\
\hline & & & \#02752 & Ditto & 7.x.2004 & KU866366 \\
\hline & rostrata $\mathrm{sp} . \mathrm{n}$. & & $\# 02705$ & Lembah Anai, alt $250 \mathrm{~m}$, West Sumatra, Sumatra, Indonesia & 9.xii.2004 & KU866359 \\
\hline & & & \#02711 & Ditto & 9.xii.2004 & KU866360 \\
\hline & & & $\# 02712$ & Ditto & 9.xii.2004 & KU866361 \\
\hline & & & $\# 02724$ & Ditto & 9.xii.2004 & KU866362 \\
\hline & & & $\# 02725$ & Ditto & 9.xii.2004 & KU866363 \\
\hline & & & \#02726 & Ditto & 9.xii. 2004 & KU866364 \\
\hline
\end{tabular}

\footnotetext{
* Sequence determined by Li et al. (2014).
} 
Table S2. Result of the ABGD analysis.

\begin{tabular}{|c|c|c|c|c|}
\hline \multirow{3}{*}{$\begin{array}{c}\text { Prior intraspecific } \\
\text { divergence }(P)\end{array}$} & \multicolumn{4}{|c|}{ Automatic partition } \\
\hline & \multicolumn{2}{|r|}{ Initial } & \multicolumn{2}{|r|}{ Recursive } \\
\hline & Number of groups & Corresponding candidate species* & $\begin{array}{l}\text { Number of } \\
\text { groups }\end{array}$ & Corresponding candidate species* \\
\hline 0.0010 & 21 & Identical sequences & 21 & Identical sequences \\
\hline 0.0017 & 5 & rost, nigr, xant, hetr, (olig + poly $)$ & 6 & rost, nigr, xant, hetr, olig, poly \\
\hline 0.0028 & 5 & ditto & 6 & ditto \\
\hline 0.0046 & 5 & ditto & 6 & ditto \\
\hline 0.0077 & 5 & ditto & 5 & rost, nigr, xant, hetr, (olig+ poly) \\
\hline 0.0129 & 5 & ditto & 5 & ditto \\
\hline 0.0215 & 3 & rost $,($ nigr $+x a n t),($ hetr + olig + poly $)$ & 4 & rost, nigr, xant,$($ hetr + olig + poly $)$ \\
\hline 0.0359 & 4 & rost, nigr, xant, (hetr+olig+poly) & 4 & ditto \\
\hline 0.0599 & 1 & (rost + nigr $+x a n t+h e t r+o l i g+$ poly $)$ & 1 & $($ rost + nigr $+x a n t+h e t r+o l i g+$ poly $)$ \\
\hline
\end{tabular}

* Abrreviations for species names: rost, rostrata sp. n.; nigr, nigricauda; xant, xanthogaster; hetr, heterodonta; olig, oligodonta sp. n.; poly, polydonta sp. n. 
Table S3. Morphological comparison of the three forms of Colocasiomyia xanthogaster.

\begin{tabular}{|c|c|c|c|}
\hline Form & Light* & Dark I & Dark II \\
\hline Distribution & $\begin{array}{l}\text { West Java, West } \\
\text { Sumatra, West } \\
\text { Kalimantan, Sarawak }\end{array}$ & West Sumatra & North Sulawesi \\
\hline Abdominal tergites & $\begin{array}{l}\text { Pale yellow (female) } \\
\text { or pale brown (male; } \\
\text { Fig. S1A) }\end{array}$ & $\begin{array}{l}\text { Nearly entirely } \\
\text { dark gray to black } \\
\text { (Fig. S1B) }\end{array}$ & $\begin{array}{l}\text { Nearly entirely } \\
\text { dark gray to black } \\
\text { (Fig. S1C) }\end{array}$ \\
\hline $\begin{array}{l}\text { Dark patch on } \\
\text { apical portion of } \\
\text { inner surface of } \\
\text { foreleg tibia }\end{array}$ & Absent (Fig. S1A) & Present (Fig. S1B) & Present (Fig. S1C) \\
\hline $\begin{array}{l}\text { Space between } \\
\text { antennal sockets }\end{array}$ & $\begin{array}{l}\text { Broader than half of } \\
\text { socket width (Fig. } \\
\text { S1D) }\end{array}$ & $\begin{array}{l}\text { Narrower than half } \\
\text { of socket width } \\
\text { (Fig. S1E) }\end{array}$ & $\begin{array}{l}\text { Narrower than half } \\
\text { of socket width } \\
\text { (Fig. S1F) }\end{array}$ \\
\hline Facial carina & $\begin{array}{l}\text { As long as antennal } \\
\text { pedicel + first } \\
\text { flagellomere, slightly } \\
\text { narrower than first } \\
\text { flagellomere, more } \\
\text { or less truncately } \\
\text { demarcated below } \\
\text { (Fig. S1D) }\end{array}$ & $\begin{array}{l}\text { As long as antennal } \\
\text { pedicel + first } \\
\text { flagellomere, as } \\
\text { wide as first } \\
\text { flagellomere, } \\
\text { roundly } \\
\text { demarcated below } \\
\text { (Fig. S1E) }\end{array}$ & $\begin{array}{l}\text { Shorter than } \\
\text { antennal pedicel + } \\
\text { first flagellomere, } \\
\text { as wide as first } \\
\text { flagellomere, } \\
\text { truncately } \\
\text { demarcated below } \\
\text { (Fig. S1F) }\end{array}$ \\
\hline $\begin{array}{l}\text { Number of } \\
\text { supracervical setae } \\
\text { per side }\end{array}$ & 2-4 (Fig. S1G) & 3-5 (Fig. S1H) & 4-7 (Fig. S1I) \\
\hline $\begin{array}{l}\text { Number of } \\
\text { pseudotracheae per } \\
\text { side in labellum }\end{array}$ & $\begin{array}{l}\text { 16-18 (West Java), } \\
12-15 \text { (West } \\
\text { Sumatra) }\end{array}$ & $16-17$ & $12-13$ \\
\hline $\begin{array}{l}\text { Number of rows of } \\
\text { acrostichal setulae } \\
\text { around anterior and } \\
\text { extra dorsocentral } \\
\text { setae }\end{array}$ & ( & 4 & 2 \\
\hline $\begin{array}{l}\text { Density of heavy, } \\
\text { peg-like setae on } \\
\text { distal portion of } \\
\text { costa }\end{array}$ & Dense (Fig. S1J) & Sparse (Fig. S1K) & Dense (Fig. S1L) \\
\hline Paramere & $\begin{array}{l}\text { Broader than } \\
\text { aedeagal basal } \\
\text { process (Fig. S1M) }\end{array}$ & $\begin{array}{l}\text { As narrow as } \\
\text { aedeagal basal } \\
\text { process (Fig. S1N) }\end{array}$ & $\begin{array}{l}\text { As narrow as } \\
\text { aedeagal basal } \\
\text { process (Fig. S1O) }\end{array}$ \\
\hline $\begin{array}{l}\text { Ventrosubapical } \\
\text { margin of aedeagus }\end{array}$ & $\begin{array}{l}\text { Slightly notched } \\
\text { and/or finely serrated } \\
\text { (Fig. S1M) }\end{array}$ & Smooth (Fig. S1N) & $\begin{array}{l}\text { Coarsely serrated } \\
\text { (Fig. S1O) }\end{array}$ \\
\hline
\end{tabular}

* Including the holotype. 
Table S4. Morphological comparison of the three forms of Colocasiomyia heterodonta.

\begin{tabular}{|c|c|c|c|}
\hline Form & $I^{*}$ & II & III \\
\hline Distribution & $\begin{array}{l}\text { West Java, West } \\
\text { Sumatra }\end{array}$ & Sarawak, Sabah & $\begin{array}{l}\text { Mt. Kerinci in Jambi } \\
\text { (Sumatra) }\end{array}$ \\
\hline $\begin{array}{l}\text { Antennal first } \\
\text { flagellomere }\end{array}$ & $\begin{array}{l}\text { Approximately } 1.5 \\
\text { times as long as } \\
\text { pedicel (Fig. S2A) }\end{array}$ & $\begin{array}{l}\text { Approximately } 1.5 \\
\text { times as long as } \\
\text { pedicel (Fig. S2G) }\end{array}$ & $\begin{array}{l}\text { Twice as long as } \\
\text { pedicel (Fig. S2M) }\end{array}$ \\
\hline Facial carina & $\begin{array}{l}\text { Much shorter than } \\
\text { antennal pedicel + first } \\
\text { flagellomere, as wide as } \\
\text { first flagellomere (Fig. } \\
\text { S2B) }\end{array}$ & $\begin{array}{l}\text { Slightly shorter than } \\
\text { antennal pedicel }+ \\
\text { first flagellomere, } \\
\text { slightly narrower than } \\
\text { first flagellomere (Fig. } \\
\text { S2H) }\end{array}$ & $\begin{array}{l}\text { Much shorter than } \\
\text { antennal pedicel + first } \\
\text { flagellomere, as wide } \\
\text { as first flagellomere } \\
\text { (Fig. S2N) }\end{array}$ \\
\hline $\begin{array}{l}\text { Number of } \\
\text { pseudotracheae per } \\
\text { side in labellum }\end{array}$ & $11-12$ & $11-12$ & $13-14$ \\
\hline $\begin{array}{l}\text { Long spine on foreleg } \\
\text { tarsomere II }\end{array}$ & $\begin{array}{l}\text { Not reaching to tip of } \\
\text { tarsomere IV (Fig. S2C) }\end{array}$ & $\begin{array}{l}\text { Reaching almost to tip } \\
\text { of tarsomere IV (Fig. } \\
\text { S2I) }\end{array}$ & $\begin{array}{l}\text { Not reaching to tip of } \\
\text { tarsomere IV (Fig. } \\
\text { S2O) }\end{array}$ \\
\hline $\begin{array}{l}\text { Number of small, } \\
\text { tooth-like spines on } \\
\text { foreleg tarsomere II }\end{array}$ & $12-40$ (Fig. S2D) & 11-20 (Fig. S2J) & ca. 31 (Fig. S2O) \\
\hline Paramere & $\begin{array}{l}\text { Obliquely truncate } \\
\text { apically (Fig. S2F) }\end{array}$ & $\begin{array}{l}\text { Obliquely truncate } \\
\text { apically (Fig. S2L) }\end{array}$ & $\begin{array}{l}\text { Extended at } \\
\text { apicolateral corner } \\
\text { (Fig. S2P) }\end{array}$ \\
\hline Aedeagus & $\begin{array}{l}\text { Shorter than } 1 / 2 \\
\text { apodeme (Fig. S2F) }\end{array}$ & $\begin{array}{l}\text { Shorter than } 1 / 2 \\
\text { apodeme (Fig. S2L) }\end{array}$ & $\begin{array}{l}\text { Approximately half as } \\
\text { long as apodeme (Fig. } \\
\text { S2Q) }\end{array}$ \\
\hline $\begin{array}{l}\text { Aedeagal, basal, } \\
\text { beak-like projection }\end{array}$ & $\begin{array}{l}\text { As long as aedeagus } \\
\text { proper, gently curved } \\
\text { (Fig. S2F) }\end{array}$ & $\begin{array}{l}\text { As long as aedeagus } \\
\text { proper, gently curved } \\
\text { (Fig. S2L) }\end{array}$ & $\begin{array}{l}\text { As long as aedeagus } \\
\text { proper, strongly } \\
\text { curved (Fig. S2Q) }\end{array}$ \\
\hline
\end{tabular}

\footnotetext{
* Including the holotype.
} 

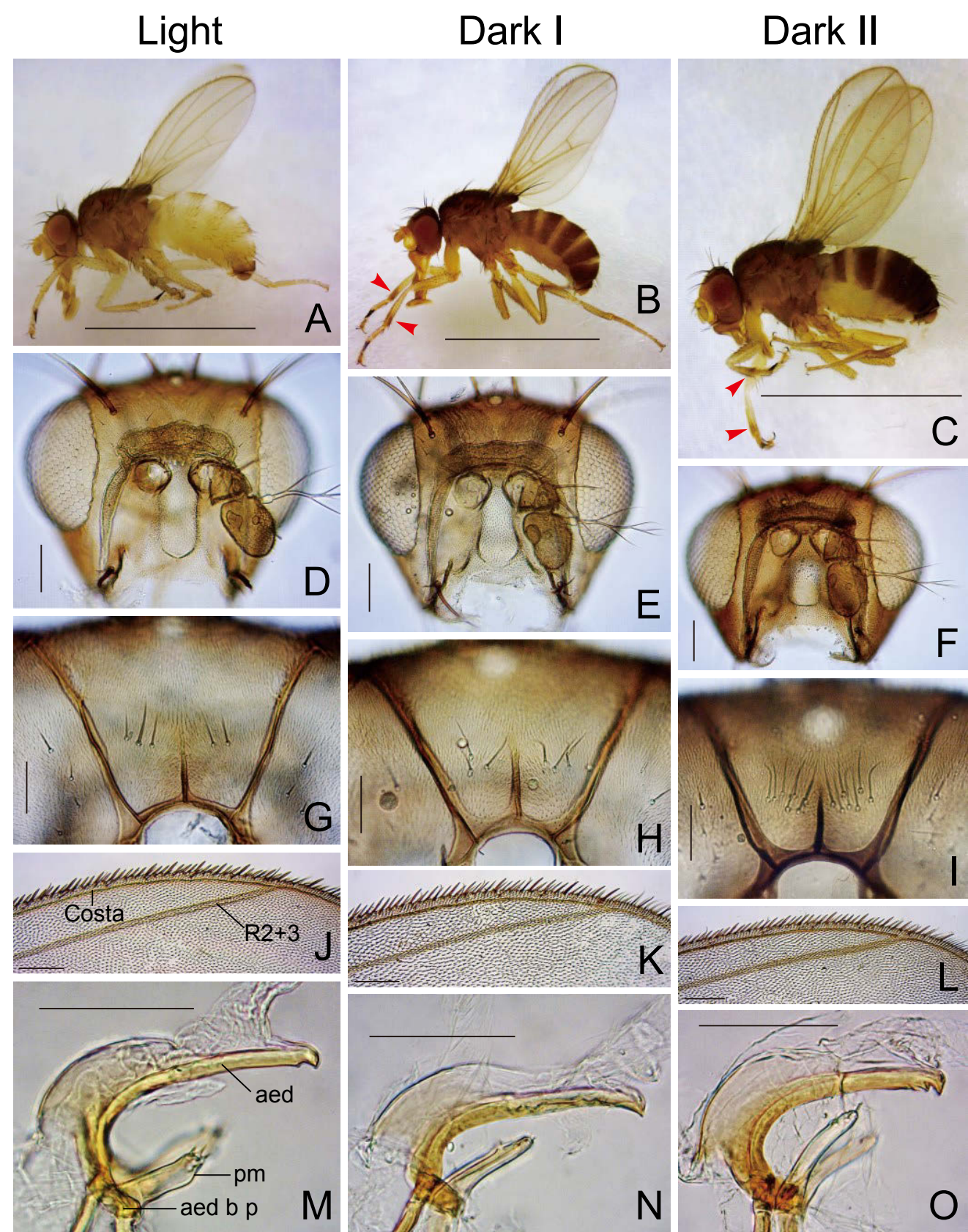

Fig. S1. Morphological differences in the body colour $(\mathrm{A}-\mathrm{C}$; dark patch on apical portion of foreleg tibia indicated with arrowhead), the facial carina (D-F), the number of supracervical setae on the occiput $(\mathrm{G}-\mathrm{I})$, the setation on the costa $(\mathrm{J}-\mathrm{L})$, and the paramere and the aedeagus ( $\mathrm{M}-\mathrm{O}$ ) of the three forms, Light ( $\circlearrowright$ from the type locality, i.e., Bogor Botanical Garden, Bogor, West Java, Indonesia), Dark I (B, K, N: đ from Lembah Anai, West Sumatra, Indonesia; E, H: $\widehat{\delta}$ from Batangang, Padanpanjang, West Sumatra, Indonesia) and Dark II (C, L, O: $\widehat{\jmath}$, F, I: + from Toraut, North Sulawesi, Indonesia), of Colocasiomyia xanthogaster. Abbreviations: aed $=$ aedeagus, aed $b \mathrm{p}=$ aedeagal basal process, $\mathrm{pm}=$ paramere. Scale bars: $0.1 \mathrm{~mm}$. 


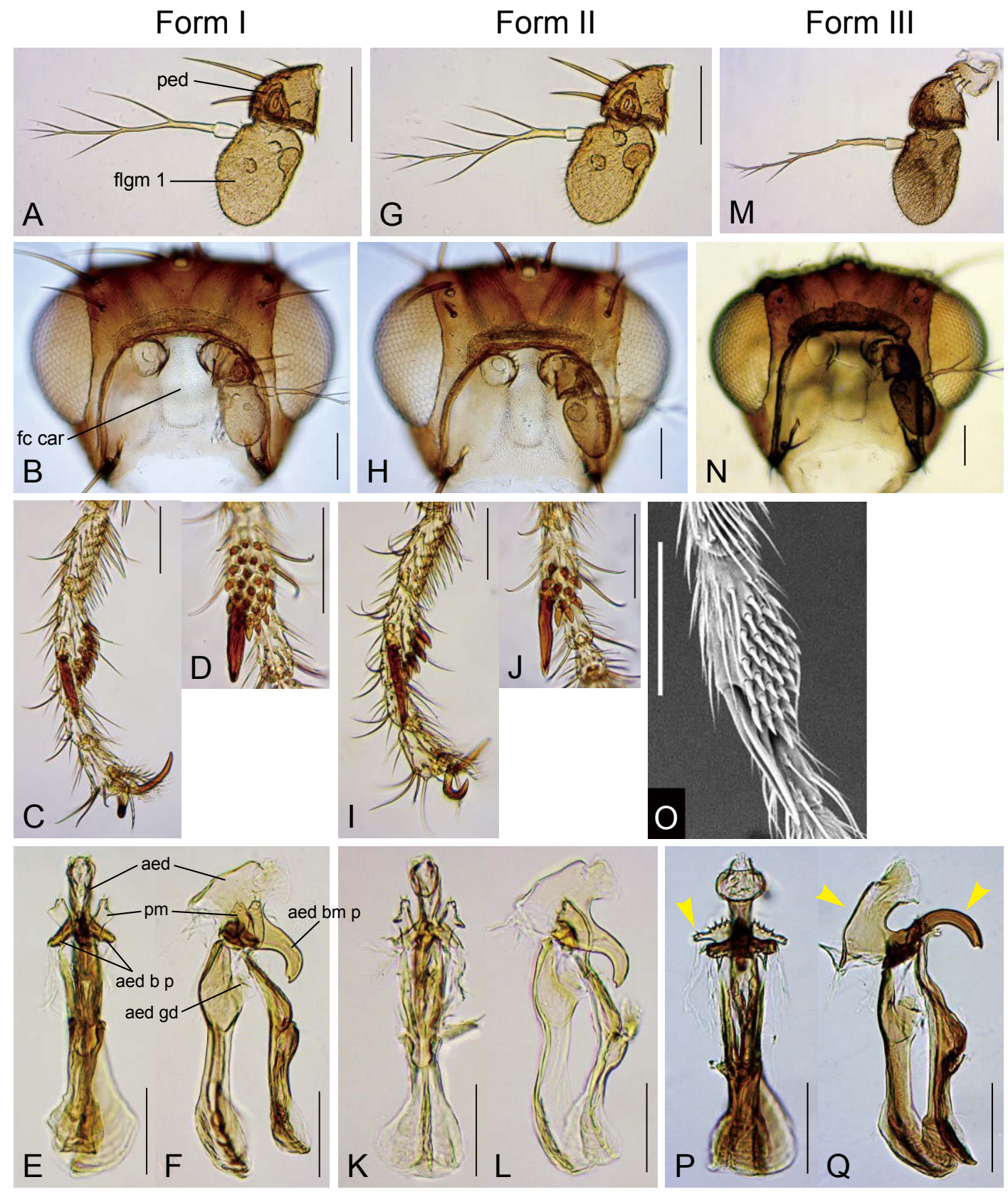

Fig. S2. Morphological differences in the antenna (A, G, M), the facial carina $(B, H, N)$, the pegs on the foreleg tarsomere II (C, D, I, J, O) and the phallic organs (E, F, K, L, P, Q) of the three forms, Form I (A-F: 0 from the type locality, i.e., Bogor Botanical Garden, Bogor, West Java, Indonesia), Form II (G-L: đ from Inobong, Crocker Range, Sabah, Malaysia) and Form III (M-Q: $\widehat{\jmath}$ from Mt. Kerinci, Jambi, Sumatra, Indonesia; distinct characters are shown with yellow arrowheads), of Colocasiomyia heterodonta. Abbreviations: aed $=$ aedeagus, aed $\mathrm{b} p=$ aedeagal basal process, aed $\mathrm{bm} p=$ aedeagal basomedial projection, aed $\mathrm{gd}=$ aedeagal guide, $\mathrm{fc}$ car $=$ facial carina, $\mathrm{pm}=$ paramere . Scale bars: $0.1 \mathrm{~mm}$. 


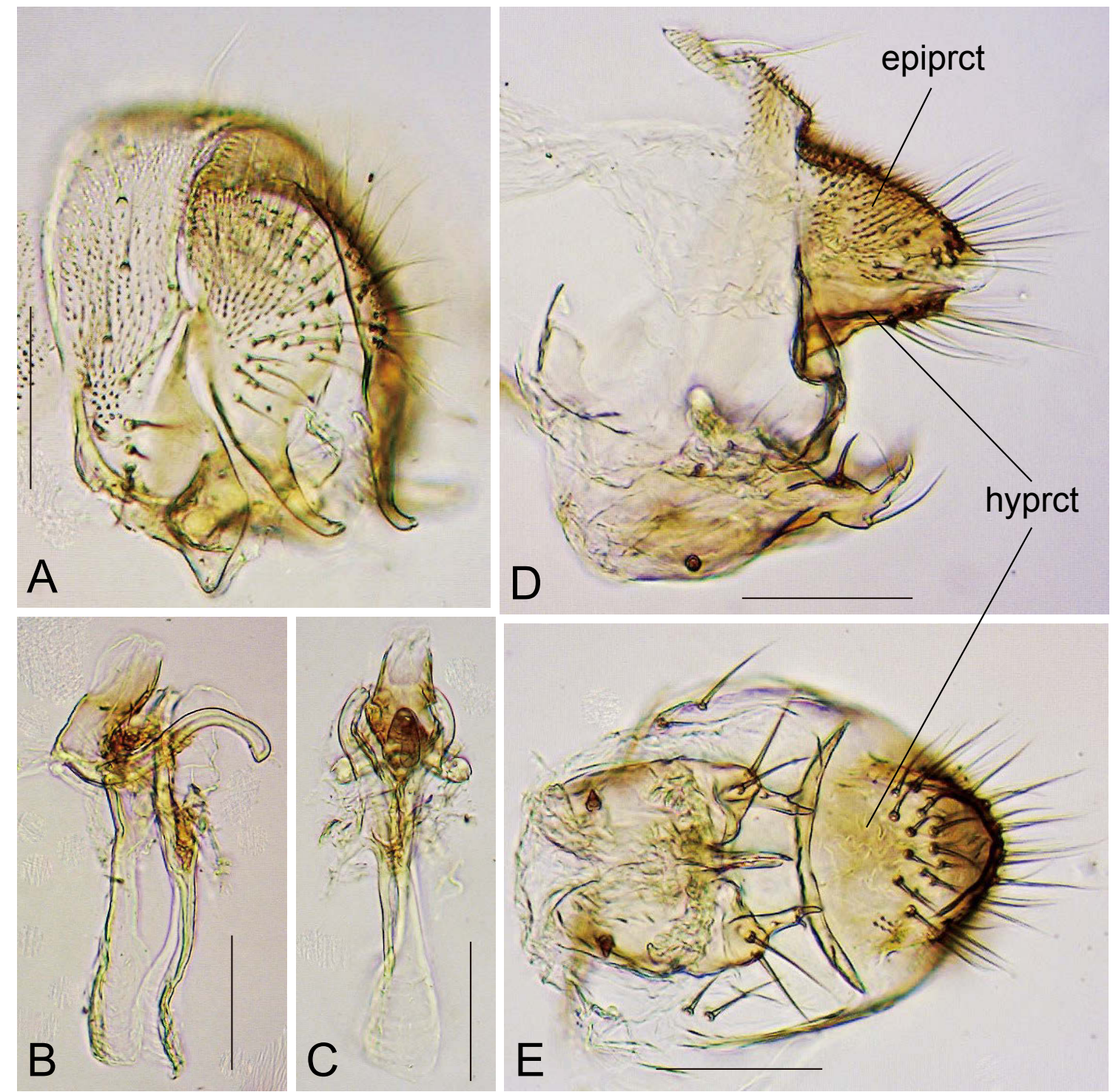

Fig. S3. Microphotographs of the male (A, periphallic organs in caudolateral view; B, phallic organs in lateral view; $\mathrm{C}$, ditto in ventral view) and female (D, lateral view; $\mathrm{E}$, ventral view) terminalia of Colocasiomyia rostrata sp. n. Abbreviations: epiproct $=$ epiproct, hyproct $=$ hypoproct. Scale bars: $0.1 \mathrm{~mm}$. 


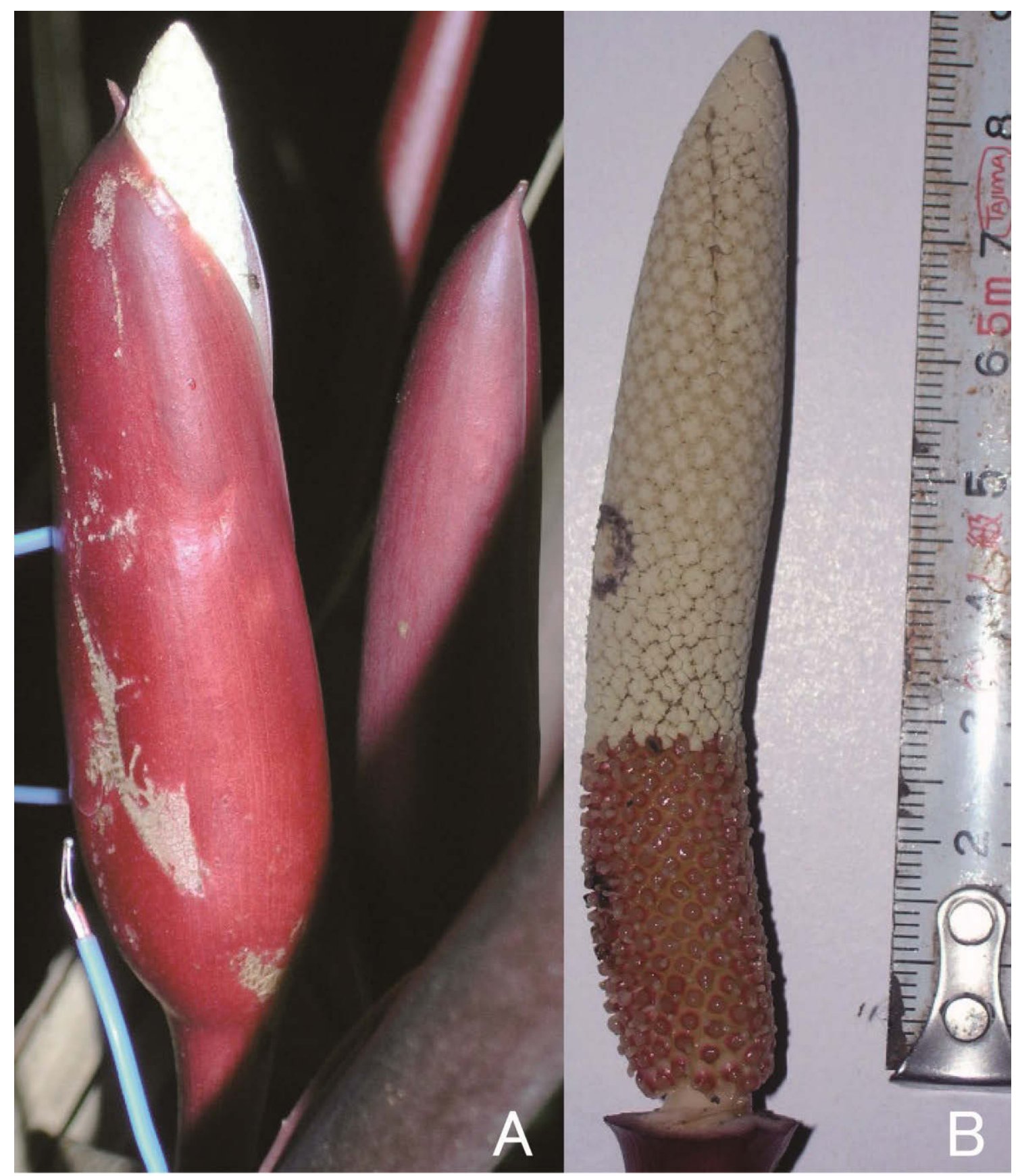

Fig. S4. Inflorescences of Homalomena pendula (Blume) Bakh.f. in the Bogor Botanical Garden, West Java. A, The flowering inflorescence (left) of which thermogenesis was recorded and an inflorescence bud (right); B, the spadix of the former, the spathe having been removed. 


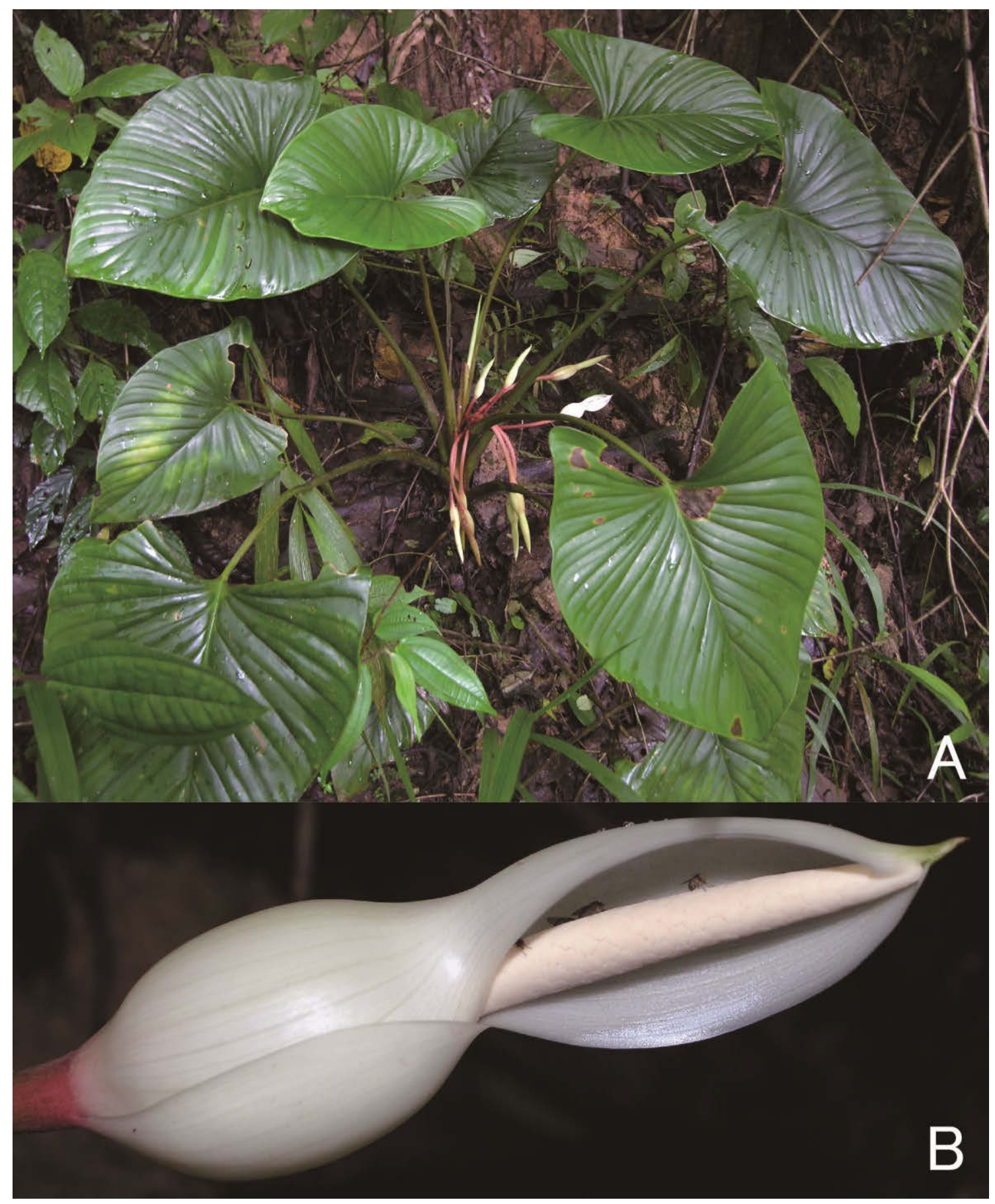

Fig. S5. Homalomena sp.PT (the Hanneae group) at a location between Sungai Penuh and Tapan, West Sumatra, photographed on 7.xii.2004. A, An overview of the plant; B, an inflorescence before pollen release at Stage II, with Colocasiomyia flies on the spadix. 


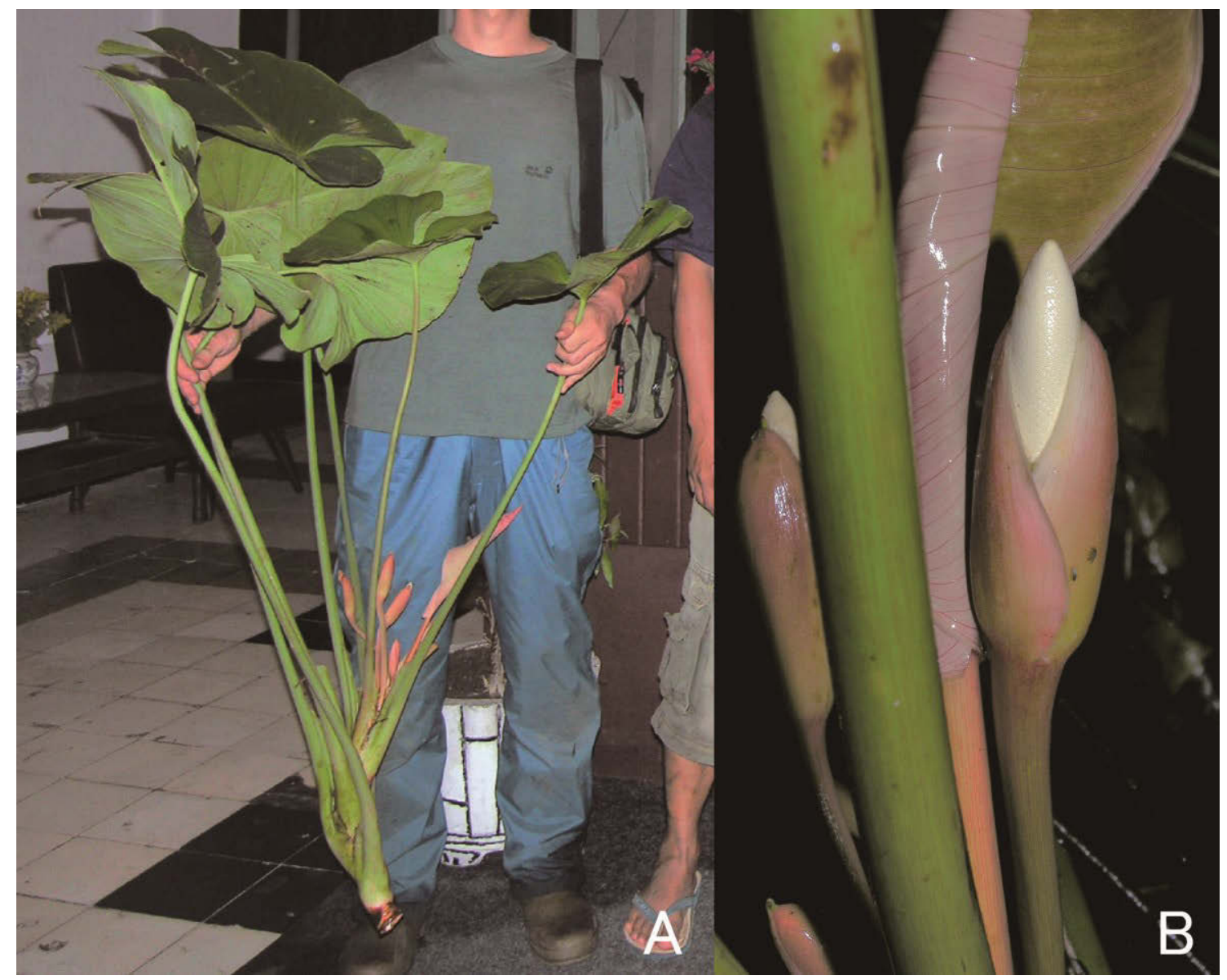

Fig. S6. Homalomena sp.L c.f. megalophylla in Lembah Anai, West Sumatra, photographed on 9.xii.2004. A, An overview of the plant; B, an inflorescence (right) presumably just before the spathe opening at Stage I, with Colocasiomyia flies on the spathe. 


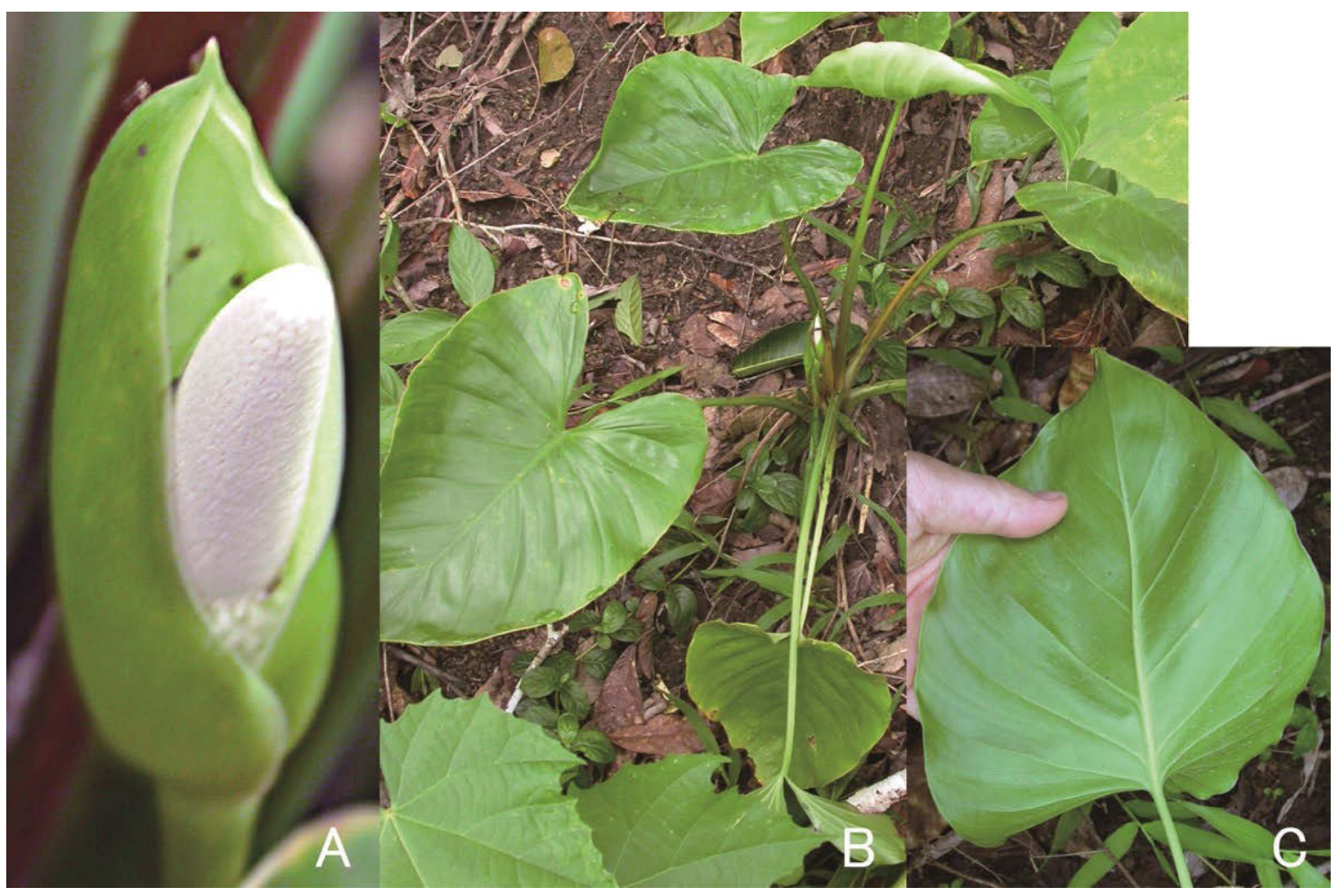

Fig. S7. Homalomena sp. aff. alba (the Homalomena section) in Tumokang, Dumoga Bone National Park, North Sulawesi, photographed on 21.xii.2003. A, An inflorescence at Stage II, with Colocasiomyia flies on the spathe; B, an overview of the plant; C, the underside of a leaf. 


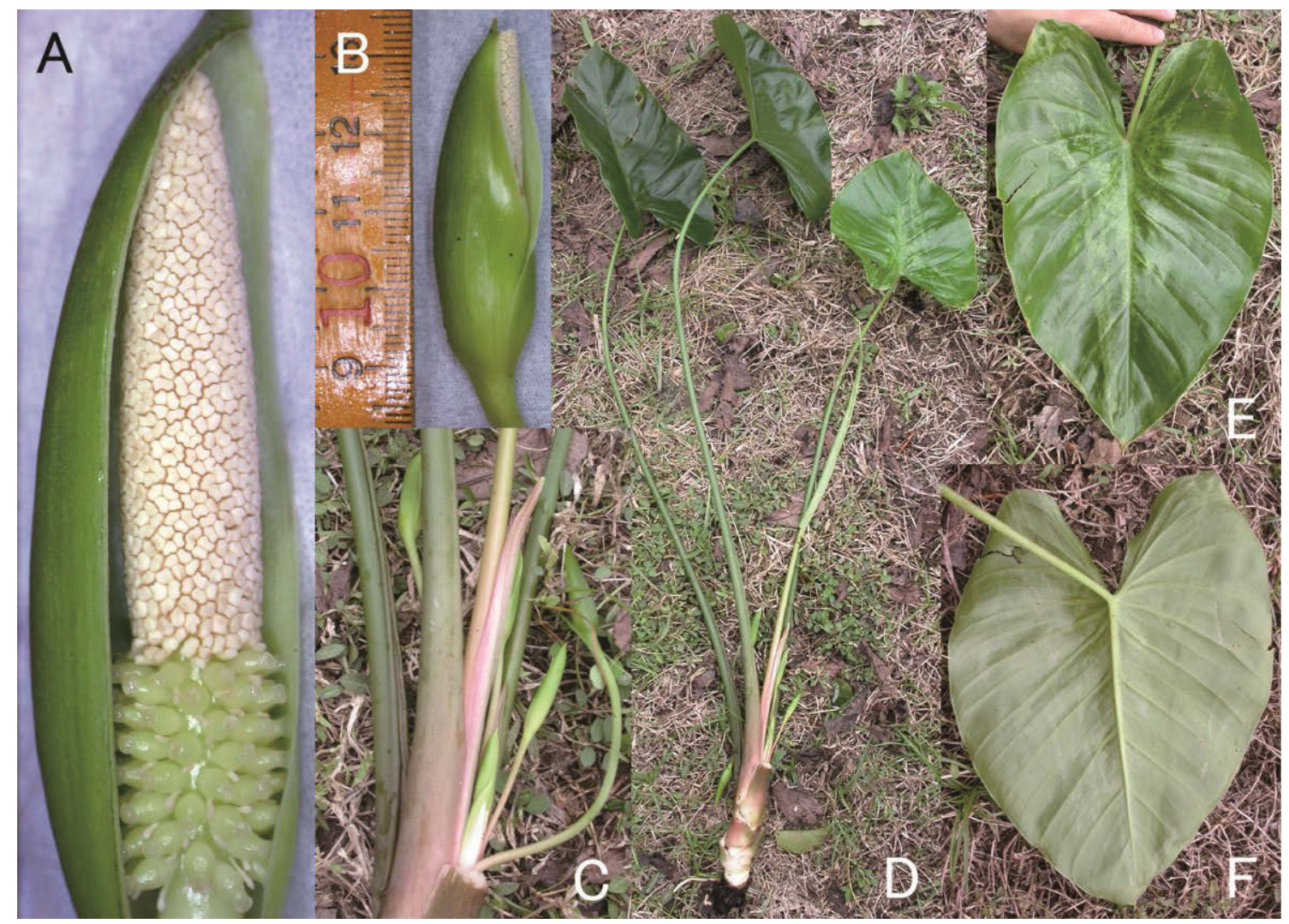

Fig. S8. Homalomena sp.T (the Homalomena section) in Toraut, North Sulawesi, photographed on 19.xii.2003. A, An inflorescence at Stage II, with the spathe partly removed; B, an inflorescence at Stage II; C, a cluster of inflorescences/infructescences sequentially blooming/having bloomed; D, an overview of the plant; $\mathrm{E}$, the upperside of a leaf; $F$, the underside of a leaf. 


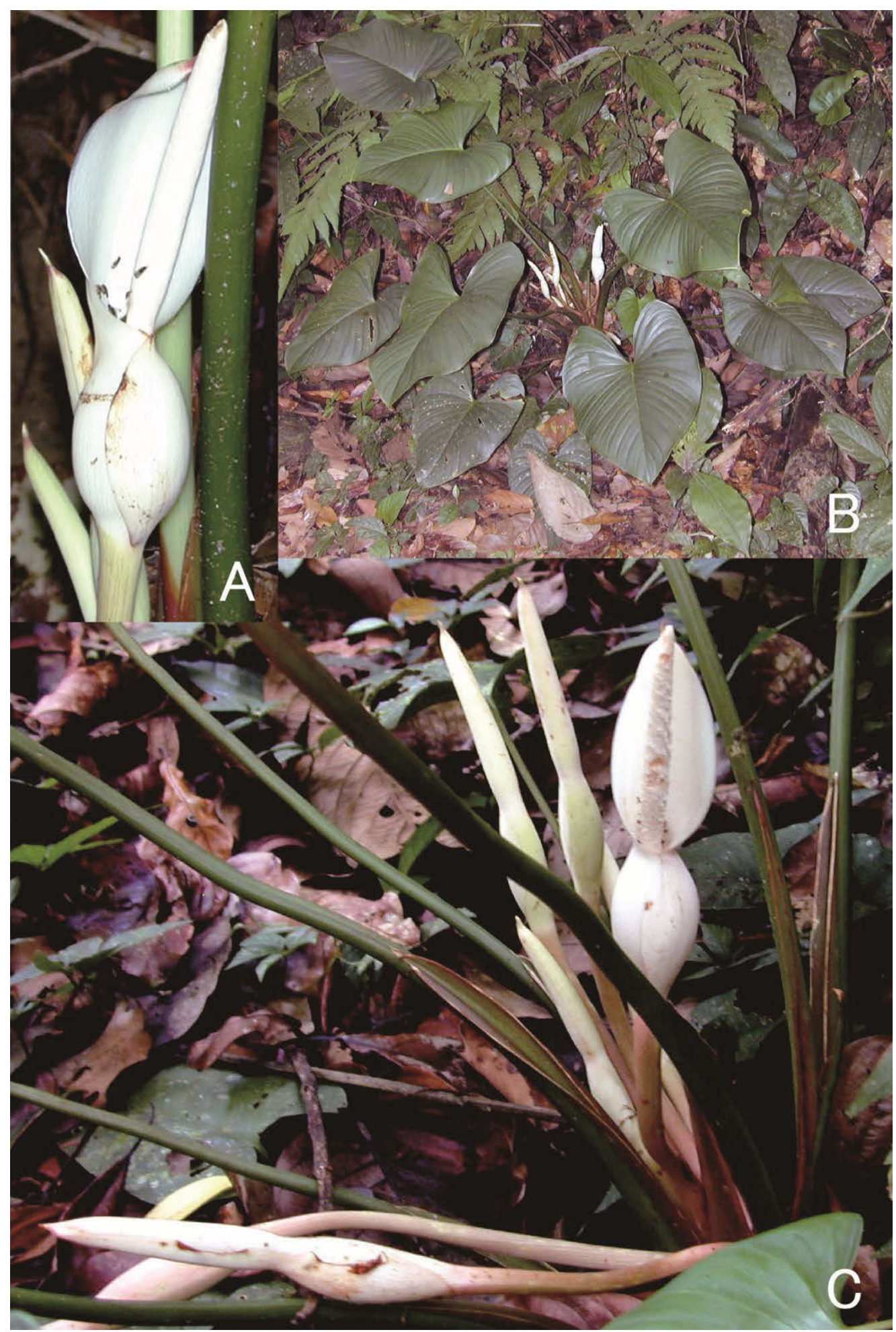

Fig. S9. Homalomena sp.P (the Hanneae group) belonging to the Hanneae complex in Poring, Mt. Kinabalu, Sabah, photographed on 11.iii.2000. A, An inflorescence at Stage II, with Colocasiomyia flies on the spadix; B, an overview of the plant; C, a cluster of inflorescences/infructescences sequentially blooming/having bloomed. 


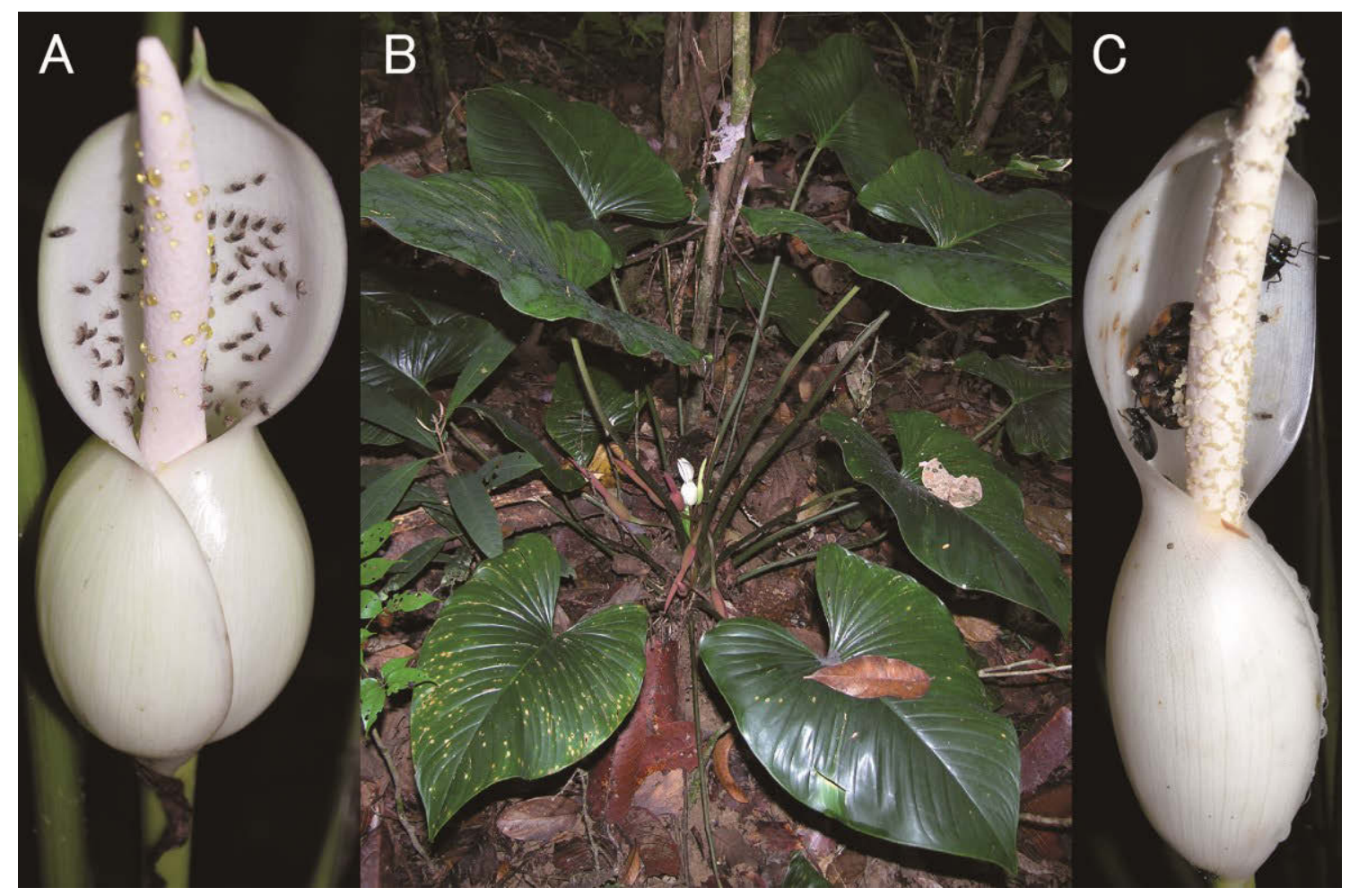

Fig. S10. Homalomena lambirensis S.Y.Wong \& P.C.Boyce in the Lambir Hills National Park, Sarawak, photographed on 17.xi.2004. A, An inflorescence before pollen release at Stage II, with Colocasiomyia nigricauda flies on the spathe and resin droplets excreted on the spadix; B, an overview of the plant; C, an inflorescence after pollen release at Stage II, with C. nigricauda flies on the spathe and spadix, mating Parastasia bimaculata (Scarabaeidae) beetles on the spadix, and Dercetina sp. (Chrysomelidae) beetles on the spathe. 


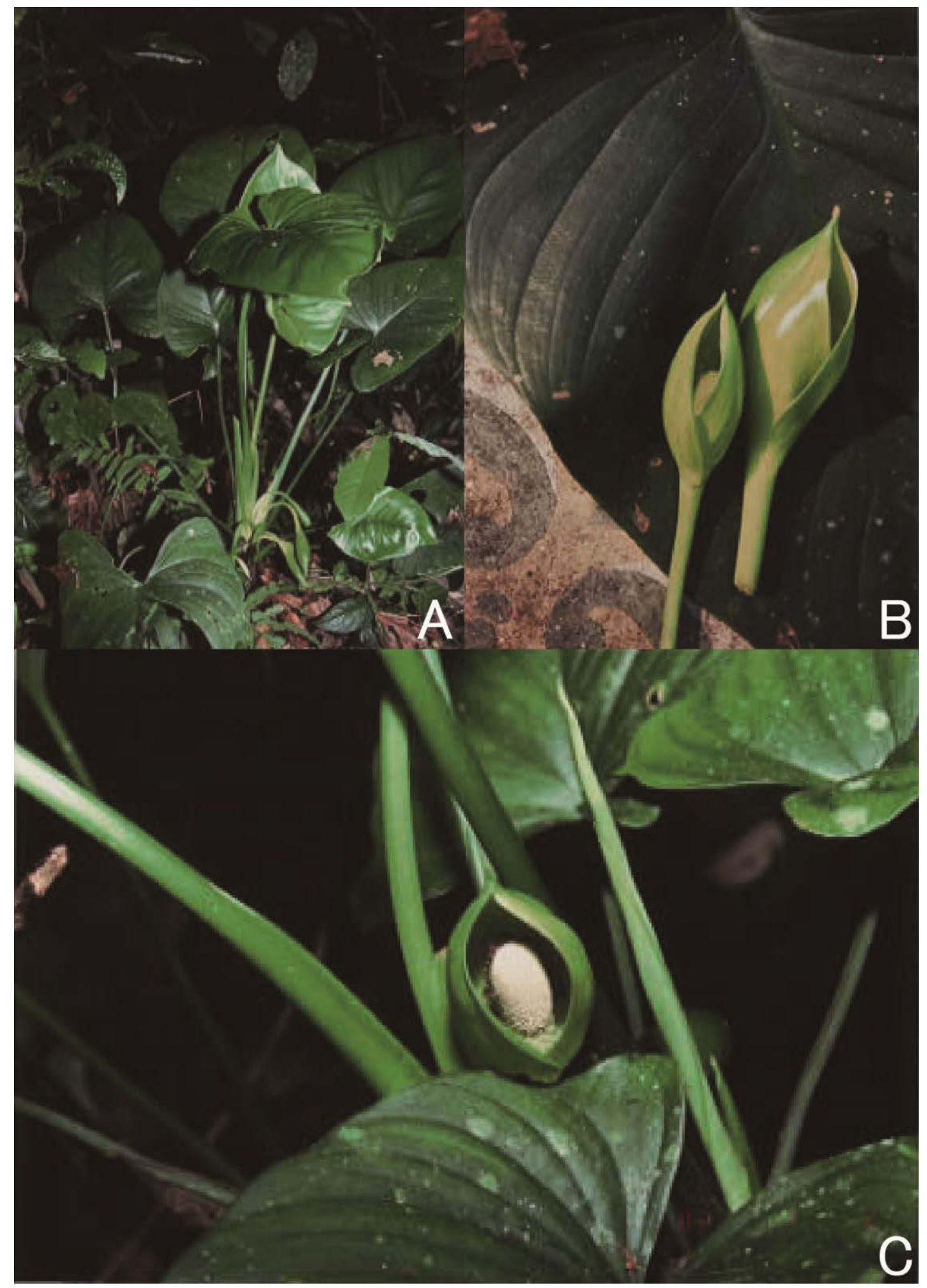

Fig. S11. Homalomena vietnamensis Bogner \& V.D.Nguyen in Cuc Phuong, Vietnam. A, An overview of the plant; B, collected inflorescences and a leaf; C, an inflorescence at Stage II, with Colocasiomyia erythrocephala flies on the spadix. 


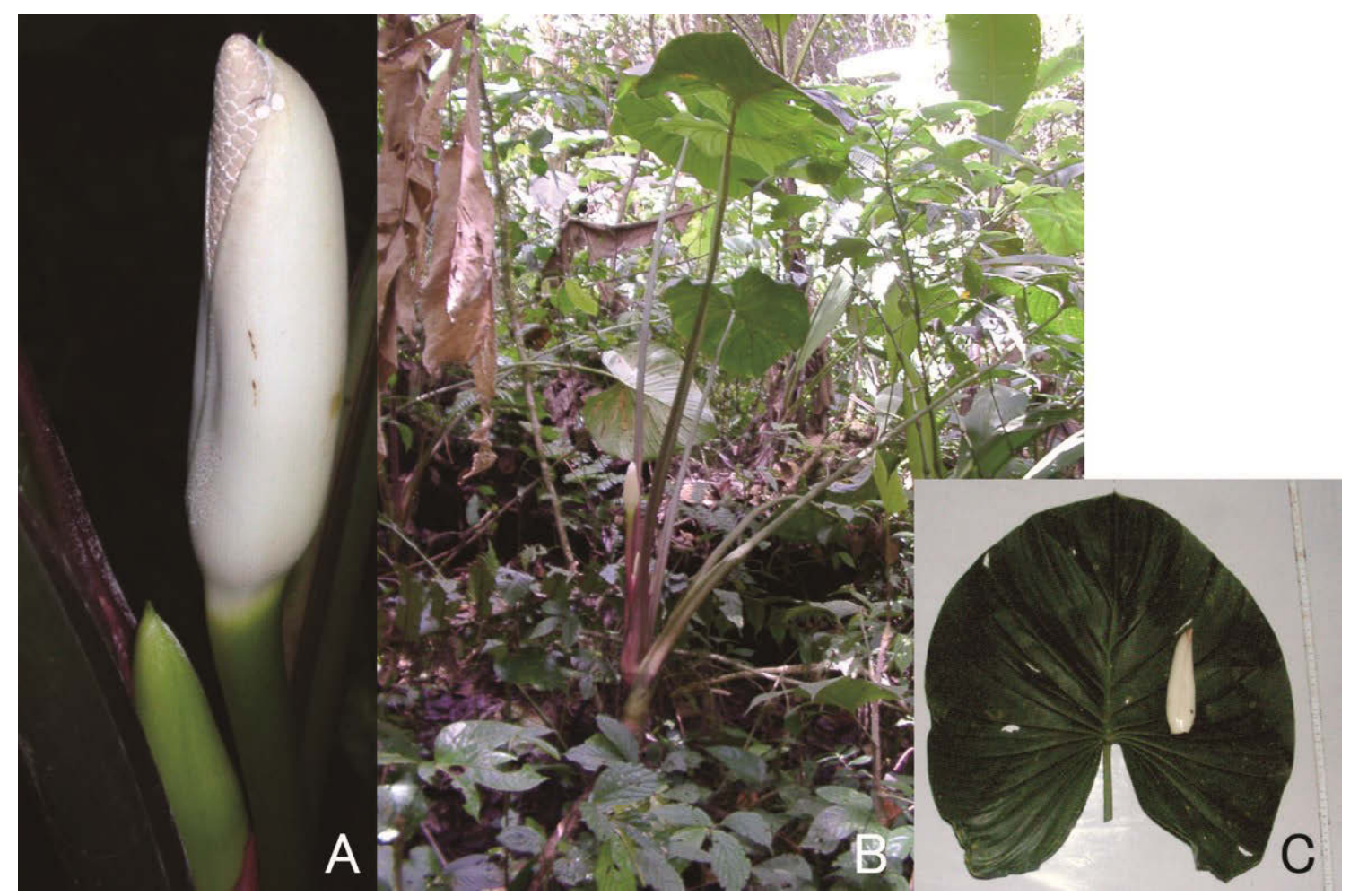

Fig. S12. Homalomena sp.K (the Homalomena section) on Mt. Kerinci, Jambi, Sumatra, photographed on 7.x.2004. A, An inflorescence at Stage III (right) with powdery pollen grains on the spadix, and an inflorescence bud; B, an overview of the plant; C, a collected inflorescence and a leaf. 


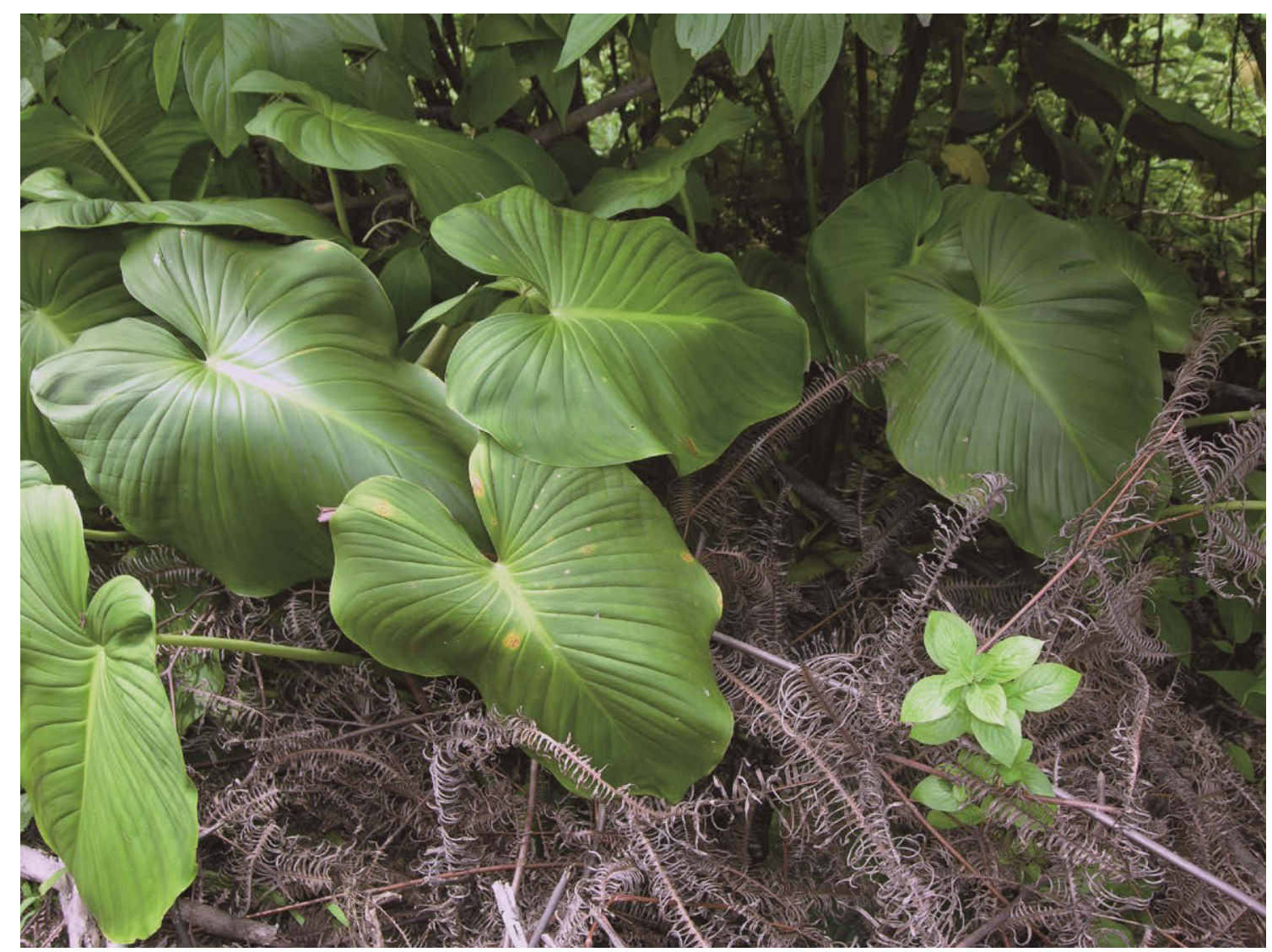

Fig. S13. Homalomena sp.BP in Bukit Punai, West Sumatra, photographed on 8.xii. 2004. 